NBER WORKING PAPER SERIES

\title{
THE RELEVANCE OF BROKER NETWORKS FOR INFORMATION DIFFUSION IN THE STOCK MARKET
}

\author{
Marco Di Maggio \\ Francesco Franzoni \\ Amir Kermani \\ Carlo Sommavilla \\ Working Paper 23522 \\ http://www.nber.org/papers/w23522 \\ NATIONAL BUREAU OF ECONOMIC RESEARCH \\ 1050 Massachusetts Avenue \\ Cambridge, MA 02138 \\ June 2017
}

We thank John Campbell, Lauren Cohen, Alex Edmans, Laurent Fresard, Gary Gorton, Nicholas Hirschey, Paul Irvine, Owen Lamont, Andrew Lo, Leonid Kogan, Peter Kondor (discussant), Marcin Kacperczyk, Marco LiCalzi, Alan Moreira, Toby Moskowitz, Tyler Muir, Shrihari Santosh (discussant), Andrei Shleifer, Emil Siriwardane, Erik Stafford, Elvira Sojli (discussant), Steve Ross, Laura Veldkamp (discussant), Annette Vissing-Jorgensen, Johan Walden, Haoxiang Zhu, and seminar participants at the NBER conference on New Developments in Long-Term Asset Management, 2017 American Finance Association, the FRBNY/NYU Conference on Financial Intermediation, Harvard-MIT joint finance conference, Smith School of Business (U. of Maryland), University of Chicago (Booth), New York University (Stern), Boston University (Questrom), the London School of Economics, the London Business School, MIT (Sloan), University of Berkeley (Haas),Warwick Business School, the Security and Exchange Commission, AQR, Arrowstreet Capital, and Point72 for helpful comments. The views expressed herein are those of the authors and do not necessarily reflect the views of the National Bureau of Economic Research.

NBER working papers are circulated for discussion and comment purposes. They have not been peer-reviewed or been subject to the review by the NBER Board of Directors that accompanies official NBER publications.

(C) 2017 by Marco Di Maggio, Francesco Franzoni, Amir Kermani, and Carlo Sommavilla. All rights reserved. Short sections of text, not to exceed two paragraphs, may be quoted without explicit permission provided that full credit, including $\odot$ notice, is given to the source. 
The Relevance of Broker Networks for Information Diffusion in the Stock Market

Marco Di Maggio, Francesco Franzoni, Amir Kermani, and Carlo Sommavilla

NBER Working Paper No. 23522

June 2017

JEL No. G12,G14,G24

\begin{abstract}
$\underline{\text { ABSTRACT }}$
This paper shows that the network of relationships between brokers and institutional investors shapes the information diffusion in the stock market. We exploit trade-level data to show that central brokers gather information by executing informed trades, which is then leaked to their best clients. We show that after large informed trades, a significantly higher volume of other institutional investors execute similar trades through the same broker, allowing them to capture higher returns in the first few days after the initial trade. In contrast, we find that when the informed asset manager is affiliated with the broker, such imitation does not occur. Similarly, we show that the clients of the broker employed by activist investors to execute their trades tend to buy the same stocks just before the filing of the 13D. This evidence also suggests that an important source of alpha for fund managers is the access to better connections rather than superior skill.
\end{abstract}

Marco Di Maggio

Harvard Business School

Baker Library 265

Soldiers Field

Boston, MA 02163

and NBER

mdimaggio@hbs.edu

Francesco Franzoni

Swiss Finance Institute

Via G. Buffi 13

6904, Lugano - Switzerland

and University of Lugano

francesco.franzoni@usi.ch
Amir Kermani

Haas School of Business

University of California, Berkeley

545 Student Services Building \#1900

Berkeley, CA 94720

and NBER

kermani@berkeley.edu

Carlo Sommavilla

Swiss Finance Institute \& USI,

Via G. Buffi 13 - CH 6900 - Lugano

carlo.sommavilla@usi.ch 


\section{Introduction}

How information is generated by market participants, disseminated, and finally incorporated into prices has been the subject of extensive literature in financial economics, and remains one of the key questions for understanding how financial markets operate. Theoretical contributions on this topic date back to at least Grossman and Stiglitz (1980) and Kyle (1985); they have mainly focused on the strategic interaction between informed and uninformed traders. However, this interaction is far from happening in a vacuum, as financial markets are characterized by layers of intermediation and by a network of relations in which investors operate. Specifically, institutional investors routinely make use of brokers to execute their trades, and the brokers' role in disseminating the information that they acquire from their clients is at best unclear. The brokers' practice of selling order flow and the regulatory scrutiny about potential information leakage provide anecdotal evidence for the conjecture that brokers play a pivotal role in directing the information flow in the market. ${ }^{1}$ This paper shows that brokers indeed play a key role in shaping information diffusion in the stock market.

Although information about prices is readily disseminated in equity markets, brokers' vantage point might allow them to extrapolate the informational content of an order and to anticipate the future behavior of prices. Moreover, some brokers have easier access to information than others. In particular, central brokers - those that are pivotal in the network trading relations - are in a better position to observe the informational flow than peripheral ones. Then, brokers might have an incentive to extract these informational rents by communicating and spreading the information to their clients.

These considerations raise the question of how the network of relationships between brokers and investors influences market outcomes. Specifically, are the investors trading through central brokers able to generate higher returns thanks to their superior access to order flow information? What role do brokers have in affecting how information is incorporated into prices? This paper investigates these questions exploiting institutional trade-level data, which provide information

\footnotetext{
${ }^{1}$ Recently, Credit Suisse and Citi were accused of leaking information about customer orders to other market participants (see, for instance, http://www.nytimes.com/2016/02/02/business/dealbook/regulators-arent-done-withdark-pool-investigations.html? r=0).
} 
on the trades submitted by a significant sample of fund managers, including the identity of the broker intermediating the trades.

We motivate our analysis by providing results showing that trades channeled through central brokers earn significantly positive abnormal returns. Intuitively, if brokers have access to better information, the trades they intermediate should be, on average, more profitable. Our strategy is twofold. First, we construct monthly portfolios based on brokers' centrality. One advantage of this methodology is the ability to report the economic significance of the brokers' centrality for investors in a transparent way. We compute the monthly returns of the high-minus-low centrality portfolio and regress them on common risk factors such as the market excess return, SMB, HML, and the momentum factor. We find that this portfolio generates a significant alpha of about forty basis points per month.

A potential concern is that brokers that are more central in the network also differ in other important characteristics from less central brokers; for instance, one could imagine better managers being more likely to trade with central brokers, or central brokers being specialized in more illiquid stocks. To address these concerns, our second set of results takes advantage of the depth of our data. We find that trades channeled by central brokers tend to outperform those made through the peripheral ones, even when we consider the same stock traded by the same manager in the same timeframe, i.e. controlling for stock-manager-time fixed effects. This evidence strongly suggests that the main results are not fully explained by the fact that different brokers might trade stocks with different characteristics. ${ }^{2}$

Having established that trades executed through more central brokers generate abnormal returns, which are not explained away by controlling for managers, stocks or brokers characteristics, we investigate the source of these returns. Our tests are inspired by the recent theoretical studies of Babus and Kondor (2013) and Yang and Zhu (2016) that suggest a potential channel: by observing a larger and more informed order flow, central brokers can learn faster from the transactions they execute. ${ }^{3}$ In other words, when an informed trader submits an

\footnotetext{
${ }^{2}$ Furthermore, network centrality goes above and beyond capturing the size of the broker, as measured by the volume that it intermediates. In fact, we control for the total volume of the trades intermediated by each broker without affecting our findings. We also show that differences in trade execution between central and peripheral brokers cannot explain our results.

${ }^{3}$ Farboodi and Veldkamp (2017) provide a long run growth model where traders have the option to extract information from order flow data mining, and study the implication for price informativeness and market liquidity.
} 
order through a broker, the broker can then exploit its informational rent by disseminating this information to other clients, who would then earn higher returns by imitating the informed trader strategy.

This information channel has several implications, which we formally test. The first implication is that, if central brokers disseminate the information contained in informed trades, uninformed traders should behave similarly to the informed ones. To test this hypothesis, we identify informed trades in two ways. First, we investigate large trades executed by hedge funds (originators): we find that these large trades are profitable and anticipate a move of asset prices that is not followed by a reversal even after several months, which strongly suggests that these are indeed informed trades. Second, we focus on the trades executed by activist investors as reported on their 13D forms, and analyze the trading strategies of the other clients of the broker employed by the activist before the $13 \mathrm{D}$ is filed.

Our first main result is that other investors (followers) are significantly more likely to trade with the same broker in the same direction of the large informed trade while the broker is still executing the originator's order. We also show similar results for the followers' volume. Furthermore, we show that the followers tend to start reversing their trades after two weeks. This suggests that their decision to trade is more likely to be opportunistic, i.e. exploiting the information passed by the broker, rather than based on long-term views. These effects are more pronounced when the large order goes through a central broker, suggesting that central brokers are more likely to pass along the information about the large trade to other investors.

An additional implication of the information channel is that brokers intermediating the large trades would reduce the occurrence of back running (i.e. the imitation of the informed trade) if the large trader and the broker are part of the same institution. To test this hypothesis, we restrict attention to large trades where the manager has institutional ties with the broker, and we find that the broker preempts the competition by other traders. Then, if this information leakage was only the result of normal market making activities, such as contacting potential counterparties to fill the informed order, we should not observe such heterogeneous effects depending on the identity of the originator.

One concern is that the originator and the followers trade in a correlated fashion because they follow similar styles, as in Barberis and Shleifer (2003), or because they react to the same 
information. To rule out this possibility, we show that our results hold even when we restrict attention to stocks that have not been previously traded by the followers, but that were heavily traded by the originator. In these cases, it is unlikely that the large trader and the followers are tracking similar investment styles. ${ }^{4}$ To further rule out the possibility that traders are reacting to the same public information, we also perform our analysis excluding earnings announcement days as well as days in which equity analysts change their recommendations. We find that our results are indeed not driven by those events.

We also provide two additional placebo tests. First, to corroborate the idea that large trades constitute indeed an "information shock", we estimate our main specification shifting the event date to four weeks before the actual large trade. We find that the correlation between the followers and the originator of the large trade breaks down. This indicates that the observed correlation among traders' strategies is unlikely to be driven by factors other than the large trade itself.

Second, we also check if the followers employ other brokers to imitate the originator's trades. The idea is that if they receive information by the broker executing the large trade, they will compensate him by channeling most of their trades through this same broker in order to pay him most of the commissions. Consistent with this hypothesis, we find that followers concentrate their trades with the broker that executed the large trade, suggesting a mutual exchange of favors among the parties.

The previous results centered on the idea that information is generated by unusually large trades which then percolates through the brokers to other investors. Another natural setting in which we test the information hypothesis is that of activist investors. In fact, activists have to file a 13D form with the SEC within ten days of reaching a 5\% stake in the company they are targeting. Existing works have shown that most of the trades are clustered right around this 5\% threshold (see, among others, Collin-Dufresne and Fos, 2015). Furthermore, activists do not have an incentive to release their intent before they build up their positions as that would create unwanted competition from other traders. In other words, before the 13D filing it is likely that only the broker employed to execute the activist's trades has information about his strategy.

\footnotetext{
${ }^{4}$ Notice that this alternative hypothesis would also need to explain why these managers tend to trade with the same broker, why the best clients and the ones affiliated tend to imitate more strongly, and why the followers tend to revert their trades after a few days.
} 
Then, if brokers were releasing information about their incoming orders, we should expect other traders to buy the stock of the target company before the 13D is filed.

To test this hypothesis, we collected information about the dates and targets from the 13D forms as well as the broker employed by the activist. ${ }^{5}$ We show that other clients of this broker are significantly more likely to buy the stock of the activist's target firm right before the 13D filing, which confirms our information hypothesis. Furthermore, an implication of the information channel is that if brokers have access to superior information, they should release it selectively, in a way that allows them to extract the highest rents. Based on this logic, we should observe that especially the best clients of the central brokers receive the information. The best clients are those with which the broker made more profits in the past and from which it expects to continue to receive business in the future. Accordingly, we measure the strength of the brokermanager relationship in three ways: by the past volume intermediated by the broker for a given manager, by the commission paid by a given manager to the broker, and by the frequency with which the given manager trades with the broker. We find strong evidence that the managers with the strongest relationships with central brokers capture, on average, higher excess returns per trade.

Overall, the previous results have shed light on the source of the advantage for central brokers in generating excess returns by highlighting that they tend to disseminate the information gathered from informed traders. These results raise the question of why an informed asset manager should be willing to give up part of its informational advantage by trading with brokers that tend to leak to other market participants. One potential answer relies on the repeated nature of the trading relationship between broker and asset manager. Specifically, we find that being an informed trader in the past (i.e. information supplier) predicts being a follower in the future (i.e. an information receiver). This suggests that some asset managers are willing to give up some of their advantage because by doing so they make sure to be able to extract rents when other market participants are informed.

Finally, we investigate the price formation process and test whether this behavior by central brokers also affects price informativeness. We document that informed trades lead to faster stock price movement when they are intermediated by central brokers rather than peripheral ones.

\footnotetext{
${ }^{5}$ We are grateful to Vyacheslav Fos for providing the list of activists filing the 13D.
} 
Specifically, we follow DellaVigna and Pollet (2009) and analyze the response ratio to large trades, defined as the ratio between the cumulative Carhart (1997) four-factor adjusted returns on day 5 and day 25 since the large trade. We find that the response ratio increases with the broker centrality, suggesting that prices adjust more quickly after large trades when these are executed through central brokers. Furthermore, we also find that the price is more likely to overshoot for about ten days after the large trade before partially reverting. These results are consistent with our interpretation of the evidence that brokers tend to generate higher volume in the same stock by disseminating information about the large trade to their clients.

Overall, our findings indicate that, although we are analyzing an exchange where prices are public information, and not an OTC market, intermediaries play a key role in the acquisition and dissemination of private information, which they extract from order flow and, more generally, from the interaction with their clients. Since we show that informed traders, the ones placing large trades, are able to capture higher excess returns when they use central brokers, their incentives to produce information are not adversely affected by the brokers' activity, in contrast to what would occur in a model à la Grossman and Stiglitz (1980). Furthermore, by disseminating the information to their best clients, brokers are also making sure that prices incorporate the information faster. This faster revelation of information can be beneficial for, and even encouraged by, the informed trader, as described by Ljungqvist and Qian (2016) and Kovbasyuk and Pagano (2015) in the context of short selling.

Few other recent papers have reexamined the way in which information spreads in financial markets. For instance, Babus and Kondor (2016) have focused on information aggregation when agents trade in a network setting, such as over-the-counter markets. Yang and Zhu (2016) provide a two-period Kyle (1985) model of "back-running," where, in addition to informed and noise traders, there is an investor who learns from the order-flow generated by the informed speculator after the order is filled. Although we analyze data from the stock market, which is a centralized market, these studies provide a fitting background for the empirical work in this paper. In fact, our results provide evidence for the theoretical insights in Babus and Kondor (2016) that more central broker-dealers are able to learn more than peripheral ones, and confirm the idea presented in Yang and Zhu (2016) that traders might back-run informed traders by observing the order-flow, which provides a way for the information to spread in the market. 
Our findings also relate to the papers studying information percolation in financial markets, such as Duffie, Malamud and Manso (2009, 2015), Duffie, Giroux, and Manso (2010), and especially, Andrei and Cujean (2017), who show how information percolation might lead to momentum and reversals. Also related is Walden (2016), who shows that agents who are more closely connected have similar trades in the context of a dynamic noisy rational expectations model, in which information diffuses through a general network of agents. The common feature of these models is that agents exchange information in random, bilateral private meetings but trade in centralized markets. Our paper shows that information percolation might not be driven by random meetings between traders, but rather be conveyed by brokers who gather the information through their trade intermediation and then disseminate it to their clients. ${ }^{6}$

Lately, the study of trading networks has made some forays into the empirical finance literature as well. The recent paper by Di Maggio, Kermani, and Song (2017) studies the network of dealers in the corporate bond market. The authors show that dealers provide liquidity in periods of distress to the counterparties with which they have the strongest ties. However, the paper also gives evidence of the inherent fragility of the network structure as the failure of a core dealer causes the connected dealers to change their pricing functions and to become less profitable. $^{7}$

Other recent papers have studied the role of the network in different markets. For instance, Li and Schürhoff (2014) study the municipal bond market and highlight the tradeoff that investors face: central dealers have higher execution speed, but charge higher spreads; whereas peripheral dealers are less expensive, but slower. Hollifield, Neklyudov, and Spatt (2014), instead, identify a core-periphery network structure in the securitization market and show that pricing appears to be more favorable at the center of the network. Afonso, Kovner, and Schoar (2013) describe the network of relations in the interbank lending market, separating between spot and long-term borrowing transactions. They show that the latter insulate borrowers from liquidity shocks.

\footnotetext{
${ }^{6}$ Our paper is more distantly related to models of learning in arbitrarily connected social networks (see for instance, Acemoglu et al. (2011), Bala and Goyal (1998), Colla and Mele (2010), DeMarzo, Vayanos and Zwiebel (2003), and Golub and Jackson (2010)), and the papers providing evidence that the network structure influences information aggregation in the context of aid programs (Alatas, Banerjee, Chandrasekhar, Hanna, and Olken (2016)), technology adoption (Bandiera and Rasul 2006; Duflo, Kremer, and Robinson 2004; and Conley and Udry 2010) or microfinance, and public health (e.g., Munshi 2003; Bandiera, Barankay, and Rasul 2009; Banerjee et al. 2013; and Kremer and Miguel 2007).

${ }^{7}$ A related work is Gabrieli and Georg (2014), which studies liquidity reallocation in the European interbank market and documents a significant change in the network structure around the bankruptcy of Lehman Brothers.
} 
Finally, Hendershott, Li, Livdan, and Schürhoff (2016) study the transactions of insurance companies with corporate bond dealers and show a tradeoff between order flow concentration and dealer competition for best execution. ${ }^{8}$

All of the existing evidence is for OTC markets, while we analyze the U.S. stock market and provide evidence of the mechanisms through which the network of broker-investors relationships affects returns: information diffusion. Goldstein, Irvine, Kandel, and Wiener (2009), using an earlier version of our data, provide a useful description of the institutional brokerage industry. They show that institutions value long-term relations with brokers. Also, consistent with our results, the best institutional clients are compensated with the allocation of superior information around changes of analyst recommendations.

Our results are also consistent with Li, Mukherjee, and Sen (2016), who show that analysts at brokerage houses with which company insiders place their trades have an informational advantage. Also related are Chung and Kang (2016), who use monthly hedge fund returns to document comovement in the returns of hedge funds sharing the same prime broker, and Ozsoylev, Walden, Yavuz and Bildik (2014), who employ data from the Istanbul Stock Exchange to show that more central individual investors earn higher returns and trade earlier than peripheral investors with respect to information events. A complementary approach to studying how information is shared in the market has recently been proposed by Boyarchenko, Lucca, and Veldkamp (2016), who build a model and calibrate it to the Treasury auction data. ${ }^{9}$

\footnotetext{
${ }^{8}$ Another strand of finance literature that uses concepts drawn from network analysis is concerned with the effect of social networks on different measures of financial behavior. This literature, which is not directly related to the theme of this paper, owes much to the seminal paper by Cohen, Frazzini, and Malloy (2010). The authors show that sellside analysts with school ties to senior corporate officers are able to produce more accurate earnings forecasts. Many are the contributions in this literature and a full review is out of the scope of this paper. For example, Fracassi and Tate (2012) show that firms with more powerful CEOs are more likely to appoint directors with social ties to the CEO, and this behavior harms firm performance. Shue (2013) shows that managers who graduated from the same MBA class share similar managerial decisions. Lerner and Malmendier (2013) argue that a higher share of entrepreneurial peers in the business school class reduces entrepreneurship of a given graduate. Nguyen (2012) shows that when CEO and some of the directors belong to the same social network, the CEO is less likely to be dismissed for poor performance.

${ }^{9}$ The hypothesis that financial intermediaries share order-flow information is supported by Hortacsu and Kastl (2012). They use data from Canadian Treasury auctions to show that dealers learn and share order flow information, and that it also accounts for an important fraction of dealers' surplus.
} 
They use this model to quantify counterfactuals about policy intervention that would ban information sharing between dealers and with clients. ${ }^{10}$

The remainder of the paper is organized as follows. Section 2 describes the data sources and summary statistics and Section 3 presents the motivating evidence that trading through more central brokers leads to higher abnormal returns. Section 4 presents evidence showing that these abnormal returns are mainly generated by the ability of more central brokers to collect and disseminate information. Section 5 presents the implications for price behavior, while Section 6 provides concluding remarks.

\section{Data and summary statistics}

In order to analyze whether and how the broker network shapes trading outcomes and information diffusion in the market, one needs a detailed trade-level dataset that also reports information on the institutional investors and brokers involved in each trade. Abel Noser Solutions, formerly Ancerno Ltd. (we retain the name 'Ancerno' for simplicity), fittingly provides this information. Ancerno performs transaction cost analysis for institutional investors and makes these data available for academic research with a delay of three quarters under the agreement of non-disclosure of institutional identity.

We have access to anonymous identifiers for managers that initiate the trades and brokers that intermediate those trades from 1999 to $2014 .^{11}$ There are several advantages to this dataset. First, clients submit this information to obtain objective evaluations of their trading costs, and not to advertise their performance, suggesting that the data should not suffer from self-reporting bias. Second, Ancerno is free of survivorship biases, as it includes information about institutions that were reporting in the past but at some point terminated their relationship with Ancerno. Finally,

\footnotetext{
${ }^{10}$ Also related are the papers studying how cooperation and reputation among intermediaries affect liquidity costs in exchange markets. Battalio et al. (2007) documents an increase in liquidity costs in the trading days surrounding a stock's relocation to the floor of the exchange, while Pagano and Roell (1992) and Benveniste et al. (1992) demonstrate that reputation attenuate the repercussions of information asymmetries in trading and liquidity provision. More recently, Henderson et al. (2012) investigates the repeated interactions between placement agents (investment banks) and investors in the initial pricing of convertible bonds, whereas Cocco (2009) provides evidence from the interbank market that banks provide liquidity to one another at times of financial stress.

${ }^{11}$ Relative to the standard release of Ancerno that is available to other researchers, we managed to obtain numerical manager and broker identifiers also for the latest years (that is, after 2011), under the agreement that no attempt is made to identify the underlying institutional names.
} 
the dataset is devoid of backfill bias, as Ancerno reports only the trades that are dated from the start of the client relationship. Previous studies, such as Puckett and Yan (2011) and Anand, Irvine, Puckett, and Venkataraman $(2012$, 2013), have shown that the characteristics of stocks traded and held by Ancerno institutions and the return performance of the trades are comparable to those in $13 \mathrm{~F}$ mandatory filings.

Ancerno information is organized on different layers. At the trade-level, we know: the transaction date and time (at the minute precision); the execution price; the number of shares that are traded; the side (buy or sell); the stock CUSIP. We also know whether the trades are part of a unique ticket (i.e. an order with a broker). Our analysis is carried out at the ticket level. We therefore aggregate all trades belonging to the same order, by the same manager, executed through the same broker, on the same day.

Since the network of brokers generates our main source of variation, we provide several summary statistics to describe it. To limit noise in the definition of the broker network, we focus on the trades executed through the top 30 brokers by volume in the prior six months. ${ }^{12}$ These brokers intermediate more than $80 \%$ of the whole volume in the dataset.

Figure 1 depicts the network in this market. The larger blue circles represent the brokers in the market, the size of the circle being proportional to broker centrality. The smaller nodes capture the investors, with darker dots representing investors trading larger volumes. The brokers are connected to each other only through the investors. The average manager uses about 8 brokers to execute its trades. The average broker, instead, has more than 110 fund managers as clients. The investors in the periphery are the ones that are connected with only one or two brokers.

Our main measure of network centrality is the eigenvector centrality (Bonacich, 1972, Katz, 1953, Bonacich, 1987, and Bonacich and Lloyd, 2001). This variable takes into account all direct and indirect trading partners (i.e. fund managers and other brokers) and is computed by assigning scores to all brokers in the network. A broker-manager connection is weighted by the fraction of the total volume of the broker that is executed with the manager, where the volumes are computed over the prior six months. A broker's connection to managers that, in turn, are connected to many other brokers increases the broker's centrality score more than a similar number of connections to managers that only trade with that broker. In other words, what counts

\footnotetext{
${ }^{12}$ We have an agreement with our data provider that prevents us from disclosing the broker and trader identities.
} 
is not only the number of connections of a broker, but also who the broker is connected to. Figure 2 shows the kernel density estimation of the centrality measure. It shows that there is significant variation across brokers and that the distribution of the centrality measure is positively skewed, with the mass of brokers having low values and very few exhibiting very large values.

Central brokers can differ along other dimensions from the peripheral ones; for instance, they might charge different fees or have different price impact and execution speeds. Table 1 presents the summary statistics with Panel A and B focusing on the broker characteristics. We report the average of these characteristics for the top and bottom brokers in terms of their centrality. We find that top brokers intermediate higher volume, about 1 percent difference, have on average higher price impact, charge lower fees, display similar trade execution time, and intermediate higher volumes per trade.

We also ask whether the centrality measure is just identifying the largest brokers. To verify this, we rank brokers based on the total volume they intermediate in each month and find that there is only an $8 \%$ correlation between the network centrality measure and the volume ranking. Furthermore, in the next section we provide evidence that our results remain unaffected when we control for the volume intermediated by the broker. Figure 3 reports the coefficients of a regression of the centrality measure on its lags. It shows that our centrality measure is very persistent. Panel $\mathrm{C}$ of Table 1 complements the previous statistics by comparing brokers that intermediate volumes above and below the median. It shows that the differences in price impact and trading fees are even more significant: larger brokers have about $20 \%$ lower price impact and fees.

About three-thousand stocks are traded over our sample period by about 360 managers and 30 brokers (which is the number of brokers that we decided to focus on, see above). Panel D of Table 1 complements the previous evidence by providing key statistics for the stocks traded by different brokers. We find that central brokers tend to trade stocks with lower market capitalization, that are more illiquid, as captured by higher Amihud (2002) illiquidity measure and that exhibit lower analyst coverage and higher standard deviation of the analysts' estimates. These statistics suggest a greater role for information acquired by observing order flow. This information is more valuable when the stock is illiquid and when there is less public information 
(lower analyst coverage) or nosier information (higher dispersion of analysts' estimates). The key advantage of our empirical methodology is the possibility to control for these differences, for instance, by comparing similar trades for the same stock initiated by the same manager within the same timeframe.

To show that the centrality measure is a good proxy for the brokers' access to information, Panel E of Table 1 reports the characteristics of the managers trading with central and peripheral brokers. First of all, we measure the managers' horizon by computing their churn ratio and show that managers with shorter horizon are more likely to use central brokers to execute their trades. We also find that the managers that trade prevalently with central brokers trade a higher total and net volume. Furthermore, these funds also exhibit higher past trading performance. Finally, we identify the hedge funds in the database and distinguish between active and passive managers, and show that hedge funds and more active asset managers are more likely to trade with central brokers. All these results corroborate the view that centrality correlates with brokers' access to information as they interact prominently with traders that are more likely to be informed.

\section{Motivating Evidence: Network Centrality and Trading Profitability}

In this section, we provide evidence that central brokers are associated with significantly positive abnormal returns in both a portfolio setting and in regressions at the institutional trade level.

\subsection{Portfolio analysis}

We start our analysis by constructing monthly portfolios based on broker centrality. The goal is to test whether trades that are intermediated by brokers that are more central involve better performing stocks. One advantage of this methodology is the ability to report the economic significance of broker centrality for investors in a transparent way. This approach, however, is not immune to the concern that centrality correlates with some underlying stock characteristic that, in turn, correlates with expected returns. We address this concern in later analysis.

In detail, every three months, for each broker, we assign to each stock a score from one to ten based on the signed volume intermediated by the broker in that stock: a score of one will indicate 
heavily sold stocks (through the broker) and a score of ten will indicate heavily bought stocks. If a stock is not traded by any broker in the quarter, then we remove it from our set. Then we select the top and bottom six brokers (i.e. the top/bottom quintiles) based on our centrality measure, creating in this way two groups: the central brokers group and the peripheral brokers group. Within each brokers group, we compute the group-level stock score as the average of the brokerlevel stock scores across all the brokers in the group. Finally, for both brokers groups we compute a long/short, value-weighted portfolio by buying the stocks with a high group-level score and selling the stocks with a low group-level score. Our final high-minus-low centrality portfolio is built by buying the long/short portfolio of the central brokers and selling the long/short portfolio of the peripheral brokers. A stock remains in the portfolio for three months. ${ }^{13}$

We compute the average monthly returns on the high-minus-low centrality portfolio and obtain alphas from regressions on common risk factors. Panel A of Table 2 reports these results. We provide four specifications: raw returns and alphas from one-factor, three-factor, four-factor models (Carhart, 1997). Across specifications, we find a positive and significant performance for the high-minus-low centrality portfolio. Irrespective of the model, the alpha is around 40 basis points per month, which is about $4.8 \%$ on an annual basis. Panel B reports the performance of the two legs of the portfolio showing that significant excess returns are generated for almost two thirds by the long leg and for one third by the short leg. This suggests that the 40 bps excess returns are a combination of the trades executed through central brokers performing better than the market and the trades executed by peripheral ones underperforming it.

One potential explanation for the observed outperformance of central stocks is a pricepressure effect, similar to that identified by Coval and Stafford (2007). For example, central brokers may intermediate trades by investors that need to accommodate large inflows. In this case, the protracted price pressure could explain the abnormal returns. To investigate this possibility, we assess the persistence of the performance identified by the centrality measure. If the performance reverts towards zero after a few months, a price pressure effect is more likely. Hence, we extend the rebalancing frequency to one year and compute cumulative abnormal returns from a four-factor model. Figure 4 plots the returns over a twelve-month period for this portfolio (circled line). It shows that this high-minus-low centrality portfolio generates excess

\footnotetext{
${ }^{13}$ We have experimented with other holding periods (one month and six months) and found qualitatively similar
} results. 
returns from $0.40 \%$ up to $1.2 \%$ at longer horizons, significantly better than the close-to-zero returns generated by the portfolio that exploits information about the volume intermediated by all brokers, without conditioning on centrality (crossed line). Then, since the performance is fairly persistent over this horizon, it is unlikely that centrality captures price pressure effects à la Coval and Stafford (2007).

\subsection{Trade-Level Results}

One concern with the previous results is that the portfolio approach does not allow controlling for heterogeneity at the manager-broker level. For instance, better managers may systematically trade with central brokers. Then, the observed abnormal portfolio returns might just be the result of a matching between better managers and central brokers.

To address this concern, we exploit the depth of our data and compute a given manager's trading performance with a given broker. In detail, we estimate the following specification

$$
\text { Trading Performance }_{i j t}=\beta_{1} \text { Broker Centrality }_{j t}+X_{j t}+\gamma_{t}+\theta_{i}+\varepsilon_{i j t} \text {, }
$$

where the main dependent variable is the manager's trading performance with a given broker in a month, computed as the value-weighted return of the $T$-day-horizon trades executed by manager $i$ through broker $j$ during month $t$. In particular, the percentage performance of all trades by a manager with a given broker in a month is computed using closing prices over a $T$-day horizon, with sell trades' performance computed as the negative of a buy trade performance. ${ }^{14}$ The performance is computed using all the trades executed within each $T$-day horizon at the execution prices. Then, the performance is averaged across all $T$-day horizons within a month using the dollar volume of the trades as weights. Hence, the frequency is monthly.

The main coefficient of interest in equation (1) is $\beta_{1}$, which captures the relation between broker centrality and the manager's trading performance. The vector $X_{j t}$ includes controls such as the volume intermediated by the broker in the previous six months, as well as the average trade size. Given the granularity of our data, we can include time, manager, and manager-time fixed effects. The time unit is the month. Throughout the analysis, in computing standard errors we take the most conservative approach, double-clustering them at both the manager and the

\footnotetext{
${ }^{14}$ The $T$-day horizon starts at the open of each day and ends after $T$ days. The new $T$-day horizon starts after the closing of the previous one, without overlap. We value-weight the performance of all the trades in the same $T$-day horizon.
} 
time level. This procedure allows for arbitrary correlation across time and across managers. Table 3, Panel A, reports the results where we have divided the centrality measure by its standard deviation for ease of interpretation of the magnitudes (returns are expressed in basis points).

We use three different values for the trading horizon $T: 1,5$, and 10 days after the trade. For each horizon, the first specification only controls for time fixed effects, the second one also includes manager fixed effects, and the third one presents the results for the most conservative specification, with manager-time fixed effects. Overall, even restricting to trades made by the same manager in the same month, we find that more central brokers tend to intermediate more profitable trades. Thus, these results cannot be explained only by the fact that better managers trade systematically with more central brokers.

The results are also economically significant. For example, using the estimate in Column 6, we find that a one-standard-deviation increase in broker centrality increases performance by almost $15 \%$ relative to its mean (we are using the fact that the mean 5-day return is $8.7 \mathrm{bps}$ ). This result suggests that a significant source of alpha for fund managers might be the access to better connections. Note also that the results increase in magnitude when we consider the 5 and 10-day horizons (i.e. comparing Column 3 with Columns 6 and 9). This fact is helpful in ruling out the hypothesis that these excess returns could be driven by differences in price impact across brokers, as this competing hypothesis would imply decreasing coefficients over time. It also seems unlikely that these excess returns are attributable to a better execution by the more central brokers; since this hypothesis would not explain the effects being increasing over time either. ${ }^{15}$

\subsection{Potential Non-information-based Explanations}

In this subsection, we explore a set of potential explanations of our findings, which are unrelated to the informational content of the trades, while in Section 4 we present evidence supporting the

\footnotetext{
${ }^{15}$ It is interesting to check whether central brokers are able to capture these excess returns by charging higher fees to the investors. To check if this is indeed the case, we take advantage of the fact that Ancerno also reports data on the trading fees and commissions paid by the fund managers to the brokers. This allows us to compute a measure of trading performance net of fees. Table A.1 in the appendix reports our baseline specification with the net trading performance as dependent variable. A smaller or less significant coefficient would suggest that central brokers take advantage of their position in the network by generating rents predominantly for themselves. However, we find very similar results to the ones presented in Panel A. This is suggestive of the fact that the excess returns are not entirely captured by the brokers. Hence, central brokers possibly exploit their privileged position in the market by other means than higher fees, such as attracting new clients or more volume from the same clients.
} 
hypothesis that central brokers are able to generate higher excess returns thanks to their superior access to information.

\subsubsection{Central brokers intermediate higher volume}

One could conjecture that central brokers are also the largest brokers and, for this reason, they can intermediate transactions more efficiently. To directly test this hypothesis, the specification in equation (1) includes volume intermediated by the broker over the prior six months (in logs) and the average size of the trade as controls. The results suggest that the centrality measure is capturing other dimensions than the volume the brokers intermediate.

Furthermore, in the Appendix Table A.1 we show that our results are robust to including additional controls, such as the number of a broker's clients, the activeness of these clients, the number of hedge funds clients, the concentration of the clients' trades and the client's centrality measure (computed in a symmetric way relative to the broker's centrality).

\subsubsection{Central brokers trade different types of stocks}

Another potential explanation for the observed profitability of central broker trades may have to do with stock-level heterogeneity, including time-varying risk premia. Indeed, when we consider the trades made by the same manager at the same time through multiple brokers (Columns 3, 6 and 9 of Table 3), the results could still be explained by brokers trading different types of stocks.

To rule out this possibility, we exploit the depth of our data and obtain a finer aggregation of our regression sample at the stock-broker-manager-month-level. Specifically, we compute the trading performance of each manager $i$ trading stock $k$ with broker $j$ in month $t$, which allows us to include stock fixed effects. Formally, this is our new specification:

$$
\text { Trading Performance }_{i k j t}=\beta_{1} \text { Broker Centrality }_{j t}+X_{j t}+\theta_{i}+\mu_{k t}+\varepsilon_{i j t},
$$

which allows us to include stock-time fixed effects $\mu_{k t}$. Panel B of Table 3 reports the results for the 1-day, 5-day, and 10-day horizons. All specifications include the volume intermediated by the broker in the last six months and the average size of the trade. Columns 1, 4 and 7 control for time and stock fixed effects, Columns 2, 5 and 8 include stock-time fixed effects, while Columns 3, 6, and 9 include manager-stock-time fixed effects. The latter specification captures any timevarying heterogeneity at the stock and manager level by comparing the performance of the same manager trading the same stock in the same month with different brokers. 
This finer specification also allows us to rule out another mechanism that could explain our results: time-varying risk premiums for the stocks to the extent that it does not vary intra-month. Even with these more restrictive specifications the results are still economically and statistically significant: for instance, using the estimate in Column 6, a one-standard deviation increase in network centrality increases 5 -day performance by about $11 \%$ relative to its mean.

\subsubsection{Central Brokers provide better execution}

We have shown that variation across managers and stocks is not able to explain away the result that central brokers tend to generate higher excess returns. One potential explanation of this advantage is the fact that central brokers might be more skilled in trade execution. Institutional investors expect brokers to optimize their trading strategies. Hence, being central in the network of relationships with institutional investors might be correlated with their ability to provide better execution. For instance, central brokers might be more likely to trade at the best price during the day. Or, they could choose to trade when liquidity is the highest, so as to minimize price impact.

We formally test this hypothesis in Appendix Table A.2. The main difference with the previous specifications is the definition of the dependent variable. We compute the managers' trading performance using the opening price (Columns 1 and 2), the value weighted average daily price (Columns 3 and 4) and the closing price (Columns 5 and 6) rather than the actual price at which the trade is executed. This allows us to cleanse our findings from any variation that is a result of the intra-day timing of the trades and that can be attributable to the brokers' ability to execute the trades. In all specifications, we control for manager-stock-time fixed effects to focus on the variation coming from differences across brokers. We show that, even in this case, trades through central brokers perform significantly better, suggesting that better execution cannot explain away our results. ${ }^{16}$

\subsection{Who Benefits the Most?}

Having established that central brokers are able to generate higher excess returns, we investigate who benefits the most from trading with central brokers. Intuitively, if the explanation of the observed trading profitability hinges on the informational role of central brokers, we should observe the clients with the strongest relationship capturing higher returns than those trading

\footnotetext{
${ }^{16}$ In Appendix Table A.3 we also show that the brokers are not able to capture all the higher excess returns as the results hold when we look at net trading performance as the dependent variable.
} 
only occasionally with the brokers. We capture the strength of the broker-manager relationship in three different ways. First, we compute the volume intermediated by the broker for the manager in the previous six months and rank this measure in deciles. Second, we also measure the strength of the broker-manager relationship by taking into account the commissions paid by the manager to the broker in the previous six months and create a percentile ranking of this variable. Third, we identify the best clients as the ones that execute their trades with the broker more frequently and compute the number of days between two consecutive trades in the prior six months and multiply by minus one to obtain a measure of relationship strength. Notice that all of these measures are extremely persistent, suggesting that relationships between brokers and asset managers are valuable and not easily substitutable. Although these measures are all correlated, they capture different dimensions of the broker-manager relationships.

Table 4 reports the results for the following specification:

$$
\begin{aligned}
& \text { Trading Performance } \text { Skjt } \\
& \qquad \begin{array}{l}
=\beta_{1} \text { Broker Centrality }_{j t} \times \text { Relationship }_{i j t}+\beta_{2} \text { Broker Centrality }_{j t} \\
\quad+\beta_{3} \text { Relationship }_{i j t}+\theta_{i}+\mu_{k t}+\varphi_{j}+\varepsilon_{i j t}
\end{array}
\end{aligned}
$$

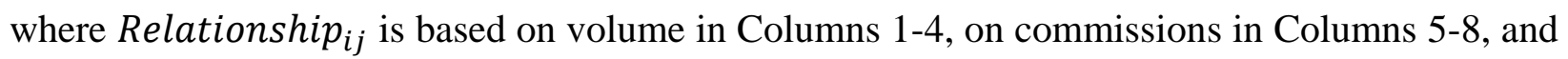
on the frequency of the interaction broker-manager in Columns 9-12. In all of these specifications we include the broker fixed effects $\varphi_{j}$. For each relationship measure, the first specification includes time and broker fixed effects. The second specification also includes stock-level controls such as the Amihud illiquidity measure, the stock market capitalization, the analyst coverage and the trade size. The third specification substitutes these controls with stock fixed effects, while the fourth specification is the most restrictive, as it includes stock-time fixed effects.

We find strong evidence that the managers with the strongest relationships with central brokers capture, on average, higher excess returns for each trade. This result indicates that the ultimate explanation of the higher profits accruing through central brokers needs to take the strength of the broker-client relationship into account. 


\section{Information Collection as the Source of Abnormal Returns}

Overall, the previous findings suggest that trades intermediated by more central brokers earn positive abnormal returns that cannot be explained away by the total volume brokers intermediate, by sorting of different managers with different brokers, by stock level characteristics, by time-varying risk of the stocks, or by brokers' execution ability. This evidence leaves the question open of how these returns are generated.

To understand how central brokers are able to generate higher excess returns, we turn to the theoretical literature for potential mechanisms. Recent theoretical studies such as Babus and Kondor (2016) show that central dealers can learn faster from the transactions they execute, increasing their trading gains, while Yang and Zhu (2016) show that investors can back-run informed traders by learning through order-flow.

Thus, both theories indicate as one potential source of returns for the central brokers the information that they can infer from the trades of their informed clients. In fact, we can imagine an informed trader submitting an order through a broker, who can infer the informational content of the trade and spreads it to other clients, especially the ones with closest ties. The incentive for the broker is to build a reputation as a valuable source of information and attract more business. ${ }^{17}$ One may think that the informed clients would not like their information to be spread to other investors. Section 4.6 proposes potential explanations for the managers' willingness to accept being exposed to information leakage and provides empirical evidence consistent with an equilibrium in which informed investors decide to share their private information.

\subsection{Informed Trades}

If central brokers disseminate information gathered by informed order flow, we should observe that in response to an informed trade, other investors are more likely to follow by executing similar trades, when the execution occurs through a central broker.

In order to test this hypothesis, we first identify informed trades as large trades executed by hedge fund managers. We define as large trade any net volume traded by a manager in a specific

\footnotetext{
${ }^{17}$ Recently, brokers have also generated profits by directly selling information about the order flow to institutional investors.
} 
stock, with a unique broker, over a time window of one week, which is larger than or equal to the $75^{\text {th }}$ percentile of the order imbalance distribution estimated from Ancerno data in the previous six months across all broker-manager pairs (order imbalance is scaled by the weekly trading volume in CRSP). ${ }^{18}$ We further condition on the executing manager to be a hedge fund. We identify hedge funds in Ancerno using the management company name.

One concern is that large trades might be motivated by liquidity needs. Then we first show that these trades tend to be informed trades. We do so by regressing in Table A.3 a dummy equal to one if the trade is profitable on an indicator variable identifying the large trades, controlling for stock characteristics. We find that indeed large trades are significantly more likely to be profitable. Furthermore, to rule out the possibility that these large trades are liquidity driven, we report in Panel A of Figure 5 the four-factor-adjusted cumulative returns for the stock before and after the big trade, at the daily frequency. We find that the stock price significantly increases with no evidence of reversal after twenty trading days. Panel B reports a similar graph for 52 weeks after the event and reporting separately the average returns of all trades and the average returns of profitable trades only. This evidence further suggests that the big trades that we identify are indeed informed trades.

We start our analysis of this information hypothesis by analyzing how the volume passing through central brokers changes around these large trades. We expect that, if other traders can take advantage of the information possessed by the informed trader (called henceforth originator) and disseminated by the broker, we should observe an increase in the volumes intermediated by central brokers after this large trade.

We formally test this hypothesis by considering the trading behavior of all the managers (called henceforth followers), other than the one generating the large trade, who trade the same stock with the same broker that executed the original large trade. We divide the sample into three sub-periods: the two trading weeks preceding the week in which the large trade was made (before); the period in which the large trade has started, but the originator is still trading in the same direction at a sustained pace (competition); and the period after the originator has stopped

\footnotetext{
${ }^{18}$ We find very similar results when we restrict attention to the trades in the top decile. To ensure that the large trade is not the consequence of prior trading activity in the stock, we also require that in the two weeks prior to the large trade the manager's imbalances in the stock and the stock return are not 'extreme', i.e. they are within two standard deviations of the mean of their distributions computed over the prior six months.
} 
trading, up to four weeks after the large trade week in which he initiated the trade sequence (after). Note that the competition period starts in the week of the large trade, but may potentially extend for several trading days after it has ended. ${ }^{19}$

Formally, we report in Panel A of Table 5 the results of the following specification:

$$
\text { Followers Trading }_{i k t}=\beta_{0} \text { Competition }_{j t}+\sum_{\tau=1}^{4} \beta_{\tau} \text { Wee }_{\tau}+\theta_{i t}+\mu_{k t}+\varepsilon_{i k t} \text {, }
$$

where the dependent variable is either a dummy that takes value one if the follower trades in the same direction as the originator and zero otherwise (Columns 1-2), or the log of the net dollar volume of the followers (Columns 3-4). We include as a control the logarithm of the dollar trade volume intermediated by each broker in the last six months and the logarithm of the large trade dollar volume. The specification allows us to control for heterogeneity among stocks and managers that might influence their trading behavior, because we include stock-time and manager-time fixed effects. The frequency of the observations is daily. The time unit for the fixed effects is the week.

We find that followers are significantly more likely to trade in the same direction of the informed trader during the competition period. We find a somewhat smaller effect also for the subsequent week. This means that the followers are generating price impact while the broker is still executing the originator's trade, which adversely affects the price at which the originator is able to trade. Conversely, we find that the followers unwind their trades in the following weeks, starting in the third week after the large trade. This trading behavior is consistent with an opportunistic strategy aiming to profit from the initial price appreciation due to the originator's trade.

\footnotetext{
${ }^{19}$ To define the exact starting moment of the large trade, we look at the cumulative net volume of the originator, starting from her first trade of the week and up to each of the following trades. We compare such net volume with the past distribution of all the net volumes on that stock in the previous six months, with any individual broker, traded by any manager in our sample during a number of days that is equal to the number of trading days that has passed since the originator's first trade (i.e. we compare one-day net volumes with one-day net volumes, two-days net volumes with two-days net volumes and so on). As soon as the net volume of the originator reaches the 75 th percentile of the benchmark distribution, we consider the large trade as started. Given our definition of a large trade, it must be that the large trade starts within the large trade week. An alternative signal we use to claim that the large trade has started is the observation of three trades (three buys or three sells) on the same stock, with the same broker, during the week: as soon as the third trade happens, we deem the large trade as started, independently of the cumulative net volume at that point. After the end of the large trade week, as soon as the originator trades a quantity below the $25 \%$ of her net traded volume on the day the large trade started, we consider the large trade as finished. This includes the cases in which the originator stays one or more days without trading the stock or when she trades in the opposite direction with respect to the large trade. What we define as competition period is the time between the moment in which the large trade starts and the last trade before the large trade finishes.
} 
Panel B tests the hypothesis that these effects are even more pronounced when the central brokers intermediate the large trades. We interact the time dummies with the measure of centrality of the broker that is executing the originator's order. We find that followers tend to trade the relevant stock even more when central brokers execute the originator's order; indeed, the interactions are large and statistically significant. This evidence further suggests the role of central brokers in intermediating large informed orders and disseminating this information to other asset managers.

An additional implication of the information channel is that if brokers have access to superior information, they should release it selectively, in a way that allows them to extract the highest rents. Panel $\mathrm{C}$ investigates this hypothesis by studying whether the followers' mimicking behavior that we document in Panel A depends on the strength of their relationship with the broker. The conjecture is that brokers have a stronger economic incentive to pass information to their best clients as a reward for their loyalty. The dependent variable is an indicator for whether the manager is executing the first trade in the same direction as the originator after the large trade during the Competition week or Week 1. Intuitively, the first followers receiving the information are able to trade early one and capture higher rents.

We use four different proxies for the strength of the manager-broker relationship. The first three proxies identify the top quarter of the distributions of the three following variables. First, we consider the trading volume that the manager originated for the broker in the past (Columns 1-3). More specifically, we divide the volume originated from the manager by the total volume intermediated by the broker, thus obtaining the percentage volume. Then, for each broker, we sort the managers in increasing order of volume and compute the measure as the cumulative percentage volume generated by each manager and all the other managers who traded less than she did with the broker. The second measure is computed in a very similar fashion, but the dollar volume is replaced by the dollar trading commissions generated by the manager (Columns 4-6). The third measure is obtained as the average number of days that passes from two consecutive trades of each manager with the same broker, multiplied by minus one (so that it is positively related with the trading frequency, (Columns 7-9). We estimate each proxy over the six months preceding the month in which the trading takes place. Another direction to look for selective disclosure is to identify managers that have common institutional affiliation with the broker. 
Hence, we collect information on the asset managers that belong to the same institution of the broker (Columns 10-12), which we identify using Capital IQ and Factiva.

The estimates suggest that managers with a stronger relationship with a given broker are significantly more likely to imitate the originator's trade in the Competition week and in Week 1, consistent with the conjecture and the results in Table 4. The effect is also economically important. For example, in Column 1, managers with the strongest relation are about $7 \%$ more likely to trade in the same direction as the originator in those weeks, relative to a baseline value for that probability of $24 \%$ (the constant in that regression).

\subsection{Similar investment styles?}

To provide evidence that these results are unlikely to be driven by the followers tracking the same investment styles as the informed trader, we check that these results hold even when we restrict attention to stocks that have not been previously traded by the followers, but that were heavily traded by the informed investor. That is, we focus on stocks that were not previously tracked by both groups of investors. More specifically, we keep in the sample only large trades performed on stocks that we deem as usual for the originator, and we consider only followers for which these stocks are deemed as unusual.

To assess whether a stock is usual or not for a manager, we look at the manager's volume in the stock in the previous six months, as a percentage of the total dollar volume traded by the manager. We then adjust this value to take into account the total number of stocks traded by the manager in the period. Finally, we consider as unusual for a manager all the stocks whose adjusted percentage volume lies below the tenth percentile of its distribution across all stocks/months in our sample. On the other hand, we consider as usual stocks for a manager all the stocks whose adjusted percentage volume lies above the fiftieth percentile of the same distribution. Table 6 presents the results. We show that even for this very restrictive subsample, followers tend to trade in the same direction of the originator, especially during the competition period and when the large order is executed by central brokers. The fact that we find similar evidence even in this sample is suggestive that the comovement among these investors' trades is unlikely to be due to the fact that the originator and the follower track similar investment styles. 
To rule out the possibility that the traders are all reacting to the same common information, Table 7 excludes days in which there are earning announcements for the stock as well as days in which analysts following the stock change their recommendations. We confirm our results even in this subsample, showing that our results are not driven by these news events.

\subsection{Placebo Tests}

To corroborate the view that the large informed order really constitutes the event that triggers the imitation by the followers, we shift the timeline of our event window to one month before the large trade, and report the baseline specification in Table 8 (Panels A and B). We do not find any significant trading of the followers in that stock. By showing the lack of correlated trades in absence of the large trade, this "placebo" test corroborates the interpretation of the results that the followers have been tipped off by the broker executing the large informed trade.

The conjecture that the broker intermediating the large trade leaks information to its other clients suggests an additional placebo test. We run similar specifications to the ones in Panels A and B of Table 5 and focus on the trades that are executed through brokers that are different from the broker that intermediated the large trade. In this case, we expect the trading to be less correlated with the large trade. Table 8 (Panels C and D) confirms this conjecture; we find that in the competition period, the probability of the other trades to be in the same direction as the large trade, as well as the imbalances, is an order of magnitudes smaller than when we look at the volume intermediated through the original broker. Moreover, in the periods following the big trade, we do not observe any significant correlation. This test is also helpful in ruling out an alternative hypothesis that the traders are reacting to some common public information. In fact, if that were the case, there should not be any particular reason why the trades are all executed by the broker who executes the originator's large trade. Instead, our results support the view that the broker who becomes informed about large movements in the price, spreads this information to his clients in order to maximize the volume he intermediates.

\subsection{What if the Originator is Affiliated?}

An implication of the information leakage channel is that brokers intermediating the large trades would reduce the occurrence of back running if the large trader and the broker are part of the 
same institution. To test this hypothesis, we employ Capital IQ and Factiva to identify the funds that have the same institutional affiliation as the brokers.

Table 9 reports the baseline regressions for the probability of imitating the originator (Panel A) and the dollar imbalances (Panel B), differentiating between type of originator. Columns (1)(4) of both panels restrict attention to originators that are affiliated to the broker who execute their trades. Columns (5)-(8) show the results for all the other clients. We also differentiate between central brokers (Columns 1-2 and 5-6) and peripheral ones (Columns 3-4 and 7-8). For both dependent variables, we find that, when the informed trader is affiliated with a central broker, there is no imitation during the competition period or afterwards. Notice that not only is the coefficient not statistically significant, but also its magnitude is just a fraction of the baseline coefficients. Interestingly, when we look at the large trades originated by other non-affiliated clients, or at peripheral brokers, we find that there is a significant imitation.

These results suggest that central brokers preempt the competition by other traders when the informed trader belongs to the same institution. Thus, if this information leakage was only the result of normal market making activities, such as contacting potential counterparties to fill the informed order, we should not observe such heterogeneous effects depending on the identity of the originator.

\subsection{Information about Activists' Trading}

Another important setting in which we can test our information hypothesis is when activists build up their holdings in a target firm. Specifically, to provide further evidence that information is indeed leaked by brokers to other traders, we analyze investors' behavior around 13D filings. Activists' trading provides another natural setting to test our information hypothesis for at least

three reasons. First, activists' target companies tend to experience significant price changes once the activists' strategies are released. Second, there is a clear date after which the information about the activists' taking an interest in a company becomes public. Third, there are ten days in which the only market participant knowing about the activist's trades is the broker, as activists have ten days to file a 13D form with the SEC upon reaching a 5\% stake in the company they are targeting. 
We collect information from the 13D filings between 1999 and 2014. These filings contain the name of the activists and the stock they bought. Using the ADV Forms from the SEC, which all registered advisor file, along with the commercial hedge fund databases TASS and HFR, we are able to extract information about the broker with which the activists trade. Then we can match our Ancerno data on the brokers with information about these activists' trades. If brokers were releasing information about their order flow, we should expect other traders to buy the stock of the target company before the $13 \mathrm{D}$ is filed, which is when the information is released to all market participants.

Table 10 presents the results. The dependent variable is either a dummy identifying "Buy" trades (Panel A) or the log of dollar net volumes from the manager, multiplied by 1 in case of a net buy volume, or by -1 in case of a net sale volume (Panel B). We consider an event window of 60 trading days before and after the filing. We investigate the investors' trading behavior by differentiating among three time periods: the day on which the 13D is filed (Filing Day), the 10 trading days before the filing (Just Before) and the period that goes from 60 to 10 trading days before the filing (Before). The reference period is the time after the filing, once the information is publicly released.

We interact the time dummies with a dummy (Strong Relation) that identifies, among all the managers who are trading the stock, the ones who have a stronger relationship with the activist's prime broker. The idea is that the broker will have a higher incentive to share their order flow information with their best clients. The four different proxies are defined as in Panel C of Table 5.

Consistently across dependent variables and specifications, we find a positive value for the coefficient of the interaction between the Just Before dummy and the relationship dummy. This indicates that the broker's best client bought more the target stock than the other managers right before the 13D, compared to what they did after the 13D filing, while we find no differential trading in the other periods. This strongly suggests that these investors were made aware of the interest in that particular stock by the broker who executed the activist's trades.

To be sure of capturing any time-invariant characteristic at the manager and at the stock level, we control for manager and stock fixed effects in addition to time fixed effects (odd columns). Furthermore, in our most conservative specification we include stock by time fixed effect (even 
columns), which captures any other time-varying characteristic of the stock, such as its liquidity or the release of other news, which might induce investors to change their positions on that particular stock. Our results hold even in the most conservative specifications.

Panels C-F also relate these results to our centrality measure by running a similar analysis separately for central and peripheral brokers. We find that the results are significant only in the subsample of central brokers, further confirming that the central brokers are more prone to share order flow information.

\subsection{Why do informed investors stick with the leaking broker?}

Having established that brokers play a pivotal role in disseminating order flow information, one might wonder why an informed asset manager is willing to trade with brokers that tend to leak to other market participants. We put forward several non-mutually-exclusive potential explanations.

First, fund managers may decide to neglect this behavior of the brokers simply because their performance is not significantly affected by it. Specifically, long-horizon investors are less concerned with the short-term impact of their trades than a high-frequency trader. Thus, one would expect the former to be less wary in the allocation of the trades across brokers and more willing to accept the leakage in exchange for the brokers' execution services.

Second, institutional investors might not have a valid alternative when deciding where to route their trades. Goldstein, Irvine, Kandel, and Wiener (2009) show that on average fund managers tend to concentrate about $40 \%$ of their trades with their top broker. This allows institutional investors to be compensated by receiving better financing terms or through a better deal allocation during equity offerings. This suggests that it might be very costly to suddenly channel informed trades through brokers for whom the manager is not a top client, this could entail, e.g., worse execution, higher commissions, and more significant leakage to other market participants.

Another potential explanation relies on the repeated nature of the trading relationship between the broker and a trader. Specifically, institutional investors will repeatedly interact with the same brokers over time, which might allow the broker to compensate the informed traders in different ways. This makes it plausible that a restricted number of institutional investors find it profitable 
to trade with central brokers when they are informed, if they believe that they will be on the receiving end of the order flow information when other informed market participants trade with the broker. That is, the smart money can actually form a club. The repeated nature of the interactions would allow for monitoring and punishment devices. For instance, the fact that a broker can infer the informational content of a manager's order flow gives the broker the ability to monitor a manager's potential deviation from this collusive behavior, making a deviation less likely.

We can formally test the club-hypothesis by analyzing whether being an informed trader in the past (i.e. information supplier) predicts being a follower in the future (i.e. an information receiver). Table 11 shows that this is indeed the case, with investors that have acted as originators in the past being more likely to be among the followers in the next quarter and even more so to be the followers that imitate the informed trade during the competition period.

This result suggests that some asset managers are willing to give up some of their advantage because by doing so they will be able to extract rents in the future when other market participants are informed.

\section{Implications for Price Behavior}

We have provided evidence establishing that central brokers are able to generate excess returns thanks to the information they gather by observing informed trades. This raises the question of whether central brokers' behavior improves price discovery. On the one hand, by disseminating private information faster, asset prices might reflect this information more effectively. On the other hand, brokers might lead to overshooting as they share their information with multiple managers who can then trade on this and move prices away from fundamentals.

We start analyzing this question in Figure 6 by showing the average cumulative abnormal return of the stocks interested by a large trade before, during, and after the week in which the large trade is identified. We separate between large trades intermediated by central broker (line with triangles) and peripheral brokers (line with circles). The shaded areas identify the standard errors. The graph shows that, when a big trade passes through a central broker, the price achieves its new level more quickly. One can contrast this with the price behavior with peripheral brokers 
suggesting that, after the first week, the stock price has only achieved two thirds of its long-term level. In brief, central brokers seem to be associated with a faster movement of prices to their equilibrium level. Therefore, this evidence corroborates the hypothesis that information dissemination by central brokers might enhance price discovery.

We further test this possibility by studying the adjustment of prices after the large informed trade. We follow DellaVigna and Pollet (2009) and construct the price response ratio after a large trade, defined as the ratio between the cumulative four-factor-adjusted returns on day 5 and day 24. The idea is that, as the price incorporates information faster, we should observe a higher response ratio, i.e. the cumulative returns after few days are not very different from the returns achieved a few weeks after the event.

Figure 7 plots the coefficients of a regression relating the response ratio to the deciles of the brokers' centrality. We find that the response ratio increases with the broker centrality, suggesting that prices adjust more quickly after large trades when these are executed by central brokers. In unreported results, we find this relation to be statistically significant. Moreover, the figures shows that the response ratios are larger than $100 \%$ for more central brokers, confirming the evidence of slight price overshooting that appeared in Figure 6.

Overall, these results suggest that central brokers speed up the price discovery process, but may induce some overshooting in the short run.

\section{Conclusion}

This paper presents three main findings. First, it shows that trades placed through more central brokers generate significantly higher abnormal returns. Second, we present evidence that is consistent with the conjecture that these excess returns result from central brokers disseminating the information they capture by observing informed investors' trading. Finally, we show that information sharing may enhance market efficiency by incorporating information into prices more quickly.

These results have several implications. First, our findings highlight that an important source

of returns for fund managers in the stock market is not information production per se. Rather, 
some managers appear to free-ride on the information provided by stock brokers, which in turn is acquired thanks to their privileged position in the trading network. Second, since Kyle (1985), a slow execution is considered optimal in order to minimize price impact. However, our results show that there exists an important trade-off between price impact and information leakage due to the intermediation of the brokers who might act on their own best interest and disseminate information about order flow. Finally, our results contribute to the debate on the value of delegated portfolio management and the nature of the services that asset managers provide to their clients. Since building a relationship with brokers requires a scale and a reputation that is not accessible to retail investors, the fact that a connection to the right brokers generates investment performance provides a "justification” for delegated portfolio management.

Overall, the evidence in the paper suggests that the broker network has important implications for how information is impounded into prices and for the generation of trading profits. Future research should focus on the role of brokers in affecting information diffusion during periods of market turmoil to test whether their behavior might also lead to exacerbation of distressed situations such as fire sales. 


\section{References}

Acemoglu, Daron, Munther A. Dahleh, Ilan Lobel, and Asuman Ozdaglar, 2011. "Bayesian Learning in Social Networks.” The Review of Economic Studies, 78: 1201-1236.

Afonso, G., Kovner, A. and Schoar, A., 2013. "Trading partners in the interbank lending market." FRB of New York Staff Report, (620).

Amihud, Yakov, 2002. "Illiquidity and stock returns: cross-section and time-series effects." Journal of financial markets, 5(1), 31-56.

Anand, Amber, Paul Irvine, Andy Puckett, and Kumar Venkataraman, 2012. "Performance of institutional trading desks: An analysis of persistence in trading costs." Review of Financial Studies 25, 557-598.

Anand, Amber, Paul Irvine, Andy Puckett, and Kumar Venkataraman, 2013. "Institutional trading and stock resiliency: Evidence from 2007-2009 financial crisis." Journal of Financial Economics, 108, 773-793.

Andrei, Daniel, and Julien Cujean, 2017, "Information percolation, momentum and reversal," Journal of Financial Economics 123(3), 617-645.

Alatas, V., Banerjee, A., Chandrasekhar, A.G., Hanna, R. and Olken, B.A., 2016. "Network Structure and the Aggregation of Information: Theory and Evidence from Indonesia." American Economic Review, 106(7), 1663-1704.

Babus, A. and Kondor, P., 2016. "Trading and information diffusion in over-the-counter markets.” Working Paper, London School of Economics.

Bandiera, Oriana, Iwan Barankay, and Imran Rasul. 2009. "Social Connections and Incentives in the Workplace: Evidence from Personnel Data.” Econometrica, 77 (4), 1047-94.

Bandiera, Oriana, Robin Burgess, Selim Gulesci, Imran Rasul, and Munshi Sulaiman, 2012. “Can Entrepreneurship Programs Transform the Lives of the Poor?” Unpublished.

Bandiera, Oriana, and Imran Rasul, 2006. "Social Networks and Technology Adoption in Northern Mozambique.” Economic Journal, 116 (514), 869-902.

Banerjee, Abhijit, Emily Breza, Arun G. Chandrasekhar, Esther Duflo, and Matthew O. Jackson, 2012. “Come Play with Me: Experimental Evidence of Information Diffusion about Rival 
Goods." Unpublished.

Banerjee, Abhijit, Arun G. Chandrasekhar, Esther Duflo, and Matthew O. Jackson, 2013. "The Diffusion of Microfinance." Science, 341 (6144).

Banerjee, Abhijit, Arun G. Chandrasekhar, Esther Duflo, and Matthew O. Jackson, 2014. "Gossip: Identifying Central Individuals in a Social Network." Unpublished.

Barberis, Nicholas, and Andrei Shleifer, 2003. "Style investing." Journal of Financial Economics, 68(2), 161-199.

Berk, J.B. and Green, R.C., 2004. "Mutual Fund Flows and Performance in Rational Markets." Journal of Political Economy, 112(6), 1269-1295.

Brogaard, Jonathan, Terrence Hendershott, and Ryan Riordan, 2014. "High-frequency trading and price discovery." Review of Financial Studies, 27(8), 2267-2306.

Bonacich, P., 1972. "Factoring and weighting approaches to status scores and clique identification." Journal of Mathematical Sociology, 2: 113-120.

Bonacich, P., 1987. "Power and centrality: A family of measures." American Journal of Sociology, 92: 1170-1182.

Bonacich, P., and P. Lloyd, 2001. "Eigenvector-like measures of centrality for asymmetric relations." Social Networks, 23: 191-201.

Boyarchenko, N., Lucca, D.O. and Veldkamp, L., 2016, "Taking Orders and Taking Notes: Dealer Information Sharing in Treasury Markets" National Bureau of Economic Research No 22461.

Carhart, Mark M., 1997. "On persistence in mutual fund performance." Journal of Finance $52(1), 57-82$.

Colla, Paolo and Antonio Mele, 2010. "Information linkages and correlated trading." Review of Financial Studies, 23(1), 203-246.

Collin-Dufresne, Pierre and Vyacheslav Fos, 2015, "Do prices reveal the presence of informed trading?" Journal of Finance, 70(4), 1555-1582.

Conley, Timothy G., and Christopher R. Udry, 2010. "Learning about a New Technology: 
Pineapple in Ghana." American Economic Review 100(1), 35-69.

Coval, J. and Stafford, E., 2007. "Asset fire sales (and purchases) in equity markets." Journal of Financial Economics, 86(2), pp.479-512.

Chung, J.W. and Kang, B.U., 2016. "Prime Broker-Level Comovement in Hedge Fund Returns: Information or Contagion?" Available at SSRN 2396522.

DellaVigna, Stefano, and Joshua M. Pollet, 2009. "Investor inattention and Friday earnings announcements." Journal of Finance 64(2), 709-749.

DeMarzo, Peter, Dimitri Vayanos, and Jeffrey Zwiebel, 2003. "Persuasion Bias, Social Influence, and Unidimensional Opinions.” Quarterly Journal of Economics 118, 909-968.

Di Maggio M., Kermani A., Song Z., 2017. "The Value of Trading Relationships in Turbulent Times." Journal of Financial Economics 124(2), 266-284.

Duffie, D., Giroux, G. and Manso, G., 2010. "Information percolation." American Economic Journal: Microeconomics 2(1), 100-111.

Duffie, Darrell, Semyon Malamud, and Gustavo Manso, 2009. "Information Percolation With Equilibrium Search Dynamics.” Econometrica 77(5): 1513-1574.

Duffie, D., Malamud, S. and Manso, G., 2014. "Information percolation in segmented markets." Journal of Economic Theory 153, 1-32.

Duflo, Esther, Michael Kremer, and Jonathan Robinson, 2004. "Understanding Technology Adoption: Fertilizer in Western Kenya, Preliminary Results from Field Experiments." Unpublished.

Farboodi, Maryam, and Laura Veldkamp, 2017, Long Run Growth of Financial Technology. Working Paper.

Fracassi, C. and Tate, G., 2012. "External networking and internal firm governance." Journal of Finance, 67(1), 153-194.

Gabrieli, Silvia, and Co-Pierre Georg, 2014. "A network view on interbank market freezes." Banque de France Working Paper.

Gennaioli, Nicola, Andrei Shleifer, and Robert Vishny. "Money doctors." The Journal of 
Finance 70.1 (2015): 91-114.

Goldstein, Michael A., Paul Irvine, Eugene Kandel, and Zvi Wiener, 2009, Brokerage commissions and institutional trading patterns, Review of Financial Studies 22(12), 5175-212.

Golub, Ben, and Matthew O. Jackson, 2010. "Naive Learning in Social Networks: Convergence, Influence, and the Wisdom of Crowds." American Economic Journal: Microeconomics, 2: 112149.

Hendershott, T., Li, D., Livdan, D. and Schürhoff, N., 2016. "Relationship trading in OTC markets." Swiss Finance Institute, Working Paper.

Hendershott, Terrence, Dmitry Livdan, and Norman Schürhoff, 2015. "Are institutions informed about news?.” Journal of Financial Economics, 117(2), 249-287.

Hollifield, B., Neklyudov, A. and Spatt, C.S., 2014. "Bid-Ask Spreads, Trading Networks and the Pricing of Securitizations: 144a vs. Registered Securitizations.” Working Paper.

Hortacsu, A. and J. Kastl (2012): "Valuing Dealers' Informational Advantage: A Study of Canadian Treasury Auctions," Econometrica, 80, 2511-2542.

Jackson, Matthew O., and Brian W. Rogers, 2007. "Meeting Strangers and Friends of Friends: How Random Are Social Networks?” American Economic Review, 97(3): 890-915.

Katz, L., 1953. “A new status index derived from sociometric analysis.” Psychometrika, 18: 3943.

Kovbasyuk, Sergei, and Marco Pagano, 2015. "Advertising Arbitrage." Available at SSRN 2431270 .

Lerner, J. and Malmendier, U., 2013. "With a little help from my (random) friends: Success and failure in post-business school entrepreneurship." Review of Financial Studies, 26(10), 24112452.

Li, D. and Schürhoff, N., 2014. “Dealer networks.” Working Paper, Swiss Finance Institute.

Li, Frank Weikai, Abhiroop Mukherjee, and Rik Sen, 2016, Inside Brokers. Working Paper, HKUST.

Ljungqvist, A. and Qian, W., 2016. "How Constraining Are Limits to Arbitrage?." Review of 
Financial Studies, forthcoming.

Munshi, Kaivan, 2003. "Networks in the Modern Economy: Mexican Migrants in the US Labor Market." Quarterly Journal of Economics, 118 (2): 549-99.

Munshi, Kaivan, 2004. "Social Learning in a Heterogeneous Population: Technology Diffusion in the Indian Green Revolution.” Journal of Development Economics, 73 (1), 185-213.

Nguyen, B.D., 2012. "Does the Rolodex matter? Corporate elite's small world and the effectiveness of boards of directors." Management Science, 58(2), 236-252.

Ozsoylev, H.N., Walden, J., Yavuz, M.D. and Bildik, R., 2014. "Investor networks in the stock market." Review of Financial Studies, 27(5), 1323-1366.

Puckett, Andy, and Xuemin (Sterling) Yan, 2011. "The interim trading skills of institutional investors." Journal of Finance, 66, 601-633.

Shue, K., 2013. "Executive networks and firm policies: Evidence from the random assignment of MBA peers." Review of Financial Studies, 26(6), 1401-1442.

Walden, Johan, 2014. "Trading, profits, and volatility in a dynamic information network model." Available at SSRN 2561055.

Yang, Liyan, and Haoxiang Zhu, 2016, "Back-running: Seeking and hiding fundamental information in order flows." Rotman School of Management Working Paper 2583915. 
Table 1. Summary Statistics

This table reports the summary statistics for different subsamples. Panel A reports the main summary statistics for the brokers. Panel B differentiates between central and peripheral brokers and reports the difference. Panel $\mathrm{C}$ also reports the differences between brokers that intermediate volume above and below the median. Panel D reports key stats for the stocks traded through central and peripheral brokers. Panel E reports the average eigenvector centrality for different classes of managers. For each manager, we compute a volume-weighted average of the eigenvector centrality of the brokers chosen by the manager to execute their trades. Then, in each month, we rank the managers based on their characteristics and compute the average centrality of the brokers used by managers who lie above or below the crosssectional median of the characteristic of interest. The characteristics we take into consideration are proxies of the managers' turnover (churn ratio and adjusted churn ratio), size (net volume and total volume), information (past performance and hedge fund) and degree of activeness (active and adj. active).

\section{Panel A: All Brokers}

ALL BROKERS

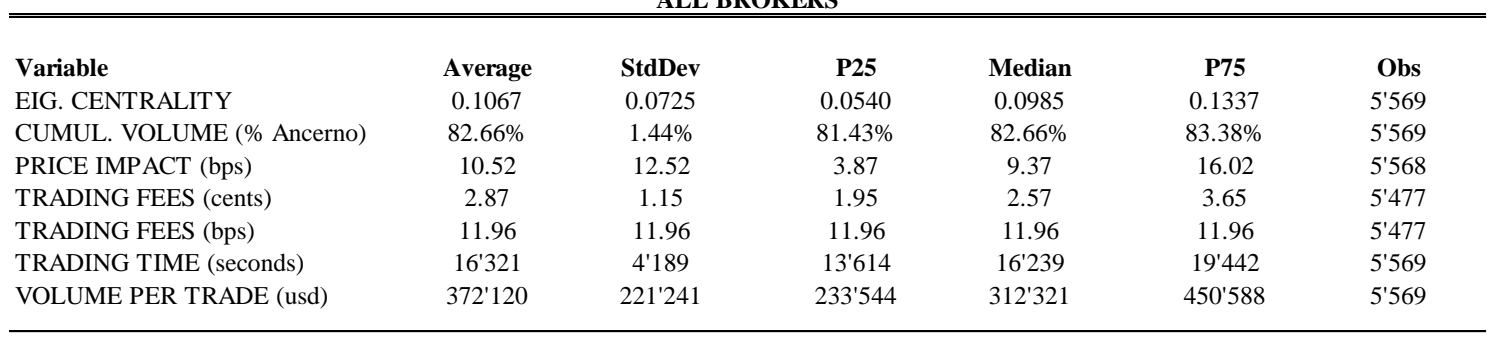

Panel B: Central vs. Peripheral Brokers

CENTRALITY Below Median CENTRALITY Above Median CENTRAL vs PERIPHERAL

\begin{tabular}{|c|c|c|c|c|c|}
\hline Variable & Average & StdDev & Average & StdDev & \\
\hline EIG. CENTRALITY & 0.0570 & 0.0296 & 0.1565 & 0.0685 & $0.0995 * * *$ \\
\hline VOLUME (\% Ancerno) & $2.10 \%$ & $2.00 \%$ & $3.43 \%$ & $2.41 \%$ & $1.33 \% * * *$ \\
\hline PRICE IMPACT (bps) & 10.01 & 11.54 & 11.04 & 13.41 & $1.03 * * *$ \\
\hline TRADING FEES (cents) & 2.98 & 1.09 & 2.75 & 1.19 & $-0.24 * * *$ \\
\hline TRADING FEES (bps) & 12.42 & 4.80 & 11.48 & 5.33 & $-0.94 * * *$ \\
\hline TRADING TIME (seconds) & 16,349 & 4,358 & 16,293 & 4,014 & -56 \\
\hline VOLUME PER TRADE (usd) & 351,159 & 181,904 & 393,118 & 252,925 & $41,959 * * *$ \\
\hline
\end{tabular}

Panel C: High vs. Low Volume

\begin{tabular}{|c|c|c|c|c|c|}
\hline & \multicolumn{2}{|c|}{ VOLUME Below Median } & \multicolumn{2}{|c|}{ VOLUME Above Median } & \multirow[t]{2}{*}{ HIGH vs. LOW VOLUME } \\
\hline Variable & Average & StdDev & Average & StdDev & \\
\hline EIG. CENTRALITY & 0.1018 & 0.0811 & 0.1115 & 0.0624 & $0.0097 * * *$ \\
\hline VOLUME (\% Ancerno) & $0.96 \%$ & $0.32 \%$ & $4.55 \%$ & $2.03 \%$ & $3.59 \% * * *$ \\
\hline PRICE IMPACT (bps) & 11.61 & 14.47 & 9.44 & 10.11 & $-2.17 * * *$ \\
\hline TRADING FEES (cents) & 3.16 & 1.20 & 2.58 & 1.01 & $-0.57 * * *$ \\
\hline TRADING FEES (bps) & 13.12 & 5.27 & 10.81 & 4.62 & $-2.31 * * *$ \\
\hline TRADING TIME (seconds) & $16^{\prime} 024$ & 4'728 & $16^{\prime} 617$ & 3'549 & $592 * * *$ \\
\hline VOLUME PER TRADE (usd) & $415^{\prime} 795$ & $257^{\prime} 786$ & $328^{\prime} 617$ & $166 ' 536$ & $-87^{\prime} 178 * * *$ \\
\hline
\end{tabular}


Panel D. Stocks

\begin{tabular}{|c|c|c|c|c|c|c|}
\hline \multirow[b]{2}{*}{ Variable } & \multicolumn{2}{|c|}{$\begin{array}{l}\text { Stocks traded by Central } \\
\text { Borkers }\end{array}$} & \multicolumn{2}{|c|}{$\begin{array}{c}\text { Stocks traded by Peripheral } \\
\text { Borkers }\end{array}$} & \multicolumn{2}{|c|}{ CENTRAL vs PERIPHERAL } \\
\hline & Average & StdDev & Average & StdDev & Obs & Difference \\
\hline MARKET CAP. & 16.78 & 34.59 & 16.02 & 33.49 & $22,500,187$ & $-0.76 * * *$ \\
\hline AMIHUD PAST $12 \mathrm{M}$ & 0.00013 & 0.00622 & 0.00014 & 0.00659 & $22,498,168$ & $9.196 \mathrm{E}-06 * * *$ \\
\hline AMIHUD & 0.00008 & 0.01128 & 0.00010 & 0.01277 & $22,690,587$ & 1.745E-05*** \\
\hline ANALYST COVERAGE & 13.36 & 8.08 & 13.30 & 8.15 & $20,486,038$ & $-0.06 * * *$ \\
\hline STD.DEV. Of ANALYST EST. & $7.85 \%$ & $16.58 \%$ & $8.28 \%$ & $17.24 \%$ & $20,034,710$ & $0.43 \% * * *$ \\
\hline
\end{tabular}

Panel E. Broker Choice by different classes of Managers

Average Eigenvector Centrality of the Brokers chosen by different classes of Managers

\begin{tabular}{lccccc}
\hline \hline Manager Classification & LOW & HIGH & Difference & t-stat & p-value \\
CHURN RATIO & 0.0870 & 0.0934 & 0.0065 & $21.98^{* * *}$ & 0.000 \\
ADJ. CHURN RATIO & 0.0867 & 0.0937 & 0.0069 & $23.54 * * *$ & 0.000 \\
NET VOLUME & 0.0862 & 0.0943 & 0.0081 & $28.06 * * *$ & 0.000 \\
TOTAL VOLUME & 0.0857 & 0.0947 & 0.0090 & $31.38 * * *$ & 0.000 \\
PAST PERFORMANCE & 0.0897 & 0.0907 & 0.0010 & $3.48 * * *$ & 0.000 \\
HEDGE FUND (NO/YES) & 0.0901 & 0.0908 & 0.0008 & $2.27 * *$ & 0.023 \\
ACTIVE & 0.0896 & 0.0909 & 0.0014 & $4.68 * * *$ & 0.000 \\
ADJ. ACTIVE & 0.0896 & 0.0909 & 0.0013 & $4.60 * * *$ & 0.000 \\
& & & & & \\
\hline
\end{tabular}


Table 2. Portfolio Results

This table reports the coefficient estimates of the alpha of our high-minus-low centrality portfolio. We split the brokers in our sample into two categories: central and peripheral. Stocks are ranked every three months based on the average percentage imbalances intermediated by the brokers within each category. For each broker category we form a value-weighted, long/short portfolio. Both portfolios are long strongly bought stocks and short strongly sold stocks. Our final high-minus-low centrality portfolio is built by buying the central-brokers portfolio and selling the peripheral-brokers portfolio. Panel A reports the monthly returns of the high-minus-low centrality portfolio regressed on common risk factors. Panel B shows the monthly returns of the long and the short leg of the high-minus-low centrality portfolio (i.e. the central-brokers portfolio and selling the peripheral-brokers portfolio) regressed on common risk factors. T-statistics are reported in parentheses. Asterisks denote significance levels $(* * *=1 \%, * *=5 \%, *=10 \%)$.

\section{Panel A: High-minus-low centrality portfolio}

\begin{tabular}{lcccc}
\multicolumn{1}{l}{ Dependent Variable: Monthly returns of the high-minus-low centrality portfolio } \\
\hline \hline
\end{tabular}

Panel B: Long and short leg of the high-minus-low centrality portfolio separately

Dependent Variable: Monthly returns of the LONG and the SHORT LEG of the high-minus-low centrality portfolio

\begin{tabular}{|c|c|c|c|c|c|c|c|c|}
\hline \multirow[b]{2}{*}{ Alpha } & \multicolumn{4}{|c|}{ LONG leg } & \multicolumn{4}{|c|}{ SHORT leg } \\
\hline & $\begin{array}{c}29.36 * * \\
(2.602)\end{array}$ & $\begin{array}{c}29.16 * * \\
(2.567)\end{array}$ & $\begin{array}{l}22.97 * * \\
(2.050)\end{array}$ & $\begin{array}{l}23.89 * * \\
(2.124)\end{array}$ & $\begin{array}{l}-17.57 * \\
(-1.814)\end{array}$ & $\begin{array}{l}-18.67 * \\
(-1.923)\end{array}$ & $\begin{array}{l}-17.90^{*} \\
(-1.812)\end{array}$ & $\begin{array}{l}-18.88 * \\
(-1.907)\end{array}$ \\
\hline Excess Market Return & & $\begin{array}{c}0.00464 \\
(0.188)\end{array}$ & $\begin{array}{l}-0.0116 \\
(-0.465)\end{array}$ & $\begin{array}{l}-0.0219 \\
(-0.807)\end{array}$ & & $\begin{array}{l}0.0260 \\
(1.227)\end{array}$ & $\begin{array}{l}0.0304 \\
(1.382)\end{array}$ & $\begin{array}{c}0.0414 * \\
(1.734)\end{array}$ \\
\hline SMB & & & $\begin{array}{c}0.112 * * * \\
(3.219)\end{array}$ & $\begin{array}{c}0.120 * * * \\
(3.350)\end{array}$ & & & $\begin{array}{l}-0.0229 \\
(-0.744)\end{array}$ & $\begin{array}{l}-0.0307 \\
(-0.976)\end{array}$ \\
\hline HML & & & $\begin{array}{c}0.0588 * \\
(1.773)\end{array}$ & $\begin{array}{l}0.0523 \\
(1.548)\end{array}$ & & & $\begin{array}{c}0.00444 \\
(0.152)\end{array}$ & $\begin{array}{r}0.0113 \\
(0.380)\end{array}$ \\
\hline UMD & & & & $\begin{array}{l}-0.0206 \\
(-0.966)\end{array}$ & & & & $\begin{array}{l}0.0220 \\
(1.175)\end{array}$ \\
\hline Observations & 186 & 186 & 186 & 186 & 186 & 186 & 186 & 186 \\
\hline R-squared & 0.000 & 0.000 & 0.063 & 0.068 & 0.000 & 0.008 & 0.011 & 0.019 \\
\hline
\end{tabular}




\section{Table 3. Returns and Brokers' Volume}

This table regress the value-weighted trading performance at different time horizons (in basis points) on our centrality measures. In Panel A our database is collapsed at the broker/manager/ month level; we include as a control the natural logarithm of the dollar trade volume intermediated by each broker in the last six months and the average dollar volume traded by the manager with the broker in the month in which performance is assessed. In Panel B, our database is collapsed at the broker/manager/stock/month level, thus we are able to add stock, stock/time and manager/stock/time fixed effects. We include as a control the natural logarithm of the dollar trade volume intermediated by each broker in the last six months and the average dollar volume traded (in the stock) by the manager with the broker in the month in which performance is assessed. T-stats based on robust standard errors, double clustered at both the month and the manager level, are reported in parentheses. Asterisks denote significance levels $(* * *=1 \%$, $* *=5 \%, *=10 \%$ ).

\section{Panel A: Manager Level}

\begin{tabular}{|c|c|c|c|c|c|c|c|c|c|}
\hline & (1) & (2) & (3) & (4) & (5) & (6) & (7) & (8) & (9) \\
\hline & \multicolumn{3}{|c|}{1 Day } & \multicolumn{3}{|c|}{5 Days } & \multicolumn{3}{|c|}{10 Days } \\
\hline Eig. Centrality & $\begin{array}{c}0.892^{* * *} \\
(5.936)\end{array}$ & $\begin{array}{c}0.614^{* * *} \\
(4.182)\end{array}$ & $\begin{array}{c}0.555^{* * *} \\
(3.924)\end{array}$ & $\begin{array}{c}1.847^{* * *} \\
(4.833)\end{array}$ & $\begin{array}{c}1.359 * * * \\
(3.520)\end{array}$ & $\begin{array}{c}1.294^{* * *} \\
(3.372)\end{array}$ & $\begin{array}{c}2.147^{* * *} \\
(4.100)\end{array}$ & $\begin{array}{c}1.434 * * * \\
(2.706)\end{array}$ & $\begin{array}{c}1.619 * * * \\
(3.016)\end{array}$ \\
\hline Broker Volume & $\begin{array}{l}-0.173 \\
(-1.024)\end{array}$ & $\begin{array}{l}0.312^{*} \\
(1.938)\end{array}$ & $\begin{array}{c}0.648 * * * \\
(4.054)\end{array}$ & $\begin{array}{c}0.0446 \\
(0.0914)\end{array}$ & $\begin{array}{c}1.026 * * \\
(2.167)\end{array}$ & $\begin{array}{c}1.641 * * * \\
(3.475)\end{array}$ & $\begin{array}{c}0.154 \\
(0.261)\end{array}$ & $\begin{array}{l}1.370^{* *} \\
(2.362)\end{array}$ & $\begin{array}{c}2.114 * * * \\
(3.590)\end{array}$ \\
\hline Average Trade Size & $\begin{array}{c}-1.699 * * * \\
(-11.58)\end{array}$ & $\begin{array}{c}-2.233^{* * *} \\
(-15.57)\end{array}$ & $\begin{array}{c}-2.995^{* * *} \\
(-17.74)\end{array}$ & $\begin{array}{c}-3.296^{* * *} \\
(-10.79)\end{array}$ & $\begin{array}{c}-4.443^{* * *} \\
(-13.81)\end{array}$ & $\begin{array}{c}-5.535^{* * *} \\
(-14.66)\end{array}$ & $\begin{array}{c}-3.751 * * * \\
(-8.250)\end{array}$ & $\begin{array}{c}-4.861^{* * *} \\
(-9.584)\end{array}$ & $\begin{array}{c}-5.929 * * * \\
(-11.44)\end{array}$ \\
\hline Time FE & Yes & Yes & No & Yes & Yes & No & Yes & Yes & No \\
\hline Manager FE & No & Yes & No & No & Yes & No & No & Yes & No \\
\hline Manager-Time FE & No & No & Yes & No & No & Yes & No & No & Yes \\
\hline Observations & 633,603 & 633,591 & 624,101 & 629,936 & 629,925 & 620,437 & 622,216 & 622,204 & 612,734 \\
\hline R-squared & 0.003 & 0.010 & 0.127 & 0.002 & 0.006 & 0.131 & 0.002 & 0.006 & 0.137 \\
\hline
\end{tabular}

Panel B. Stock Level

Dependent Variable: Value-weighted trading performance

\begin{tabular}{|c|c|c|c|c|c|c|c|c|c|}
\hline & (1) & (2) & (3) & (4) & (5) & (6) & (7) & (8) & (9) \\
\hline & \multicolumn{3}{|c|}{1 Day } & \multicolumn{3}{|c|}{5 Days } & \multicolumn{3}{|c|}{10 Days } \\
\hline Eig. Centrality & $\begin{array}{c}0.525^{* *} \\
(2.242)\end{array}$ & $\begin{array}{c}0.488^{* *} \\
(2.337)\end{array}$ & $\begin{array}{l}0.0513 \\
(0.267)\end{array}$ & $\begin{array}{c}1.193 * * * \\
(3.303)\end{array}$ & $\begin{array}{c}1.120 * * * \\
(3.094)\end{array}$ & $\begin{array}{c}0.975^{* * *} \\
(3.614)\end{array}$ & $\begin{array}{c}1.397 * * \\
(2.018)\end{array}$ & $\begin{array}{l}1.322 * \\
(1.821)\end{array}$ & $\begin{array}{c}1.498^{* *} \\
(2.303)\end{array}$ \\
\hline Broker Volume & $\begin{array}{c}-0.269 \\
(-1.321)\end{array}$ & $\begin{array}{l}-0.225 \\
(-1.176)\end{array}$ & $\begin{array}{l}-0.0859 \\
(-0.676)\end{array}$ & $\begin{array}{l}-1.088^{*} \\
(-1.823)\end{array}$ & $\begin{array}{l}-0.989^{*} \\
(-1.666)\end{array}$ & $\begin{array}{c}-1.397 * * \\
(-1.986)\end{array}$ & $\begin{array}{c}-1.710^{* *} \\
(-2.044)\end{array}$ & $\begin{array}{l}-1.561 * \\
(-1.883)\end{array}$ & $\begin{array}{c}-1.877^{* *} \\
(-2.373)\end{array}$ \\
\hline Average Trade Size & $\begin{array}{c}0.341 * * * \\
(3.165)\end{array}$ & $\begin{array}{c}0.310^{* * *} \\
(3.022)\end{array}$ & $\begin{array}{c}-0.134 \\
(-1.140)\end{array}$ & $\begin{array}{c}0.511^{* *} \\
(2.166)\end{array}$ & $\begin{array}{l}0.437^{*} \\
(1.960)\end{array}$ & $\begin{array}{l}-0.136 \\
(-0.705)\end{array}$ & $\begin{array}{c}0.776^{* *} \\
(2.160)\end{array}$ & $\begin{array}{c}0.703^{* *} \\
(1.988)\end{array}$ & $\begin{array}{c}0.188 \\
(0.827)\end{array}$ \\
\hline Time FE & Yes & No & No & Yes & No & No & Yes & No & No \\
\hline Stock FE & Yes & No & No & Yes & No & No & Yes & No & No \\
\hline Stock-Time FE & No & Yes & No & No & Yes & No & No & Yes & No \\
\hline Manager-Stock-Time FE & No & No & Yes & No & No & Yes & No & No & Yes \\
\hline Observations & $22,494,332$ & $22,472,436$ & $17,740,438$ & $22,361,446$ & $22,339,563$ & $17,620,550$ & $22,093,898$ & $22,071,583$ & $17,362,843$ \\
\hline R-squared & 0.001 & 0.039 & 0.343 & 0.001 & 0.044 & 0.387 & 0.002 & 0.049 & 0.425 \\
\hline
\end{tabular}




\section{Table 4. Broker-Manager Relationships}

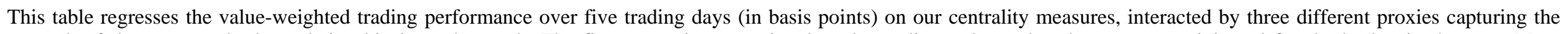

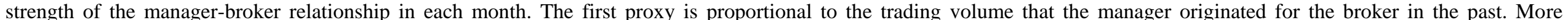

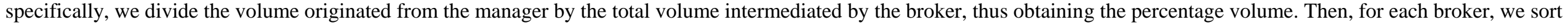

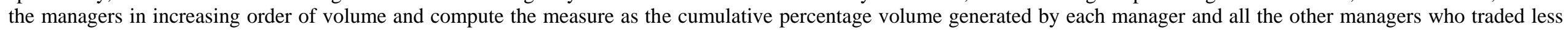

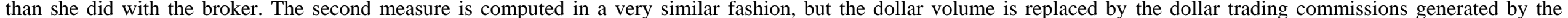

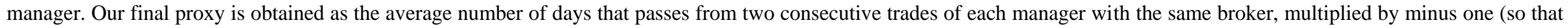

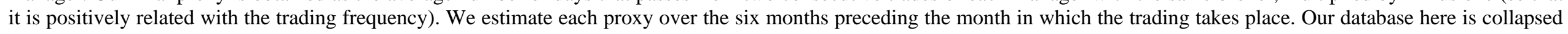

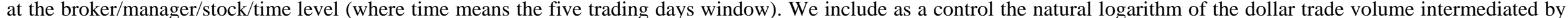

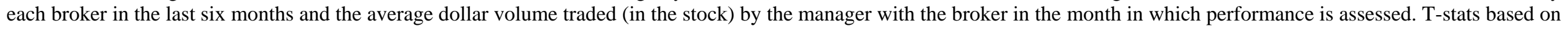
robust standard errors, double-clustered at both the month and the manager level, are reported in parentheses. Asterisks denote significance levels $(* * *=1 \%, * *=5 \%, *=10 \%)$.

Dependent Variable: Value-weighted trading performance over five trading days

\begin{tabular}{|c|c|c|c|c|c|c|c|c|c|c|c|c|}
\hline & (1) & (2) & (3) & (4) & (5) & (6) & (7) & (8) & (9) & $(10)$ & (11) & $(12)$ \\
\hline & \multicolumn{4}{|c|}{ Ranking of Manager-Broker Volume } & \multicolumn{4}{|c|}{ Ranking of Revenue Share } & \multicolumn{4}{|c|}{ Frequency of Manager-Broker Interaction } \\
\hline Centrality $\times$ Relationship Strength & $\begin{array}{c}4.120^{* * *} \\
(2.812)\end{array}$ & $\begin{array}{c}3.779 * * * \\
(2.627)\end{array}$ & $\begin{array}{c}3.896^{* * *} \\
(2.663)\end{array}$ & $\begin{array}{c}3.701 * * * \\
(2.587)\end{array}$ & $\begin{array}{l}2.737^{*} \\
(1.772)\end{array}$ & $\begin{array}{l}2.706^{*} \\
(1.831)\end{array}$ & $\begin{array}{l}2.688^{*} \\
(1.812)\end{array}$ & $\begin{array}{c}2.471 \\
(1.614)\end{array}$ & $\begin{array}{c}0.109^{* *} \\
(2.012)\end{array}$ & $\begin{array}{c}0.108^{* *} \\
(1.978)\end{array}$ & $\begin{array}{c}0.109 * * \\
(1.999)\end{array}$ & $\begin{array}{c}0.115^{* *} \\
(2.120)\end{array}$ \\
\hline Relationship Strength & $\begin{array}{c}-15.18^{* * *} \\
(-4.845)\end{array}$ & $\begin{array}{c}-15.38 * * * \\
(-4.861)\end{array}$ & $\begin{array}{c}-14.61 * * * \\
(-4.718)\end{array}$ & $\begin{array}{c}-12.68 * * * \\
(-4.229)\end{array}$ & $\begin{array}{c}-9.034 * * \\
(-2.459)\end{array}$ & $\begin{array}{c}-9.532^{* * *} \\
(-2.638)\end{array}$ & $\begin{array}{c}-8.893 * * \\
(-2.505)\end{array}$ & $\begin{array}{c}-7.418^{* *} \\
(-2.085)\end{array}$ & $\begin{array}{l}-0.0249 \\
(-0.274)\end{array}$ & $\begin{array}{l}-0.0346 \\
(-0.373)\end{array}$ & $\begin{array}{l}-0.0303 \\
(-0.330)\end{array}$ & $\begin{array}{l}-0.0542 \\
(-0.601)\end{array}$ \\
\hline Centrality & $\begin{array}{l}-2.881 * \\
(-1.742)\end{array}$ & $\begin{array}{c}-2.643 \\
(-1.605)\end{array}$ & $\begin{array}{l}-2.748^{*} \\
(-1.670)\end{array}$ & $\begin{array}{l}-2.885^{*} \\
(-1.837)\end{array}$ & $\begin{array}{l}-1.588 \\
(-1.303)\end{array}$ & $\begin{array}{l}-1.622 \\
(-1.360)\end{array}$ & $\begin{array}{l}-1.615 \\
(-1.347)\end{array}$ & $\begin{array}{l}-1.738 \\
(-1.442)\end{array}$ & $\begin{array}{c}1.129 \\
(1.286)\end{array}$ & $\begin{array}{c}1.072 \\
(1.228)\end{array}$ & $\begin{array}{c}1.059 \\
(1.231)\end{array}$ & $\begin{array}{c}0.767 \\
(0.864)\end{array}$ \\
\hline Broker Volume & $\begin{array}{c}0.151 \\
(0.109)\end{array}$ & $\begin{array}{c}0.00379 \\
(0.00273)\end{array}$ & $\begin{array}{c}0.0304 \\
(0.0221)\end{array}$ & $\begin{array}{l}-0.222 \\
(-0.180)\end{array}$ & $\begin{array}{c}0.0753 \\
(0.0539)\end{array}$ & $\begin{array}{c}-0.0612 \\
(-0.0435)\end{array}$ & $\begin{array}{l}-0.0369 \\
(-0.0265)\end{array}$ & $\begin{array}{c}-0.272 \\
(-0.219)\end{array}$ & $\begin{array}{l}-0.309 \\
(-0.218)\end{array}$ & $\begin{array}{l}-0.395 \\
(-0.277)\end{array}$ & $\begin{array}{l}-0.412 \\
(-0.292)\end{array}$ & $\begin{array}{l}-0.604 \\
(-0.480)\end{array}$ \\
\hline Controls & No & Yes & No & No & No & Yes & No & No & No & Yes & No & No \\
\hline Time FE & Yes & Yes & Yes & No & Yes & Yes & Yes & No & Yes & Yes & Yes & No \\
\hline Broker FE & Yes & Yes & Yes & Yes & Yes & Yes & Yes & Yes & Yes & Yes & Yes & Yes \\
\hline Stock FE & No & No & Yes & No & No & No & Yes & No & No & No & Yes & No \\
\hline Stock-Time FE & No & No & No & Yes & No & No & No & Yes & No & $\mathrm{No}$ & No & Yes \\
\hline Observations & $34,734,096$ & $34,452,536$ & $34,734,035$ & $34,511,266$ & $34,734,096$ & $34,452,536$ & $34,734,035$ & $34,511,266$ & $34,561,431$ & $34,280,954$ & $34,561,371$ & $34,337,716$ \\
\hline R-squared & 0.003 & 0.003 & 0.003 & 0.107 & 0.003 & 0.003 & 0.003 & 0.107 & 0.003 & 0.003 & 0.003 & 0.107 \\
\hline
\end{tabular}




\section{Table 5. Large Trade}

This table relates the trading behavior of followers after a large trade. The followers are all the managers, different from the one who generates the large trade (i.e. the originator), who trade the stock with the same broker who intermediates the large trade. We divide the sample in three sub-periods: the two trading weeks preceding the week in which the large trade was made (before); the period in which the large trade has started, but the originator is still trading in the same direction at a sustained pace (competition); and the period after the originator has stopped trading, up to four weeks after the large trade week in which he initiated the trade sequence (week 1 to 4). When we refer to week one after the large trade, we identify the period that ranges from end of the competition period to the end of the first week after the large trade week; in a similar way, when we refer to week two to four. In the first two columns, the dependent variable is a dummy that takes value one if the follower trades in the same direction as the originator and zero otherwise, while in columns 3-4 it is the $\log$ of the net dollar volume of the followers. Panel B reports the same specification but interacting the time dummies with the centrality measure. We include as a control the natural logarithm of the dollar trade volume intermediated by each broker in the last six months and the natural logarithm of the large trade volume, taken in absolute value (as before, scaled by the trading volume in CRSP). The most conservative specifications include stock-time and manager-time fixed effects. Panel $\mathrm{C}$ uses as dependent variable an indicator for whether the manager is executing the first trade after the large trade in the same direction as the Originator during the Competition week or Week 1. The dummy takes a value of 0 if the follower's first trade is in the opposite direction or it is in the same direction but after Week 1. The explanatory variables are dummy variables (Strong Relation) that identify, among all the managers who are trading the stock, the ones who have a stronger relationship with the broker. We use four different proxies for the strength of the manager-broker relationship. The first three proxies identify the top quarter of the distributions of the three following variables. First, we consider the trading volume that the manager originated for the broker in the past. More specifically, we divide the volume originated from the manager by the total volume intermediated by the broker, thus obtaining the percentage volume. Then, for each broker, we sort the managers in increasing order of volume and compute the measure as the cumulative percentage volume generated by each manager and all the other managers who traded less than she did with the broker. The second measure is computed in a very similar fashion, but the dollar volume is replaced by the dollar trading commissions generated by the manager. The third measure is obtained as the average number of days that passes from two consecutive trades of each manager with the same broker, multiplied by minus one (so that it is positively related with the trading frequency). We estimate each proxy over the six months preceding the month in which the trading takes place. The last proxy is a dummy that identifies an affiliation relationship between a manager and the broker. T-stats based on robust standard errors, clustered at both the month and the manager level (manager level only in Panel C), are reported in parentheses. Asterisks denote significance levels $(* * *=1 \%, * *=5 \%, *=10 \%)$. 


\section{Panel A}

\begin{tabular}{|c|c|c|c|c|}
\hline & (1) & (2) & (3) & (4) \\
\hline & \multicolumn{2}{|c|}{$\begin{array}{l}\text { Dummy }=1 \text { if follower trades in the } \\
\text { same direction as the informed trade }\end{array}$} & \multicolumn{2}{|c|}{$\begin{array}{l}\text { Log of dollar imbalances from } \\
\text { followers }\end{array}$} \\
\hline Competition & $\begin{array}{c}0.0667 * * * \\
(5.106)\end{array}$ & $\begin{array}{c}0.0633^{* * *} \\
(4.847)\end{array}$ & $\begin{array}{c}1.615^{* * *} \\
(4.991)\end{array}$ & $\begin{array}{c}1.540 * * * \\
(4.754)\end{array}$ \\
\hline Week 1 & $\begin{array}{c}0.00256^{* * *} \\
(3.225)\end{array}$ & $\begin{array}{c}0.00255^{* * *} \\
(3.169)\end{array}$ & $\begin{array}{c}0.0616^{* * *} \\
(3.138)\end{array}$ & $\begin{array}{c}0.0616^{* * *} \\
(3.102)\end{array}$ \\
\hline Week 2 & $\begin{array}{l}-0.00138 \\
(-1.641)\end{array}$ & $\begin{array}{l}-0.00124 \\
(-1.533)\end{array}$ & $\begin{array}{l}-0.0315^{*} \\
(-1.648)\end{array}$ & $\begin{array}{l}-0.0278 \\
(-1.516)\end{array}$ \\
\hline Week 3 & $\begin{array}{c}-0.00184 * \\
(-1.718)\end{array}$ & $\begin{array}{l}-0.00171 \\
(-1.646)\end{array}$ & $\begin{array}{c}-0.0468^{* *} \\
(-1.990)\end{array}$ & $\begin{array}{l}-0.0437 * \\
(-1.911)\end{array}$ \\
\hline Week 4 & $\begin{array}{c}-0.00260 * * \\
(-2.038)\end{array}$ & $\begin{array}{c}-0.00241 * * \\
(-1.976)\end{array}$ & $\begin{array}{c}-0.0614^{* *} \\
(-2.083)\end{array}$ & $\begin{array}{c}-0.0575^{* *} \\
(-2.028)\end{array}$ \\
\hline Controls & Yes & Yes & Yes & Yes \\
\hline Manager FE & Yes & No & Yes & No \\
\hline Manager-Time FE & No & Yes & No & Yes \\
\hline Stock-Time FE & Yes & Yes & Yes & Yes \\
\hline Observations & $21,019,798$ & $20,999,192$ & $20,964,660$ & $20,944,053$ \\
\hline R-squared & 0.079 & 0.093 & 0.077 & 0.092 \\
\hline
\end{tabular}


Panel B: Central vs Peripheral

(1)

(2)

(3)

(4)

Dummy $=1$ if follower trades in the same direction as the informed trade

Log of dollar imbalances from followers

\begin{tabular}{|c|c|c|c|c|}
\hline Centrality $\times$ Competition & $\begin{array}{c}0.0267^{* * *} \\
(7.990)\end{array}$ & $\begin{array}{c}0.0265^{* * *} \\
(7.842)\end{array}$ & $\begin{array}{c}0.672 * * * \\
(7.683)\end{array}$ & $\begin{array}{c}0.666^{* * *} \\
(7.555)\end{array}$ \\
\hline Centrality $\times$ Week 1 & $\begin{array}{c}0.000486 \\
(0.657)\end{array}$ & $\begin{array}{c}0.000567 \\
(0.762)\end{array}$ & $\begin{array}{l}0.0144 \\
(0.827)\end{array}$ & $\begin{array}{l}0.0166 \\
(0.951)\end{array}$ \\
\hline Centrality $\times$ Week 2 & $\begin{array}{c}-0.00226^{* * *} \\
(-3.311)\end{array}$ & $\begin{array}{c}-0.00216^{* * *} \\
(-3.222)\end{array}$ & $\begin{array}{c}-0.0500^{* * *} \\
(-3.086)\end{array}$ & $\begin{array}{c}-0.0478^{* * *} \\
(-3.001)\end{array}$ \\
\hline Centrality $\times$ Week 3 & $\begin{array}{c}-0.00281^{* * *} \\
(-3.271)\end{array}$ & $\begin{array}{c}-0.00284^{* * *} \\
(-3.347)\end{array}$ & $\begin{array}{c}-0.0738^{* * *} \\
(-3.761)\end{array}$ & $\begin{array}{c}-0.0747 * * * \\
(-3.826)\end{array}$ \\
\hline Centrality $\times$ Week 4 & $\begin{array}{c}-0.00410^{* * *} \\
(-3.552)\end{array}$ & $\begin{array}{c}-0.00400^{* * *} \\
(-3.475)\end{array}$ & $\begin{array}{c}-0.101^{* * *} \\
(-3.668)\end{array}$ & $\begin{array}{c}-0.0997 * * * \\
(-3.602)\end{array}$ \\
\hline Centrality & $\begin{array}{c}0.00371^{* *} \\
(2.451)\end{array}$ & $\begin{array}{c}0.00324 * * \\
(1.994)\end{array}$ & $\begin{array}{c}0.101 * * * \\
(3.941)\end{array}$ & $\begin{array}{c}0.0919^{* * *} \\
(3.713)\end{array}$ \\
\hline Competition & $\begin{array}{c}0.00442 \\
(0.337)\end{array}$ & $\begin{array}{c}0.00155 \\
(0.121)\end{array}$ & $\begin{array}{l}0.0480 \\
(0.146)\end{array}$ & $\begin{array}{l}-0.0126 \\
(-0.0390)\end{array}$ \\
\hline Week 1 & $\begin{array}{c}0.00147 \\
(0.871)\end{array}$ & $\begin{array}{c}0.00129 \\
(0.763)\end{array}$ & $\begin{array}{l}0.0298 \\
(0.757)\end{array}$ & $\begin{array}{l}0.0249 \\
(0.639)\end{array}$ \\
\hline Week 2 & $\begin{array}{c}0.00351^{* *} \\
(2.295)\end{array}$ & $\begin{array}{c}0.00344 * * \\
(2.312)\end{array}$ & $\begin{array}{c}0.0765 * * \\
(2.206)\end{array}$ & $\begin{array}{c}0.0756^{* *} \\
(2.232)\end{array}$ \\
\hline Week 3 & $\begin{array}{c}0.00422^{* *} \\
(2.234)\end{array}$ & $\begin{array}{c}0.00443^{* *} \\
(2.342)\end{array}$ & $\begin{array}{c}0.112 * * * \\
(2.753)\end{array}$ & $\begin{array}{c}0.117 * * * \\
(2.867)\end{array}$ \\
\hline Week 4 & $\begin{array}{c}0.00621 * * * \\
(2.644)\end{array}$ & $\begin{array}{c}0.00619 * * * \\
(2.613)\end{array}$ & $\begin{array}{c}0.156^{* * *} \\
(2.895)\end{array}$ & $\begin{array}{c}0.157 * * * \\
(2.872)\end{array}$ \\
\hline Controls & Yes & Yes & Yes & Yes \\
\hline Manager FE & Yes & No & Yes & No \\
\hline Manager-Time FE & No & Yes & No & Yes \\
\hline Stock-Time FE & Yes & Yes & Yes & Yes \\
\hline Observations & $21,019,798$ & $20,999,192$ & $20,964,660$ & $20,944,053$ \\
\hline R-squared & 0.079 & 0.093 & 0.077 & 0.092 \\
\hline
\end{tabular}




\section{Panel C: Relationship Strength}

Dependent Variable is Dummy for a trade in the same direction as the Originator after the large trade during Competition or Week 1

\begin{tabular}{|c|c|c|c|c|c|c|c|c|c|c|c|c|}
\hline \multirow[b]{2}{*}{ Strength of relationship proxy: } & (1) & (2) & (3) & (4) & (5) & (6) & (7) & (8) & (9) & (10) & (11) & (12) \\
\hline & \multicolumn{3}{|c|}{$\begin{array}{c}\text { Ranking of Manager-Broker } \\
\text { Volume }\end{array}$} & \multicolumn{3}{|c|}{ Ranking of Revenue Share } & \multicolumn{3}{|c|}{$\begin{array}{c}\text { Frequency of Manager-Broker } \\
\text { Interaction }\end{array}$} & \multicolumn{3}{|c|}{ Broker - Manager Affiliation } \\
\hline Strong Relation & $\begin{array}{l}0.0722^{* * *} \\
(8.682)\end{array}$ & $\begin{array}{c}0.0413^{* * *} \\
(8.932)\end{array}$ & $\begin{array}{c}0.0821 * * * \\
(8.554)\end{array}$ & $\begin{array}{c}0.0790^{* * *} \\
(10.81)\end{array}$ & $\begin{array}{l}0.0519 * * * \\
(12.18)\end{array}$ & $\begin{array}{c}0.0891 * * * \\
(10.56)\end{array}$ & $\begin{array}{c}0.0794 * * * \\
(8.495)\end{array}$ & $\begin{array}{c}0.0481 * * * \\
(8.891)\end{array}$ & $\begin{array}{c}0.0860^{* * *} \\
(9.123)\end{array}$ & $\begin{array}{c}0.108 * * * \\
(2.578)\end{array}$ & $\begin{array}{c}0.0796^{* *} \\
(2.344)\end{array}$ & $\begin{array}{c}0.0975^{* * *} \\
(4.468)\end{array}$ \\
\hline Constant & $\begin{array}{l}0.243 * * * \\
(54.28)\end{array}$ & & & $\begin{array}{l}0.241 * * * \\
(51.45)\end{array}$ & & & $\begin{array}{l}0.237 * * * \\
(60.89)\end{array}$ & & & $\begin{array}{c}0.264 * * * \\
(34.39)\end{array}$ & & \\
\hline Mgr FE & No & Yes & No & No & Yes & No & No & Yes & No & No & Yes & No \\
\hline Stock FE & No & Yes & No & No & Yes & No & No & Yes & No & No & Yes & No \\
\hline Time FE & No & Yes & No & No & Yes & No & No & Yes & No & No & Yes & No \\
\hline Stock-Time FE & No & No & Yes & No & No & Yes & No & No & Yes & No & No & Yes \\
\hline Observations & $5,599,032$ & $5,598,851$ & $5,453,613$ & $5,599,032$ & $5,598,851$ & $5,453,613$ & $5,599,032$ & $5,598,851$ & $5,453,613$ & $5,599,032$ & $5,598,851$ & $5,453,613$ \\
\hline R-squared & 0.006 & 0.023 & 0.184 & 0.007 & 0.024 & 0.186 & 0.007 & 0.023 & 0.185 & 0.001 & 0.022 & 0.178 \\
\hline
\end{tabular}




\section{Table 6. Unusual Stocks for Followers}

This table relates the trading behavior of followers after a large trade. The followers are all the managers, different from the one who generates the large trade (i.e. the originator), who trade the stock with the same broker who intermediates the large trade. We restrict attention to stocks that have been above the median of trading volume for the originator in the previous six months and in the bottom decile for the followers. We divide the sample in three sub-periods: the two trading weeks preceding the week in which the large trade was made (before); the period in which the large trade has started, but the originator is still trading in the same direction at a sustained pace (competition); and the period after the originator has stopped trading, up to four weeks after the large trade week in which he initiated the trade sequence (week 1 to 4). When we refer to week one after the large trade, we identify the period that ranges from end of the competition period to the end of the first week after the large trade week; in a similar way, when we refer to week two to four. In the first two columns, the dependent variable is a dummy that takes value one if the follower trades in the same direction as the originator and zero otherwise, while in columns 3-4 it is the log of the net dollar volume of the followers. Panel B reports the same specification but interacting the time dummies with the centrality measure. We include as a control the natural logarithm of the dollar trade volume intermediated by each broker in the last six months and the natural logarithm of the large trade volume, taken in absolute value (as before, scaled by the trading volume in CRSP). The most conservative specifications include stock-time and manager-time fixed effects. T-stats based on robust standard errors, double-clustered at both the month and the manager level, are reported in parentheses. Asterisks denote significance levels $(* * *=1 \%, * *=5 \%, *=10 \%)$.

\section{Panel A}

\begin{tabular}{|c|c|c|c|c|}
\hline & (1) & (2) & (3) & (4) \\
\hline & \multicolumn{2}{|c|}{$\begin{array}{l}\text { Dummy }=1 \text { if follower trades in the } \\
\text { same direction as the informed trade }\end{array}$} & \multicolumn{2}{|c|}{$\begin{array}{l}\text { Log of dollar imbalances from } \\
\text { followers }\end{array}$} \\
\hline Competition & $\begin{array}{c}0.0829 * * * \\
(6.727)\end{array}$ & $\begin{array}{c}0.0784 * * * \\
(5.798)\end{array}$ & $\begin{array}{c}1.882^{* * *} \\
(6.824)\end{array}$ & $\begin{array}{c}1.734 * * * \\
(5.795)\end{array}$ \\
\hline Week 1 & $\begin{array}{c}0.00539 \\
(1.079)\end{array}$ & $\begin{array}{c}0.00695 \\
(1.301)\end{array}$ & $\begin{array}{c}0.104 \\
(0.885)\end{array}$ & $\begin{array}{c}0.112 \\
(0.902)\end{array}$ \\
\hline Week 2 & $\begin{array}{c}-0.00599 \\
(-1.073)\end{array}$ & $\begin{array}{c}-0.00613 \\
(-0.944)\end{array}$ & $\begin{array}{l}-0.163 \\
(-1.222)\end{array}$ & $\begin{array}{l}-0.196 \\
(-1.295)\end{array}$ \\
\hline Week 3 & $\begin{array}{c}0.000180 \\
(0.0288)\end{array}$ & $\begin{array}{c}-0.00176 \\
(-0.232)\end{array}$ & $\begin{array}{l}0.000869 \\
(0.00614)\end{array}$ & $\begin{array}{l}-0.0684 \\
(-0.417)\end{array}$ \\
\hline Week 4 & $\begin{array}{c}-0.000941 \\
(-0.120)\end{array}$ & $\begin{array}{l}-0.00945 \\
(-0.994)\end{array}$ & $\begin{array}{l}-0.0286 \\
(-0.170)\end{array}$ & $\begin{array}{l}-0.249 \\
(-1.276)\end{array}$ \\
\hline Controls & Yes & Yes & Yes & Yes \\
\hline Manager FE & Yes & No & Yes & No \\
\hline Manager-Time FE & No & Yes & No & Yes \\
\hline Stock-Time FE & Yes & Yes & Yes & Yes \\
\hline Observations & 280,188 & 263,917 & 279,840 & 263,563 \\
\hline R-squared & 0.520 & 0.609 & 0.519 & 0.612 \\
\hline
\end{tabular}


Panel B: Central vs Peripheral

(1)

Dummy $=1$ if follower trades in the same direction as the informed trade

\begin{tabular}{|c|c|c|c|c|}
\hline Centrality $\times$ Competition & $\begin{array}{c}0.0243 * * * \\
(4.575)\end{array}$ & $\begin{array}{c}0.0226 * * * \\
(3.811)\end{array}$ & $\begin{array}{c}0.582 * * * \\
(4.612)\end{array}$ & $\begin{array}{c}0.545^{* * *} \\
(3.959)\end{array}$ \\
\hline Centrality $\times$ Week 1 & $\begin{array}{c}0.00570 \\
(1.468)\end{array}$ & $\begin{array}{c}0.00237 \\
(0.562)\end{array}$ & $\begin{array}{c}0.137 \\
(1.479)\end{array}$ & $\begin{array}{l}0.0726 \\
(0.726)\end{array}$ \\
\hline Centrality $\times$ Week 2 & $\begin{array}{c}-0.00437 \\
(-0.929)\end{array}$ & $\begin{array}{c}-0.0107 * * \\
(-1.975)\end{array}$ & $\begin{array}{l}-0.0969 \\
(-0.906)\end{array}$ & $\begin{array}{l}-0.224 * \\
(-1.866)\end{array}$ \\
\hline Centrality $\times$ Week 3 & $\begin{array}{c}-0.0113^{* *} \\
(-2.326)\end{array}$ & $\begin{array}{c}-0.0191 * * * \\
(-3.445)\end{array}$ & $\begin{array}{c}-0.262^{* *} \\
(-2.434)\end{array}$ & $\begin{array}{c}-0.426 * * * \\
(-3.491)\end{array}$ \\
\hline Centrality $\times$ Week 4 & $\begin{array}{c}-0.0152^{* *} \\
(-2.309)\end{array}$ & $\begin{array}{c}-0.0197 * * \\
(-2.501)\end{array}$ & $\begin{array}{c}-0.310^{* *} \\
(-2.244)\end{array}$ & $\begin{array}{c}-0.367 * * \\
(-2.273)\end{array}$ \\
\hline Centrality & $\begin{array}{c}0.00813^{* *} \\
(2.469)\end{array}$ & $\begin{array}{c}0.00776^{*} \\
(1.940)\end{array}$ & $\begin{array}{c}0.199 * * * \\
(2.609)\end{array}$ & $\begin{array}{c}0.190 * * \\
(2.001)\end{array}$ \\
\hline Competition & $\begin{array}{l}0.0235 \\
(1.483)\end{array}$ & $\begin{array}{l}0.0224 \\
(1.294)\end{array}$ & $\begin{array}{c}0.461 \\
(1.268)\end{array}$ & $\begin{array}{c}0.390 \\
(0.996)\end{array}$ \\
\hline Week 1 & $\begin{array}{c}-0.00710 \\
(-0.687)\end{array}$ & $\begin{array}{c}0.00151 \\
(0.137)\end{array}$ & $\begin{array}{l}-0.195 \\
(-0.798)\end{array}$ & $\begin{array}{l}-0.0521 \\
(-0.201)\end{array}$ \\
\hline Week 2 & $\begin{array}{c}0.00329 \\
(0.283)\end{array}$ & $\begin{array}{l}0.0169 \\
(1.256)\end{array}$ & $\begin{array}{l}0.0425 \\
(0.159)\end{array}$ & $\begin{array}{c}0.286 \\
(0.962)\end{array}$ \\
\hline Week 3 & $\begin{array}{c}0.0241 * \\
(1.863)\end{array}$ & $\begin{array}{c}0.0390 * * * \\
(2.636)\end{array}$ & $\begin{array}{l}0.557 * \\
(1.938)\end{array}$ & $\begin{array}{c}0.841 * * * \\
(2.642)\end{array}$ \\
\hline Week 4 & $\begin{array}{c}0.0310^{*} \\
(1.824)\end{array}$ & $\begin{array}{l}0.0323 \\
(1.569)\end{array}$ & $\begin{array}{l}0.624^{*} \\
(1.800)\end{array}$ & $\begin{array}{c}0.530 \\
(1.319)\end{array}$ \\
\hline Controls & Yes & Yes & Yes & Yes \\
\hline Manager FE & Yes & No & Yes & No \\
\hline Manager-Time FE & No & Yes & No & Yes \\
\hline Stock-Time FE & Yes & Yes & Yes & Yes \\
\hline Observations & 280,188 & 263,917 & 279,840 & 263,563 \\
\hline R-squared & 0.520 & 0.609 & 0.520 & 0.612 \\
\hline
\end{tabular}

Log of dollar imbalances from followers
(3) (4) 


\section{Table 7. Large Trade - Exclude Earnings Announcements and Recommendation Changes}

This table relates the trading behavior of followers after a large trade. In this case we exclude large trades initiated during a window of four weeks (two weeks before and two weeks after) around earnings announcements or changes in analyst recommendations. As before, the followers are all the managers, different from the one who generates the large trade (i.e. the originator), who trade the stock with the same broker who intermediates the large trade. We divide the sample in three sub-periods: the two trading weeks preceding the week in which the large trade was made (before); the period in which the large trade has started, but the originator is still trading in the same direction at a sustained pace (competition); and the period after the originator has stopped trading, up to four weeks after the large trade week in which he initiated the trade sequence (week 1 to 4 ). When we refer to week one after the large trade, we identify the period that ranges from end of the competition period to the end of the first week after the large trade week; in a similar way, when we refer to week two to four. In the first two columns, the dependent variable is a dummy that takes value one if the follower trades in the same direction as the originator and zero otherwise, while in columns 3-4 it is the log of the net dollar volume of the followers. Panel B reports the same specification but interacting the time dummies with the centrality measure. We include as a control the natural logarithm of the dollar trade volume intermediated by each broker in the last six months and the natural logarithm of the large trade volume, taken in absolute value (as before, scaled by the trading volume in CRSP). The most conservative specifications include stock-time and manager-time fixed effects. T-stats based on robust standard errors, double-clustered at both the month and the manager level, are reported in parentheses. Asterisks denote significance levels $(* * *=1 \%, * *=5 \%, *=10 \%)$.

\section{Panel A}

\begin{tabular}{|c|c|c|c|c|}
\hline \multirow[b]{3}{*}{ Competition } & (1) & (2) & (3) & (4) \\
\hline & \multicolumn{2}{|c|}{$\begin{array}{l}\text { Dummy }=1 \text { if follower trades in the } \\
\text { same direction as the informed trade }\end{array}$} & \multicolumn{2}{|c|}{$\begin{array}{c}\text { Log of dollar imbalances from } \\
\text { followers }\end{array}$} \\
\hline & $\begin{array}{c}0.0633^{* * *} \\
(5.142)\end{array}$ & $\begin{array}{c}0.0595^{* * * *} \\
(4.852)\end{array}$ & $\begin{array}{c}1.531 * * * \\
(5.031)\end{array}$ & $\begin{array}{c}1.447 * * * \\
(4.764)\end{array}$ \\
\hline Week 1 & $\begin{array}{l}0.00300^{* * *} \\
(2.766)\end{array}$ & $\begin{array}{c}0.00308^{* * *} \\
(2.799)\end{array}$ & $\begin{array}{c}0.0711 * * * \\
(2.683)\end{array}$ & $\begin{array}{c}0.0720^{* * *} \\
(2.714)\end{array}$ \\
\hline Week 2 & $\begin{array}{c}-0.000770 \\
(-0.600)\end{array}$ & $\begin{array}{c}-0.000480 \\
(-0.383)\end{array}$ & $\begin{array}{l}-0.0138 \\
(-0.472)\end{array}$ & $\begin{array}{c}-0.00782 \\
(-0.274)\end{array}$ \\
\hline Week 3 & $\begin{array}{c}-0.00193 \\
(-1.306)\end{array}$ & $\begin{array}{c}-0.00180 \\
(-1.213)\end{array}$ & $\begin{array}{l}-0.0402 \\
(-1.233)\end{array}$ & $\begin{array}{l}-0.0380 \\
(-1.154)\end{array}$ \\
\hline Week 4 & $\begin{array}{l}-0.00206 \\
(-1.226)\end{array}$ & $\begin{array}{l}-0.00187 \\
(-1.122)\end{array}$ & $\begin{array}{l}-0.0446 \\
(-1.171)\end{array}$ & $\begin{array}{l}-0.0418 \\
(-1.091)\end{array}$ \\
\hline Controls & Yes & Yes & Yes & Yes \\
\hline Manager FE & Yes & No & Yes & No \\
\hline Manager-Time FE & No & Yes & No & Yes \\
\hline Stock-Time FE & Yes & Yes & Yes & Yes \\
\hline Observations & $8,510,854$ & $8,485,503$ & $8,487,772$ & $8,462,404$ \\
\hline R-squared & 0.114 & 0.138 & 0.111 & 0.136 \\
\hline
\end{tabular}


Panel B: Central vs Peripheral

\begin{tabular}{|c|c|c|c|c|}
\hline \multirow{3}{*}{ Centrality $\times$ Competition } & \multirow{2}{*}{\multicolumn{2}{|c|}{$\begin{array}{c}\text { (1) } \\
\text { Dummy=1 if follower trades in the } \\
\text { same direction as the informed trade }\end{array}$}} & \multirow{2}{*}{\multicolumn{2}{|c|}{$\begin{array}{l}\text { Log of dollar imbalances from } \\
\text { followers }\end{array}$}} \\
\hline & & & & \\
\hline & $\begin{array}{c}0.0248^{* * *} \\
(7.438)\end{array}$ & $\begin{array}{c}0.0245^{* * *} \\
(7.256)\end{array}$ & $\begin{array}{c}0.628^{* * *} \\
(7.143)\end{array}$ & $\begin{array}{c}0.620^{* * *} \\
(6.981)\end{array}$ \\
\hline Centrality $\times$ Week 1 & $\begin{array}{c}0.00115 \\
(1.213)\end{array}$ & $\begin{array}{c}0.00126 \\
(1.279)\end{array}$ & $\begin{array}{l}0.0304 \\
(1.372)\end{array}$ & $\begin{array}{l}0.0337 \\
(1.488)\end{array}$ \\
\hline Centrality $\times$ Week 2 & $\begin{array}{c}-0.00119 \\
(-1.214)\end{array}$ & $\begin{array}{c}-0.00127 \\
(-1.303)\end{array}$ & $\begin{array}{l}-0.0278 \\
(-1.223)\end{array}$ & $\begin{array}{l}-0.0298 \\
(-1.326)\end{array}$ \\
\hline Centrality $\times$ Week 3 & $\begin{array}{c}-0.00283 * * * \\
(-2.771)\end{array}$ & $\begin{array}{c}-0.00278^{* * *} \\
(-2.728)\end{array}$ & $\begin{array}{c}-0.0782^{* * *} \\
(-3.323)\end{array}$ & $\begin{array}{c}-0.0769 * * * \\
(-3.281)\end{array}$ \\
\hline Centrality $\times$ Week 4 & $\begin{array}{c}-0.00298 * * \\
(-2.527)\end{array}$ & $\begin{array}{c}-0.00278^{* *} \\
(-2.382)\end{array}$ & $\begin{array}{c}-0.0827 * * * \\
(-2.982)\end{array}$ & $\begin{array}{c}-0.0786 * * * \\
(-2.857)\end{array}$ \\
\hline Centrality & $\begin{array}{c}0.00429 * * * \\
(2.758)\end{array}$ & $\begin{array}{c}0.00393^{* *} \\
(2.321)\end{array}$ & $\begin{array}{c}0.117 * * * \\
(4.308)\end{array}$ & $\begin{array}{c}0.110^{* * *} \\
(4.164)\end{array}$ \\
\hline Competition & $\begin{array}{c}0.00539 \\
(0.420)\end{array}$ & $\begin{array}{c}0.00237 \\
(0.189)\end{array}$ & $\begin{array}{l}0.0667 \\
(0.206)\end{array}$ & $\begin{array}{c}0.00240 \\
(0.00759)\end{array}$ \\
\hline Week 1 & $\begin{array}{c}0.000472 \\
(0.216)\end{array}$ & $\begin{array}{c}0.000312 \\
(0.143)\end{array}$ & $\begin{array}{l}0.00444 \\
(0.0870)\end{array}$ & $\begin{array}{l}-0.00190 \\
(-0.0375)\end{array}$ \\
\hline Week 2 & $\begin{array}{c}0.00184 \\
(0.734)\end{array}$ & $\begin{array}{c}0.00231 \\
(0.909)\end{array}$ & $\begin{array}{l}0.0473 \\
(0.822)\end{array}$ & $\begin{array}{l}0.0580 \\
(0.992)\end{array}$ \\
\hline Week 3 & $\begin{array}{c}0.00422 \\
(1.552)\end{array}$ & $\begin{array}{c}0.00427 \\
(1.533)\end{array}$ & $\begin{array}{c}0.130 * * \\
(2.111)\end{array}$ & $\begin{array}{c}0.130^{* *} \\
(2.061)\end{array}$ \\
\hline Week 4 & $\begin{array}{c}0.00442 \\
(1.574)\end{array}$ & $\begin{array}{c}0.00419 \\
(1.437)\end{array}$ & $\begin{array}{c}0.135^{* *} \\
(2.089)\end{array}$ & $\begin{array}{l}0.130 * \\
(1.926)\end{array}$ \\
\hline Controls & Yes & Yes & Yes & Yes \\
\hline Manager FE & Yes & No & Yes & No \\
\hline Manager-Time FE & No & Yes & No & Yes \\
\hline Stock-Time FE & Yes & Yes & Yes & Yes \\
\hline Observations & $8,510,854$ & $8,485,503$ & $8,487,772$ & $8,462,404$ \\
\hline R-squared & 0.114 & 0.138 & 0.111 & 0.136 \\
\hline
\end{tabular}




\section{Table 8. Placebo: Shift of Timeline and Behavior with other Brokers}

In this table we present the results of two placebo tests. In the first (Panel A and B) we analyze the trading behavior of followers, shifting the timeline by eight weeks before the original large trade week (our shifted large trade week). As before, the followers are all the managers, different from the one who generates the large trade (i.e. the originator), who trade the stock with the same broker who intermediates the large trade. In the second placebo test (Panel C and D), instead, we keep the original timeline without any shift, but in this case we analyze the trading behavior of followers when trading with brokers different from the one who intermediated the large trade. Our definition of follower does not change from the usual one, therefore the composition of the followers group is unchanged. The structure of both tests is still the same that we adopt in the baseline analysis. We divide the sample in three sub-periods: the two trading weeks preceding the (shifted) large trade week (before); the (shifted) large trade week (competition); and the period up to four weeks after the (shifted) large trade week (week 1 to 4 ). In the first two columns, the dependent variable is a dummy that takes value one if the follower trades in the same direction as the originator and zero otherwise, while in columns 3-4 it is the log of the net dollar volume of the followers. We include as a control the natural logarithm of the dollar trade volume intermediated by each broker in the last six months and the natural logarithm of the large trade volume, taken in absolute value (as before, scaled by the trading volume in CRSP). The most conservative specifications include stock-time and manager-time fixed effects. T-stats based on robust standard errors, double-clustered at both the month and the manager level, are reported in parentheses. Asterisks denote significance levels $(* * *=1 \%, * *=5 \%, *=10 \%)$.

\section{Panel A: Timeline Shift}

(1)

Dummy $=1$ if follower trades in the same direction as the informed trade
(3)

(4)

\begin{tabular}{lcccc} 
& $\begin{array}{c}\text { Dummy }=1 \text { if follower trades in the } \\
\text { same direction as the informed trade }\end{array}$ & $\begin{array}{c}\text { Log of dollar imbalances from } \\
\text { followers }\end{array}$ \\
Competition & -0.000285 & -0.000177 & -0.00887 & -0.00646 \\
Week 1 & $(-0.494)$ & $(-0.304)$ & $(-0.712)$ & $(-0.515)$ \\
& -0.000550 & -0.000425 & -0.0118 & -0.00899 \\
Week 2 & $(-0.576)$ & $(-0.455)$ & $(-0.565)$ & $(-0.438)$ \\
& 0.000378 & 0.000398 & 0.00755 & 0.00766 \\
Week 3 & $(0.399)$ & $(0.432)$ & $(0.355)$ & $(0.371)$ \\
& $7.18 \mathrm{e}-05$ & $-5.20 \mathrm{e}-05$ & 0.000200 & -0.00277 \\
Week 4 & $(0.0783)$ & $(-0.0574)$ & $(0.0103)$ & $(-0.145)$ \\
& 0.000123 & 0.000132 & 0.00397 & 0.00322 \\
& $(0.101)$ & $(0.111)$ & $(0.154)$ & $(0.128)$ \\
Controls & & & & Yes \\
Manager FE & Yes & Yes & Yes & No \\
Manager-Time FE & Yes & No & No & Yes \\
Stock-Time FE & No & Yes & Yes & Yes \\
& Yes & Yes & & \\
Observations & $22,271,277$ & $22,251,239$ & $22,214,272$ & $22,194,225$ \\
R-squared & 0.071 & 0.084 & 0.069 & 0.082 \\
\hline
\end{tabular}


(1)

Dummy $=1$ if follower trades in the same direction as the informed trade
(3)

(4)

Log of dollar imbalances from followers

\begin{tabular}{|c|c|c|c|c|}
\hline \multirow{2}{*}{ Centrality $\times$ Competition } & $0.000957 *$ & $0.000871 *$ & 0.0176 & 0.0163 \\
\hline & (1.785) & (1.658) & $(1.441)$ & $(1.352)$ \\
\hline \multirow[t]{2}{*}{ Centrality $\times$ Week 1} & 0.000749 & 0.000710 & 0.0150 & 0.0143 \\
\hline & (1.331) & (1.294) & $(1.129)$ & $(1.097)$ \\
\hline \multirow[t]{2}{*}{ Centrality $\times$ Week 2} & $0.00188^{* * *}$ & $0.00175^{* * *}$ & $0.0388^{* * *}$ & $0.0366^{* * *}$ \\
\hline & (3.325) & (3.187) & $(2.901)$ & $(2.820)$ \\
\hline \multirow[t]{2}{*}{ Centrality $\times$ Week 3} & $0.00160^{* *}$ & $0.00159 * *$ & $0.0390^{* *}$ & $0.0391 * *$ \\
\hline & $(2.149)$ & (2.185) & $(2.254)$ & $(2.328)$ \\
\hline \multirow[t]{2}{*}{ Centrality $\times$ Week 4} & $0.00140^{* *}$ & $0.00145 * *$ & $0.0299 * *$ & $0.0315^{* *}$ \\
\hline & $(2.158)$ & $(2.233)$ & $(1.996)$ & $(2.102)$ \\
\hline \multirow[t]{2}{*}{ Centrality } & -0.00137 & -0.00102 & -0.0197 & -0.0114 \\
\hline & $(-1.576)$ & $(-1.018)$ & $(-1.580)$ & $(-0.971)$ \\
\hline \multirow[t]{2}{*}{ Competition } & $-0.00247 *$ & $-0.00217^{*}$ & $-0.0491 *$ & -0.0437 \\
\hline & $(-1.939)$ & $(-1.750)$ & $(-1.719)$ & $(-1.575)$ \\
\hline \multirow[t]{2}{*}{ Week 1} & -0.00226 & -0.00205 & -0.0460 & -0.0416 \\
\hline & $(-1.560)$ & $(-1.447)$ & $(-1.437)$ & $(-1.328)$ \\
\hline \multirow[t]{2}{*}{ Week 2} & $-0.00391 * * *$ & $-0.00360 * *$ & $-0.0809 * *$ & $-0.0758^{* *}$ \\
\hline & $(-2.591)$ & $(-2.455)$ & $(-2.434)$ & $(-2.351)$ \\
\hline \multirow[t]{2}{*}{ Week 3} & $-0.00359 * *$ & $-0.00369 * *$ & $-0.0887^{* *}$ & $-0.0920 * * *$ \\
\hline & $(-2.289)$ & $(-2.407)$ & $(-2.496)$ & $(-2.671)$ \\
\hline \multirow[t]{2}{*}{ Week 4} & $-0.00307^{*}$ & $-0.00318^{*}$ & -0.0641 & $-0.0687 *$ \\
\hline & $(-1.663)$ & $(-1.696)$ & $(-1.601)$ & $(-1.688)$ \\
\hline Controls & Yes & Yes & Yes & Yes \\
\hline Manager FE & Yes & No & Yes & No \\
\hline Manager-Time FE & No & Yes & No & Yes \\
\hline Stock-Time FE & Yes & Yes & Yes & Yes \\
\hline Observations & $22,271,277$ & $22,251,239$ & $22,214,272$ & $22,194,225$ \\
\hline R-squared & 0.071 & 0.084 & 0.069 & 0.082 \\
\hline
\end{tabular}


Panel C: Other Brokers

(1)

(2)

(3)

(4)

Dummy $=1$ if follower trades in the same direction as the informed trade

Log of dollar imbalances from followers

\begin{tabular}{lcccc} 
Competition & $0.00778^{* * *}$ & $0.00765^{* * *}$ & $0.195^{* * *}$ & $0.192^{* * *}$ \\
Week 1 & $(3.982)$ & $(3.939)$ & $(4.074)$ & $(4.034)$ \\
& 0.000467 & 0.000511 & 0.0152 & $0.0160^{*}$ \\
Week 2 & $(1.137)$ & $(1.248)$ & $(1.558)$ & $(1.652)$ \\
& -0.000400 & -0.000398 & -0.00792 & -0.00786 \\
Week 3 & $(-0.538)$ & $(-0.534)$ & $(-0.460)$ & $(-0.456)$ \\
& -0.000396 & -0.000395 & -0.00859 & -0.00854 \\
Week 4 & $(-0.453)$ & $(-0.451)$ & $(-0.430)$ & $(-0.427)$ \\
& -0.000706 & -0.000695 & -0.0162 & -0.0159 \\
& $(-0.799)$ & $(-0.786)$ & $(-0.818)$ & $(-0.806)$ \\
Controls & & & & \\
Manager FE & Yes & Yes & Yes & Yes \\
Manager-Time FE & Yes & No & Yes & No \\
Stock-Time FE & No & Yes & No & Yes \\
& Yes & Yes & Yes & Yes \\
Observations & & & & \\
R-squared & $297,913,061$ & $297,909,931$ & $297,154,864$ & $297,151,734$ \\
& 0.017 & 0.020 & 0.016 & 0.019 \\
\hline
\end{tabular}


Panel D: Other Brokers - Central vs Peripheral

\begin{tabular}{|c|c|c|c|c|}
\hline & \multicolumn{2}{|c|}{$\begin{array}{l}\text { Dummy }=1 \text { if follower trades in the } \\
\text { same direction as the informed trade }\end{array}$} & \multicolumn{2}{|c|}{$\begin{array}{c}\text { Log of dollar imbalances from } \\
\text { followers }\end{array}$} \\
\hline Centrality $\times$ Competition & $\begin{array}{c}0.00149 \\
(1.380)\end{array}$ & $\begin{array}{c}0.00144 \\
(1.339)\end{array}$ & $\begin{array}{l}0.0369 \\
(1.422)\end{array}$ & $\begin{array}{l}0.0354 \\
(1.377)\end{array}$ \\
\hline Centrality $\times$ Week 1 & $\begin{array}{c}-0.000662^{* * * *} \\
(-3.383)\end{array}$ & $\begin{array}{c}-0.000650^{* * * *} \\
(-3.353)\end{array}$ & $\begin{array}{c}-0.0169 * * * \\
(-3.598)\end{array}$ & $\begin{array}{c}-0.0166 * * * \\
(-3.570)\end{array}$ \\
\hline Centrality $\times$ Week 2 & $\begin{array}{c}-0.000271 \\
(-1.367)\end{array}$ & $\begin{array}{c}-0.000264 \\
(-1.330)\end{array}$ & $\begin{array}{c}-0.00649 \\
(-1.396)\end{array}$ & $\begin{array}{c}-0.00633 \\
(-1.362)\end{array}$ \\
\hline Centrality $\times$ Week 3 & $\begin{array}{c}-0.000234 \\
(-1.300)\end{array}$ & $\begin{array}{c}-0.000230 \\
(-1.283)\end{array}$ & $\begin{array}{c}-0.00603 \\
(-1.423)\end{array}$ & $\begin{array}{c}-0.00598 \\
(-1.411)\end{array}$ \\
\hline Centrality $\times$ Week 4 & $\begin{array}{c}-6.93 e-05 \\
(-0.328)\end{array}$ & $\begin{array}{l}-6.98 \mathrm{e}-05 \\
(-0.330)\end{array}$ & $\begin{array}{c}-0.00160 \\
(-0.325)\end{array}$ & $\begin{array}{l}-0.00163 \\
(-0.331)\end{array}$ \\
\hline Centrality & $\begin{array}{c}0.000137 \\
(0.620)\end{array}$ & $\begin{array}{c}0.000153 \\
(0.683)\end{array}$ & $\begin{array}{c}0.00516 \\
(0.979)\end{array}$ & $\begin{array}{c}0.00552 \\
(1.036)\end{array}$ \\
\hline Competition & $\begin{array}{c}0.00482^{* *} \\
(2.519)\end{array}$ & $\begin{array}{c}0.00480^{* *} \\
(2.518)\end{array}$ & $\begin{array}{c}0.122^{* * *} \\
(2.642)\end{array}$ & $\begin{array}{c}0.122 * * * \\
(2.640)\end{array}$ \\
\hline Week 1 & $\begin{array}{l}0.00167^{* * *} \\
(3.956)\end{array}$ & $\begin{array}{c}0.00169 * * * \\
(4.037)\end{array}$ & $\begin{array}{c}0.0459^{* * *} \\
(4.501)\end{array}$ & $\begin{array}{c}0.0462^{* * *} \\
(4.568)\end{array}$ \\
\hline Week 2 & $\begin{array}{c}9.54 \mathrm{e}-05 \\
(0.114)\end{array}$ & $\begin{array}{c}8.50 \mathrm{e}-05 \\
(0.101)\end{array}$ & $\begin{array}{l}0.00394 \\
(0.208)\end{array}$ & $\begin{array}{l}0.00370 \\
(0.195)\end{array}$ \\
\hline Week 3 & $\begin{array}{l}3.11 \mathrm{e}-05 \\
(0.0341)\end{array}$ & $\begin{array}{c}2.64 \mathrm{e}-05 \\
(0.0289)\end{array}$ & $\begin{array}{c}0.00244 \\
(0.119)\end{array}$ & $\begin{array}{c}0.00238 \\
(0.117)\end{array}$ \\
\hline Week 4 & $\begin{array}{c}-0.000579 \\
(-0.601)\end{array}$ & $\begin{array}{c}-0.000567 \\
(-0.588)\end{array}$ & $\begin{array}{l}-0.0132 \\
(-0.627)\end{array}$ & $\begin{array}{l}-0.0129 \\
(-0.612)\end{array}$ \\
\hline Controls & Yes & Yes & Yes & Yes \\
\hline Manager FE & Yes & No & Yes & No \\
\hline Manager-Time FE & No & Yes & No & Yes \\
\hline Stock-Time FE & Yes & Yes & Yes & Yes \\
\hline $\begin{array}{l}\text { Observations } \\
\text { R-squared }\end{array}$ & $\begin{array}{c}297,913,061 \\
0.017\end{array}$ & $\begin{array}{c}297,909,931 \\
0.020\end{array}$ & $\begin{array}{c}297,154,864 \\
0.016\end{array}$ & $\begin{array}{c}297,151,734 \\
0.019\end{array}$ \\
\hline
\end{tabular}




\section{Table 9. Affiliation}

This table relates the trading behavior of followers after a large trade. This time we split the sample between large trades for which the originator and the broker intermediating the trade are affiliated, and large trades for which this is not true. We further split each of these two sub-sample in two parts: large trades intermediated by central brokers (centrality above the median) and large trades intermediated by peripheral brokers (centrality below the median). The structure of the tests is the same as in Panel A of Table 5. In Panel A the dependent variable is a dummy that takes value one if the follower trades in the same direction as the originator and zero otherwise; in Panel B it is the log of the net dollar volume of the followers. T-stats based on robust standard errors, double-clustered at both the month and the manager level, are reported in parentheses. Asterisks denote significance levels $(* * *=1 \%, * *=5 \%, *=10 \%)$.

Panel A

Dependent Variable: Dummy equal to one if follower trades in the same direction as the informed trade

\begin{tabular}{|c|c|c|c|c|c|c|c|c|}
\hline & $(1)$ & (2) & (3) & (4) & (5) & (6) & (7) & $(8)$ \\
\hline & \multicolumn{4}{|c|}{ Originator is AFFILIATED with the Broker } & \multicolumn{4}{|c|}{ Originator is NOT AFFILIATED with the Broker } \\
\hline & \multicolumn{2}{|c|}{ CENTRAL Brokers } & \multicolumn{2}{|c|}{ PERIPHERAL Brokers } & \multicolumn{2}{|c|}{ CENTRAL Brokers } & \multicolumn{2}{|c|}{ PERIPHERAL Brokers } \\
\hline Competition & $\begin{array}{l}0.0187 \\
(0.241)\end{array}$ & $\begin{array}{l}0.0176 \\
(0.381)\end{array}$ & $\begin{array}{c}0.215^{* * *} \\
(21.67)\end{array}$ & $\begin{array}{c}0.214 * * * \\
(21.06)\end{array}$ & $\begin{array}{c}0.0748^{* * *} \\
(5.096)\end{array}$ & $\begin{array}{c}0.0719^{* * *} \\
(4.887)\end{array}$ & $\begin{array}{c}0.0390^{* * *} \\
(4.456)\end{array}$ & $\begin{array}{c}0.0352^{* * *} \\
(4.101)\end{array}$ \\
\hline Week 1 & $\begin{array}{l}0.0354 \\
(1.114)\end{array}$ & $\begin{array}{l}0.0200 \\
(0.685)\end{array}$ & $\begin{array}{c}0.102^{* * *} \\
(21.32)\end{array}$ & $\begin{array}{c}0.101 * * * \\
(22.18)\end{array}$ & $\begin{array}{c}0.00318^{* * *} \\
(3.646)\end{array}$ & $\begin{array}{c}0.00320^{* * * *} \\
(3.589)\end{array}$ & $\begin{array}{c}0.000852 \\
(0.837)\end{array}$ & $\begin{array}{c}0.00105 \\
(1.022)\end{array}$ \\
\hline Week 2 & $\begin{array}{l}0.0511 \\
(1.346)\end{array}$ & $\begin{array}{l}0.0292 \\
(0.903)\end{array}$ & $\begin{array}{c}0.0340^{* *} \\
(2.641)\end{array}$ & $\begin{array}{c}0.0326^{* *} \\
(2.580)\end{array}$ & $\begin{array}{c}-0.00198^{* *} \\
(-2.001)\end{array}$ & $\begin{array}{c}-0.00190^{* *} \\
(-1.970)\end{array}$ & $\begin{array}{c}-0.000153 \\
(-0.129)\end{array}$ & $\begin{array}{c}0.000180 \\
(0.154)\end{array}$ \\
\hline Week 3 & $\begin{array}{l}0.0296 \\
(0.661)\end{array}$ & $\begin{array}{l}0.0120 \\
(0.297)\end{array}$ & $\begin{array}{c}-0.0396^{* * *} \\
(-7.569)\end{array}$ & $\begin{array}{c}-0.0400^{* * *} \\
(-8.386)\end{array}$ & $\begin{array}{c}-0.00253^{*} \\
(-1.957)\end{array}$ & $\begin{array}{c}-0.00259^{* *} \\
(-2.045)\end{array}$ & $\begin{array}{c}-0.000909 \\
(-0.787)\end{array}$ & $\begin{array}{c}-0.000477 \\
(-0.410)\end{array}$ \\
\hline Week 4 & $\begin{array}{l}0.0506 \\
(1.266)\end{array}$ & $\begin{array}{l}0.0181 \\
(0.514)\end{array}$ & $\begin{array}{c}-0.0234^{*} \\
(-1.891)\end{array}$ & $\begin{array}{c}-0.0238^{*} \\
(-1.889)\end{array}$ & $\begin{array}{c}-0.00375^{* *} \\
(-2.234)\end{array}$ & $\begin{array}{c}-0.00377 * * \\
(-2.302)\end{array}$ & $\begin{array}{c}-0.000655 \\
(-0.481)\end{array}$ & $\begin{array}{r}-0.000230 \\
(-0.172)\end{array}$ \\
\hline Controls & Yes & Yes & Yes & Yes & Yes & Yes & Yes & Yes \\
\hline Manager FE & Yes & No & Yes & No & Yes & No & Yes & No \\
\hline Manager-Time FE & No & Yes & No & Yes & No & Yes & No & Yes \\
\hline Stock-Time FE & Yes & Yes & Yes & Yes & Yes & Yes & Yes & Yes \\
\hline Observations & 2,264 & 2,058 & 4,568 & 4,373 & $13,454,833$ & $13,435,350$ & $7,439,591$ & $7,415,781$ \\
\hline R-squared & 0.755 & 0.816 & 0.549 & 0.570 & 0.097 & 0.113 & 0.128 & 0.153 \\
\hline
\end{tabular}


Panel B

Dependent Variable: Log of dollar imbalances from the follower

\begin{tabular}{|c|c|c|c|c|c|c|c|c|}
\hline & (1) & (2) & (3) & (4) & (5) & (6) & (7) & (8) \\
\hline & \multicolumn{4}{|c|}{ Originator is AFFILIATED with the Broker } & \multicolumn{4}{|c|}{ Originator is NOT AFFILIATED with the Broker } \\
\hline & \multicolumn{2}{|c|}{ CENTRAL Brokers } & \multicolumn{2}{|c|}{ PERIPHERAL Brokers } & \multicolumn{2}{|c|}{ CENTRAL Brokers } & \multicolumn{2}{|c|}{ PERIPHERAL Brokers } \\
\hline Competition & $\begin{array}{c}0.749 \\
(0.409)\end{array}$ & $\begin{array}{c}0.692 \\
(0.642)\end{array}$ & $\begin{array}{c}5.345^{* * *} \\
(20.27)\end{array}$ & $\begin{array}{c}5.329^{* * *} \\
(19.57)\end{array}$ & $\begin{array}{c}1.822^{* * *} \\
(5.040)\end{array}$ & $\begin{array}{c}1.760^{* * *} \\
(4.849)\end{array}$ & $\begin{array}{c}0.935^{* * *} \\
(4.262)\end{array}$ & $\begin{array}{c}0.851 * * * \\
(3.937)\end{array}$ \\
\hline Week 1 & $\begin{array}{c}0.807 \\
(1.031)\end{array}$ & $\begin{array}{c}0.357 \\
(0.492)\end{array}$ & $\begin{array}{c}2.502^{* * *} \\
(18.32)\end{array}$ & $\begin{array}{c}2.483^{* * *} \\
(21.65)\end{array}$ & $\begin{array}{c}0.0772^{* * *} \\
(3.615)\end{array}$ & $\begin{array}{c}0.0779 * * * \\
(3.577)\end{array}$ & $\begin{array}{l}0.0197 \\
(0.832)\end{array}$ & $\begin{array}{l}0.0230 \\
(0.968)\end{array}$ \\
\hline Week 2 & $\begin{array}{c}1.194 \\
(1.273)\end{array}$ & $\begin{array}{c}0.601 \\
(0.774)\end{array}$ & $\begin{array}{c}0.744^{* *} \\
(2.426)\end{array}$ & $\begin{array}{c}0.703^{* *} \\
(2.295)\end{array}$ & $\begin{array}{c}-0.0435^{*} \\
(-1.907)\end{array}$ & $\begin{array}{c}-0.0414^{*} \\
(-1.861)\end{array}$ & $\begin{array}{c}-0.00322 \\
(-0.125)\end{array}$ & $\begin{array}{c}0.00335 \\
(0.131)\end{array}$ \\
\hline Week 3 & $\begin{array}{c}0.850 \\
(0.760)\end{array}$ & $\begin{array}{l}0.332 \\
(0.324)\end{array}$ & $\begin{array}{c}-0.994 * * * \\
(-7.665)\end{array}$ & $\begin{array}{c}-1.013^{* * *} \\
(-10.34)\end{array}$ & $\begin{array}{c}-0.0664 * * \\
(-2.268)\end{array}$ & $\begin{array}{c}-0.0678^{* *} \\
(-2.351)\end{array}$ & $\begin{array}{l}-0.0140 \\
(-0.563)\end{array}$ & $\begin{array}{c}-0.00521 \\
(-0.209)\end{array}$ \\
\hline Week 4 & $\begin{array}{c}1.276 \\
(1.254)\end{array}$ & $\begin{array}{c}0.354 \\
(0.401)\end{array}$ & $\begin{array}{c}-0.644^{* *} \\
(-2.010)\end{array}$ & $\begin{array}{c}-0.663^{* *} \\
(-2.042)\end{array}$ & $\begin{array}{c}-0.0879 * * \\
(-2.240)\end{array}$ & $\begin{array}{c}-0.0891 * * \\
(-2.309)\end{array}$ & $\begin{array}{l}-0.0121 \\
(-0.425)\end{array}$ & $\begin{array}{c}-0.00386 \\
(-0.138)\end{array}$ \\
\hline Controls & Yes & Yes & Yes & Yes & Yes & Yes & Yes & Yes \\
\hline Manager FE & Yes & No & Yes & No & Yes & No & Yes & No \\
\hline Manager-Time FE & No & Yes & No & Yes & No & Yes & No & Yes \\
\hline Stock-Time FE & Yes & Yes & Yes & Yes & Yes & Yes & Yes & Yes \\
\hline Observations & 2,264 & 2,058 & 4,566 & 4,370 & $13,418,173$ & $13,398,696$ & $7,421,039$ & $7,397,217$ \\
\hline R-squared & 0.751 & 0.816 & 0.554 & 0.572 & 0.093 & 0.111 & 0.126 & 0.154 \\
\hline
\end{tabular}




\section{Table 10. Activists}

In this table we test the trading behavior of Ancerno traders before the filing of a 13D schedule from an activist investor. The dependent variable is either a dummy identifying BUY trades (Panel A, Panel C and Panel E) or the log of net dollar volumes from the manager, multiplied by 1 in case of a net buy volume, or by -1 in case of a net sell volume (Panel B, Panel D and Panel F). In Panel $\mathrm{B}$ and Panel $\mathrm{C}$ we restrict the sample to $13 \mathrm{D}$ filings in which the prime broker of the activist investor is a central broker; in Panel E and Panel F we restrict the sample to 13D filings in which the prime broker of the activist investor is a peripheral broker; Panel A and Panel B consider all brokers. Brokers are split into central and peripheral by comparing their centrality measure with the median of centrality distribution in a given month. In all panels, we consider a time range of 60 trading days before and after the filing. The time dummies indicate the day on which the 13D filing happens (Filing Day), the 10 trading days before the filing (Just Before) and the period that goes from 60 to 10 trading days before the filing (Before). The imbalances are computed at the day level and then averaged over the four time periods (Before, Just Before, Filing Date and after the filing date), obtaining in this way a database at the 13D filing / Ancerno manager / time period level; a 13D filing is identified by an activist, the stock involved in the filing and the filing date. We interact the time dummies by a dummy (Strong Relation) that identifies, among all the managers who are trading the stock, the ones who have a stronger relationship with the activist's prime broker. We use four different proxies for the strength of the manager-broker relationship. The first three proxies identify the top quarter of the distributions of the three following variables. First, we consider the trading volume that the manager originated for the broker in the past. More specifically, we divide the volume originated from the manager by the total volume intermediated by the broker, thus obtaining the percentage volume. Then, for each broker, we sort the managers in increasing order of volume and compute the measure as the cumulative percentage volume generated by each manager and all the other managers who traded less than she did with the broker. The second measure is computed in a very similar fashion, but the dollar volume is replaced by the dollar trading commissions generated by the manager. The third measure is obtained as the average number of days that passes from two consecutive trades of each manager with the same broker, multiplied by minus one (so that it is positively related with the trading frequency). We estimate each proxy over the six months preceding the month in which the trading takes place. The last proxy is a dummy that identifies an affiliation relationship between a manager and the activist's prime broker. A positive value for the coefficient of the interaction between the time dummy and the relationship dummy suggests that the prime broker's best client bought more/more frequently than the other managers in that period, compared to what they did after the 13D filing. T-stats based on robust standard errors, double-clustered at both the time and the manager level, are reported in parentheses. Asterisks denote significance levels $(* * *=1 \%, * *=5 \%$, $*=10 \%)$. 
Panel A: All Brokers

Dependent Variable is a Dummy identifying BUY trades

\begin{tabular}{|c|c|c|c|c|c|c|c|c|c|c|c|c|}
\hline \multirow{3}{*}{$\begin{array}{l}\text { Strength of relationship proxy: } \\
\text { Strong Relation }\end{array}$} & (1) & (2) & (3) & (4) & (5) & (6) & (7) & (8) & (9) & $(10)$ & $(11)$ & $(12)$ \\
\hline & \multicolumn{3}{|c|}{$\begin{array}{c}\text { Ranking of Manager-Broker } \\
\text { Volume }\end{array}$} & \multicolumn{3}{|c|}{ Ranking of Revenue Share } & \multicolumn{3}{|c|}{$\begin{array}{c}\text { Frequency of Manager-Broker } \\
\text { Interaction }\end{array}$} & \multicolumn{3}{|c|}{ Broker - Manager Affiliation } \\
\hline & $\begin{array}{c}-0.00648 \\
(-0.694)\end{array}$ & $\begin{array}{l}0.00104 \\
(0.0216)\end{array}$ & $\begin{array}{c}-0.00508 \\
(-0.524)\end{array}$ & $\begin{array}{c}-0.00462 \\
(-0.437)\end{array}$ & $\begin{array}{l}0.00561 \\
(0.117)\end{array}$ & $\begin{array}{c}-0.00260 \\
(-0.241)\end{array}$ & $\begin{array}{r}-0.000710 \\
(-0.0644)\end{array}$ & $\begin{array}{l}-0.000444 \\
(-0.0108)\end{array}$ & $\begin{array}{c}0.000523 \\
(0.0456)\end{array}$ & $\begin{array}{c}-0.0318^{* * *} \\
(-3.181)\end{array}$ & $\begin{array}{c}-0.0616^{* * *} \\
(-4.013)\end{array}$ & $\begin{array}{c}-0.0339 * * * \\
(-3.479)\end{array}$ \\
\hline Strong Relation $\times$ Before & $\begin{array}{l}0.00240 \\
(0.262)\end{array}$ & $\begin{array}{c}0.000855 \\
(0.0872)\end{array}$ & $\begin{array}{c}0.00108 \\
(0.118)\end{array}$ & $\begin{array}{l}0.00152 \\
(0.168)\end{array}$ & $\begin{array}{l}-0.000167 \\
(-0.0171)\end{array}$ & $\begin{array}{l}-3.91 \mathrm{e}-05 \\
(-0.00432)\end{array}$ & $\begin{array}{l}-0.0106 \\
(-0.909)\end{array}$ & $\begin{array}{l}-0.0111 \\
(-0.883)\end{array}$ & $\begin{array}{l}-0.0114 \\
(-0.967)\end{array}$ & $\begin{array}{c}0.0703^{* *} \\
(2.176)\end{array}$ & $\begin{array}{c}0.0603^{* *} \\
(1.971)\end{array}$ & $\begin{array}{c}0.0670^{* *} \\
(2.082)\end{array}$ \\
\hline Strong Relation $\times$ Just Before & $\begin{array}{c}0.0363^{* * *} \\
(3.144)\end{array}$ & $\begin{array}{c}0.0546^{* * *} \\
(3.588)\end{array}$ & $\begin{array}{c}0.0363^{* * *} \\
(3.095)\end{array}$ & $\begin{array}{c}0.0308^{* * *} \\
(2.604)\end{array}$ & $\begin{array}{l}0.0516^{* * *} \\
(3.207)\end{array}$ & $\begin{array}{c}0.0306^{* *} \\
(2.535)\end{array}$ & $\begin{array}{c}0.0262^{* *} \\
(2.201)\end{array}$ & $\begin{array}{c}0.0437^{* * *} \\
(2.884)\end{array}$ & $\begin{array}{c}0.0258^{* *} \\
(2.184)\end{array}$ & $\begin{array}{c}0.0560^{* * *} \\
(8.773)\end{array}$ & $\begin{array}{c}0.0452^{* * *} \\
(3.523)\end{array}$ & $\begin{array}{l}0.0548^{* * *} \\
(7.247)\end{array}$ \\
\hline Strong Relation $\times$ Filing Day & $\begin{array}{r}-0.000966 \\
(-0.0373)\end{array}$ & $\begin{array}{l}0.0715^{*} \\
(1.742)\end{array}$ & $\begin{array}{c}0.000812 \\
(0.0310)\end{array}$ & $\begin{array}{c}-0.00297 \\
(-0.112)\end{array}$ & $\begin{array}{l}0.0711^{*} \\
(1.707)\end{array}$ & $\begin{array}{l}-0.00167 \\
(-0.0629)\end{array}$ & $\begin{array}{l}-0.0111 \\
(-0.482)\end{array}$ & $\begin{array}{l}0.0525 \\
(1.524)\end{array}$ & $\begin{array}{c}-0.00934 \\
(-0.403)\end{array}$ & $\begin{array}{c}0.0355^{* *} \\
(2.334)\end{array}$ & $\begin{array}{c}0.00389 \\
(0.101)\end{array}$ & $\begin{array}{c}0.0385^{* *} \\
(2.468)\end{array}$ \\
\hline Before & $\begin{array}{c}-0.00962 \\
(-1.072)\end{array}$ & $\begin{array}{l}-0.0133 \\
(-1.444)\end{array}$ & $\begin{array}{c}-0.00613 \\
(-0.674)\end{array}$ & $\begin{array}{c}-0.00944 \\
(-1.073)\end{array}$ & $\begin{array}{l}-0.0131 \\
(-1.443)\end{array}$ & $\begin{array}{c}-0.00589 \\
(-0.662)\end{array}$ & $\begin{array}{c}-0.00683 \\
(-0.754)\end{array}$ & $\begin{array}{l}-0.0108 \\
(-1.163)\end{array}$ & $\begin{array}{c}-0.00345 \\
(-0.376)\end{array}$ & $\begin{array}{c}-0.00954 \\
(-1.155)\end{array}$ & $\begin{array}{l}-0.0135 \\
(-1.578)\end{array}$ & $\begin{array}{c}-0.00630 \\
(-0.756)\end{array}$ \\
\hline Just Before & $\begin{array}{c}-0.0211^{* *} \\
(-2.128)\end{array}$ & $\begin{array}{c}-0.0210^{*} \\
(-1.950)\end{array}$ & $\begin{array}{c}-0.0200^{* *} \\
(-2.051)\end{array}$ & $\begin{array}{c}-0.0196 * * \\
(-1.986)\end{array}$ & $\begin{array}{c}-0.0202^{*} \\
(-1.898)\end{array}$ & $\begin{array}{c}-0.0184^{*} \\
(-1.901)\end{array}$ & $\begin{array}{c}-0.0187^{*} \\
(-1.847)\end{array}$ & $\begin{array}{l}-0.0177 \\
(-1.579)\end{array}$ & $\begin{array}{c}-0.0175^{*} \\
(-1.758)\end{array}$ & $\begin{array}{l}-0.0118 \\
(-1.279)\end{array}$ & $\begin{array}{c}-0.00575 \\
(-0.423)\end{array}$ & $\begin{array}{l}-0.0107 \\
(-1.174)\end{array}$ \\
\hline Filing Date & $\begin{array}{c}0.00657 \\
(0.378)\end{array}$ & $\begin{array}{l}0.0119 \\
(0.598)\end{array}$ & $\begin{array}{c}0.00694 \\
(0.401)\end{array}$ & $\begin{array}{c}0.00703 \\
(0.406)\end{array}$ & $\begin{array}{l}0.0113 \\
(0.574)\end{array}$ & $\begin{array}{c}0.00756 \\
(0.439)\end{array}$ & $\begin{array}{c}0.00913 \\
(0.538)\end{array}$ & $\begin{array}{l}0.0201 \\
(0.905)\end{array}$ & $\begin{array}{c}0.00953 \\
(0.561)\end{array}$ & $\begin{array}{c}0.00439 \\
(0.307)\end{array}$ & $\begin{array}{l}0.0406 \\
(1.131)\end{array}$ & $\begin{array}{c}0.00552 \\
(0.378)\end{array}$ \\
\hline Manager FE & Yes & No & Yes & Yes & No & Yes & Yes & No & Yes & Yes & No & Yes \\
\hline Stock FE & Yes & Yes & No & Yes & Yes & No & Yes & Yes & No & Yes & Yes & No \\
\hline Stock - Time FE & No & No & Yes & No & No & Yes & No & No & Yes & No & No & Yes \\
\hline Time FE & No & Yes & No & No & Yes & No & No & Yes & No & No & Yes & No \\
\hline Observations & 96,819 & 96,857 & 96,810 & 96,819 & 96,857 & 96,810 & 96,819 & 96,857 & 96,810 & 96,819 & 96,857 & 96,810 \\
\hline R-squared & 0.124 & 0.064 & 0.13 & 0.124 & 0.064 & 0.13 & 0.124 & 0.064 & 0.130 & 0.124 & 0.063 & 0.130 \\
\hline
\end{tabular}




\section{Panel B: All Brokers}

Dependent Variable is the Log of Dollar Imbalances

\begin{tabular}{|c|c|c|c|c|c|c|c|c|c|c|c|c|}
\hline \multirow[b]{2}{*}{ Strength of relationship proxy: } & (1) & (2) & (3) & (4) & (5) & (6) & (7) & (8) & (9) & $(10)$ & $(11)$ & $(12)$ \\
\hline & \multicolumn{3}{|c|}{$\begin{array}{c}\text { Ranking of Manager-Broker } \\
\text { Volume }\end{array}$} & \multicolumn{3}{|c|}{ Ranking of Revenue Share } & \multicolumn{3}{|c|}{$\begin{array}{c}\text { Frequency of Manager-Broker } \\
\text { Interaction }\end{array}$} & \multicolumn{3}{|c|}{ Broker - Manager Affiliation } \\
\hline Strong Relation & $\begin{array}{c}-0.202 \\
(-1.017)\end{array}$ & $\begin{array}{l}-0.0351 \\
(-0.0356)\end{array}$ & $\begin{array}{l}-0.167 \\
(-0.804)\end{array}$ & $\begin{array}{l}-0.189 \\
(-0.828)\end{array}$ & $\begin{array}{c}0.0312 \\
(0.0309)\end{array}$ & $\begin{array}{c}-0.142 \\
(-0.610)\end{array}$ & $\begin{array}{l}-0.148 \\
(-0.660)\end{array}$ & $\begin{array}{l}-0.0634 \\
(-0.0749)\end{array}$ & $\begin{array}{l}-0.118 \\
(-0.508)\end{array}$ & $\begin{array}{l}-0.615 \\
(-1.647)\end{array}$ & $\begin{array}{c}-1.049 * * * \\
(-2.981)\end{array}$ & $\begin{array}{l}-0.660^{*} \\
(-1.840)\end{array}$ \\
\hline Strong Relation $\times$ Before & $\begin{array}{l}0.0356 \\
(0.176)\end{array}$ & $\begin{array}{c}0.0135 \\
(0.0595)\end{array}$ & $\begin{array}{c}0.0126 \\
(0.0623)\end{array}$ & $\begin{array}{l}0.0330 \\
(0.168)\end{array}$ & $\begin{array}{l}-0.00306 \\
(-0.0136)\end{array}$ & $\begin{array}{l}0.00362 \\
(0.0180)\end{array}$ & $\begin{array}{l}-0.216 \\
(-0.858)\end{array}$ & $\begin{array}{l}-0.228 \\
(-0.812)\end{array}$ & $\begin{array}{l}-0.226 \\
(-0.889)\end{array}$ & $\begin{array}{l}1.202^{* *} \\
(1.976)\end{array}$ & $\begin{array}{l}1.031 * \\
(1.679)\end{array}$ & $\begin{array}{l}1.143^{*} \\
(1.834)\end{array}$ \\
\hline Strong Relation $\times$ Just Before & $\begin{array}{l}0.691 * * \\
(2.500)\end{array}$ & $\begin{array}{c}1.098^{* * *} \\
(3.342)\end{array}$ & $\begin{array}{l}0.682^{* *} \\
(2.445)\end{array}$ & $\begin{array}{l}0.524^{*} \\
(1.919)\end{array}$ & $\begin{array}{c}0.982^{* * *} \\
(2.808)\end{array}$ & $\begin{array}{l}0.508^{*} \\
(1.838)\end{array}$ & $\begin{array}{l}0.563^{* *} \\
(2.083)\end{array}$ & $\begin{array}{c}0.936^{* * *} \\
(3.022)\end{array}$ & $\begin{array}{r}0.550^{* *} \\
(2.066)\end{array}$ & $\begin{array}{c}1.231 * * * \\
(9.927)\end{array}$ & $\begin{array}{c}1.091 * * * \\
(3.858)\end{array}$ & $\begin{array}{l}1.205^{* * *} \\
(7.662)\end{array}$ \\
\hline Strong Relation $\times$ Filing Day & $\begin{array}{l}0.0865 \\
(0.146)\end{array}$ & $\begin{array}{l}1.609 * \\
(1.797)\end{array}$ & $\begin{array}{c}0.106 \\
(0.179)\end{array}$ & $\begin{array}{l}0.0639 \\
(0.108)\end{array}$ & $\begin{array}{l}1.648^{*} \\
(1.831)\end{array}$ & $\begin{array}{l}0.0749 \\
(0.127)\end{array}$ & $\begin{array}{c}0.0170 \\
(0.0323)\end{array}$ & $\begin{array}{l}1.345^{*} \\
(1.834)\end{array}$ & $\begin{array}{c}0.0451 \\
(0.0860)\end{array}$ & $\begin{array}{l}0.678^{* *} \\
(2.077)\end{array}$ & $\begin{array}{c}0.0675 \\
(0.0844)\end{array}$ & $\begin{array}{c}0.709 * * \\
(2.029)\end{array}$ \\
\hline Before & $\begin{array}{c}-0.135 \\
(-0.645)\end{array}$ & $\begin{array}{c}-0.228 \\
(-1.060)\end{array}$ & $\begin{array}{l}-0.0561 \\
(-0.266)\end{array}$ & $\begin{array}{l}-0.134 \\
(-0.659)\end{array}$ & $\begin{array}{l}-0.224 \\
(-1.066)\end{array}$ & $\begin{array}{l}-0.0541 \\
(-0.263)\end{array}$ & $\begin{array}{l}-0.0810 \\
(-0.385)\end{array}$ & $\begin{array}{c}-0.177 \\
(-0.819)\end{array}$ & $\begin{array}{l}-0.00494 \\
(-0.0232)\end{array}$ & $\begin{array}{c}-0.135 \\
(-0.686)\end{array}$ & $\begin{array}{c}-0.233 \\
(-1.129)\end{array}$ & $\begin{array}{l}-0.0604 \\
(-0.303)\end{array}$ \\
\hline Just Before & $\begin{array}{l}-0.504^{* *} \\
(-2.295)\end{array}$ & $\begin{array}{l}-0.515^{* *} \\
(-2.202)\end{array}$ & $\begin{array}{c}-0.4777^{* *} \\
(-2.227)\end{array}$ & $\begin{array}{c}-0.458^{* *} \\
(-2.100)\end{array}$ & $\begin{array}{c}-0.483^{* *} \\
(-2.092)\end{array}$ & $\begin{array}{l}-0.430^{* *} \\
(-2.018)\end{array}$ & $\begin{array}{c}-0.476^{* *} \\
(-2.111)\end{array}$ & $\begin{array}{l}-0.466^{*} \\
(-1.922)\end{array}$ & $\begin{array}{c}-0.447 * * \\
(-2.037)\end{array}$ & $\begin{array}{c}-0.331 \\
(-1.644)\end{array}$ & $\begin{array}{c}-0.218 \\
(-0.779)\end{array}$ & $\begin{array}{l}-0.306 \\
(-1.557)\end{array}$ \\
\hline Filing Date & $\begin{array}{c}0.0114 \\
(0.0271)\end{array}$ & $\begin{array}{c}0.147 \\
(0.312)\end{array}$ & $\begin{array}{c}0.0181 \\
(0.0436)\end{array}$ & $\begin{array}{c}0.0133 \\
(0.0325)\end{array}$ & $\begin{array}{c}0.123 \\
(0.267)\end{array}$ & $\begin{array}{c}0.0226 \\
(0.0556)\end{array}$ & $\begin{array}{c}0.0174 \\
(0.0428)\end{array}$ & $\begin{array}{c}0.269 \\
(0.530)\end{array}$ & $\begin{array}{c}0.0220 \\
(0.0543)\end{array}$ & $\begin{array}{l}0.00755 \\
(0.0208)\end{array}$ & $\begin{array}{c}0.781 \\
(0.992)\end{array}$ & $\begin{array}{c}0.0242 \\
(0.0664)\end{array}$ \\
\hline Manager FE & Yes & No & Yes & Yes & No & Yes & Yes & No & Yes & Yes & No & Yes \\
\hline Stock FE & Yes & Yes & No & Yes & Yes & No & Yes & Yes & No & Yes & Yes & No \\
\hline Stock - Time FE & No & No & Yes & No & No & Yes & No & No & Yes & No & No & Yes \\
\hline Time FE & No & Yes & No & No & Yes & No & No & Yes & No & No & Yes & No \\
\hline Observations & 94,874 & 94,915 & 94,865 & 94,874 & 94,915 & 94,865 & 94,874 & 94,915 & 94,865 & 94,874 & 94,915 & 94,865 \\
\hline R-squared & 0.115 & 0.060 & 0.122 & 0.115 & 0.060 & 0.122 & 0.116 & 0.060 & 0.122 & 0.115 & 0.059 & 0.122 \\
\hline
\end{tabular}


Panel C: Central Brokers

Dependent Variable is a Dummy identifying BUY trades

\begin{tabular}{|c|c|c|c|c|c|c|c|c|c|c|c|c|}
\hline & (1) & (2) & (3) & (4) & (5) & (6) & $(7)$ & (8) & (9) & (10) & (11) & (12) \\
\hline Strength of relationship proxy: & \multicolumn{3}{|c|}{$\begin{array}{c}\text { Ranking of Manager-Broker } \\
\text { Volume }\end{array}$} & \multicolumn{3}{|c|}{ Ranking of Revenue Share } & \multicolumn{3}{|c|}{$\begin{array}{c}\text { Frequency of Manager-Broker } \\
\text { Interaction }\end{array}$} & \multicolumn{3}{|c|}{ Broker - Manager Affiliation } \\
\hline Strong Relation & $\begin{array}{l}-0.0131 \\
(-1.097)\end{array}$ & $\begin{array}{c}-0.000799 \\
(-0.0155)\end{array}$ & $\begin{array}{l}-0.0105 \\
(-0.868)\end{array}$ & $\begin{array}{l}-0.00393 \\
(-0.292)\end{array}$ & $\begin{array}{c}0.00824 \\
(0.163)\end{array}$ & $\begin{array}{l}-0.00116 \\
(-0.0863)\end{array}$ & $\begin{array}{l}-0.00619 \\
(-0.454)\end{array}$ & $\begin{array}{l}0.00114 \\
(0.0258)\end{array}$ & $\begin{array}{c}-0.00429 \\
(-0.315)\end{array}$ & $\begin{array}{c}-0.0575^{* * *} \\
(-4.627)\end{array}$ & $\begin{array}{c}-0.0766^{* * *} \\
(-4.526)\end{array}$ & $\begin{array}{c}-0.0595 * * * \\
(-5.574)\end{array}$ \\
\hline Strong Relation $\times$ Before & $\begin{array}{c}0.00416 \\
(0.347)\end{array}$ & $\begin{array}{c}0.00291 \\
(0.227)\end{array}$ & $\begin{array}{c}0.00268 \\
(0.226)\end{array}$ & $\begin{array}{l}-0.000477 \\
(-0.0449)\end{array}$ & $\begin{array}{l}-0.00144 \\
(-0.120)\end{array}$ & $\begin{array}{c}-0.00183 \\
(-0.170)\end{array}$ & $\begin{array}{l}-0.0133 \\
(-0.988)\end{array}$ & $\begin{array}{l}-0.0137 \\
(-0.923)\end{array}$ & $\begin{array}{l}-0.0141 \\
(-1.039)\end{array}$ & $\begin{array}{c}0.0945^{* * *} \\
(3.678)\end{array}$ & $\begin{array}{c}0.0898^{* * *} \\
(3.643)\end{array}$ & $\begin{array}{c}0.0925^{* * *} \\
(3.632)\end{array}$ \\
\hline Strong Relation $\times$ Just Before & $\begin{array}{c}0.0439 * * * \\
(2.892)\end{array}$ & $\begin{array}{c}0.0645^{* * *} \\
(3.324)\end{array}$ & $\begin{array}{c}0.0432 * * * \\
(2.825)\end{array}$ & $\begin{array}{c}0.0339 * * \\
(2.313)\end{array}$ & $\begin{array}{c}0.0576^{* * *} \\
(3.090)\end{array}$ & $\begin{array}{c}0.0334 * * \\
(2.251)\end{array}$ & $\begin{array}{c}0.0312^{* *} \\
(2.151)\end{array}$ & $\begin{array}{l}0.0503 * * * \\
(2.712)\end{array}$ & $\begin{array}{c}0.0301 * * \\
(2.078)\end{array}$ & $\begin{array}{c}0.0563^{* * *} \\
(4.220)\end{array}$ & $\begin{array}{c}0.0514 * * * \\
(2.948)\end{array}$ & $\begin{array}{c}0.0585^{* * *} \\
(4.067)\end{array}$ \\
\hline Strong Relation $\times$ Filing Day & $\begin{array}{c}0.00392 \\
(0.160)\end{array}$ & $\begin{array}{c}0.0770^{*} \\
(1.898)\end{array}$ & $\begin{array}{c}0.00454 \\
(0.185)\end{array}$ & $\begin{array}{l}-0.00783 \\
(-0.294)\end{array}$ & $\begin{array}{l}0.0678 \\
(1.627)\end{array}$ & $\begin{array}{c}-0.00708 \\
(-0.265)\end{array}$ & $\begin{array}{l}-0.00151 \\
(-0.0679)\end{array}$ & $\begin{array}{c}0.0611^{*} \\
(1.864)\end{array}$ & $\begin{array}{c}-0.000382 \\
(-0.0172)\end{array}$ & $\begin{array}{c}0.0521 * * * \\
(2.981)\end{array}$ & $\begin{array}{l}0.0165 \\
(0.421)\end{array}$ & $\begin{array}{c}0.0530^{* * *} \\
(3.301)\end{array}$ \\
\hline Before & $\begin{array}{c}-0.00665 \\
(-0.694)\end{array}$ & $\begin{array}{l}-0.0106 \\
(-1.069)\end{array}$ & $\begin{array}{c}-0.00345 \\
(-0.354)\end{array}$ & $\begin{array}{c}-0.00569 \\
(-0.604)\end{array}$ & $\begin{array}{c}-0.00967 \\
(-0.993)\end{array}$ & $\begin{array}{c}-0.00251 \\
(-0.262)\end{array}$ & $\begin{array}{c}-0.00285 \\
(-0.298)\end{array}$ & $\begin{array}{c}-0.00709 \\
(-0.715)\end{array}$ & $\begin{array}{c}0.000193 \\
(0.0199)\end{array}$ & $\begin{array}{c}-0.00638 \\
(-0.703)\end{array}$ & $\begin{array}{l}-0.0107 \\
(-1.150)\end{array}$ & $\begin{array}{c}-0.00348 \\
(-0.375)\end{array}$ \\
\hline Just Before & $\begin{array}{c}-0.0183^{*} \\
(-1.677)\end{array}$ & $\begin{array}{c}-0.0203^{*} \\
(-1.768)\end{array}$ & $\begin{array}{l}-0.0170 \\
(-1.583)\end{array}$ & $\begin{array}{l}-0.0157 \\
(-1.456)\end{array}$ & $\begin{array}{l}-0.0187 \\
(-1.645)\end{array}$ & $\begin{array}{l}-0.0145 \\
(-1.364)\end{array}$ & $\begin{array}{l}-0.0153 \\
(-1.396)\end{array}$ & $\begin{array}{l}-0.0165 \\
(-1.415)\end{array}$ & $\begin{array}{l}-0.0140 \\
(-1.289)\end{array}$ & $\begin{array}{c}-0.00694 \\
(-0.693)\end{array}$ & $\begin{array}{c}-0.00234 \\
(-0.168)\end{array}$ & $\begin{array}{c}-0.00587 \\
(-0.583)\end{array}$ \\
\hline Filing Date & $\begin{array}{c}0.00863 \\
(0.481)\end{array}$ & $\begin{array}{l}0.0121 \\
(0.605)\end{array}$ & $\begin{array}{c}0.00925 \\
(0.517)\end{array}$ & $\begin{array}{l}0.0123 \\
(0.666)\end{array}$ & $\begin{array}{l}0.0143 \\
(0.697)\end{array}$ & $\begin{array}{l}0.0129 \\
(0.701)\end{array}$ & $\begin{array}{c}0.00905 \\
(0.517)\end{array}$ & $\begin{array}{l}0.0184 \\
(0.853)\end{array}$ & $\begin{array}{c}0.00953 \\
(0.543)\end{array}$ & $\begin{array}{c}0.00752 \\
(0.508)\end{array}$ & $\begin{array}{l}0.0433 \\
(1.197)\end{array}$ & $\begin{array}{c}0.00857 \\
(0.567)\end{array}$ \\
\hline Manager FE & Yes & No & Yes & Yes & No & Yes & Yes & No & Yes & Yes & No & Yes \\
\hline Stock FE & Yes & Yes & No & Yes & Yes & No & Yes & Yes & No & Yes & Yes & No \\
\hline Stock - Time FE & No & No & Yes & No & No & Yes & No & No & Yes & No & No & Yes \\
\hline Time FE & No & Yes & No & No & Yes & No & No & Yes & No & No & Yes & No \\
\hline Observations & 69,072 & 69,111 & 69,068 & 69,072 & 69,111 & 69,068 & 69,072 & 69,111 & 69,068 & 69,072 & 69,111 & 69,068 \\
\hline R-squared & 0.127 & 0.065 & 0.133 & 0.127 & 0.065 & 0.133 & 0.127 & 0.064 & 0.133 & 0.127 & 0.064 & 0.133 \\
\hline
\end{tabular}


Panel D: Central Brokers

Dependent Variable is the Log of Dollar Imbalances

\begin{tabular}{|c|c|c|c|c|c|c|c|c|c|c|c|c|}
\hline & (1) & (2) & (3) & (4) & (5) & (6) & (7) & (8) & (9) & (10) & (11) & (12) \\
\hline Strength of relationship proxy: & \multicolumn{3}{|c|}{$\begin{array}{c}\text { Ranking of Manager-Broker } \\
\text { Volume }\end{array}$} & \multicolumn{3}{|c|}{ Ranking of Revenue Share } & \multicolumn{3}{|c|}{$\begin{array}{c}\text { Frequency of Manager-Broker } \\
\text { Interaction }\end{array}$} & \multicolumn{3}{|c|}{ Broker - Manager Affiliation } \\
\hline Strong Relation & $\begin{array}{l}-0.336 \\
(-1.284)\end{array}$ & $\begin{array}{c}-0.0636 \\
(-0.0606)\end{array}$ & $\begin{array}{l}-0.275 \\
(-1.031)\end{array}$ & $\begin{array}{l}-0.138 \\
(-0.475)\end{array}$ & $\begin{array}{c}0.107 \\
(0.102)\end{array}$ & $\begin{array}{l}-0.0755 \\
(-0.259)\end{array}$ & $\begin{array}{l}-0.179 \\
(-0.645)\end{array}$ & $\begin{array}{c}0.0103 \\
(0.0116)\end{array}$ & $\begin{array}{l}-0.136 \\
(-0.490)\end{array}$ & $\begin{array}{c}-1.152^{* *} \\
(-2.477)\end{array}$ & $\begin{array}{c}-1.336 * * * \\
(-3.526)\end{array}$ & $\begin{array}{r}-1.226^{* * *} \\
(-3.014)\end{array}$ \\
\hline Strong Relation $\times$ Before & $\begin{array}{l}0.0687 \\
(0.287)\end{array}$ & $\begin{array}{l}0.0500 \\
(0.187)\end{array}$ & $\begin{array}{l}0.0431 \\
(0.179)\end{array}$ & $\begin{array}{c}-0.0166 \\
(-0.0731)\end{array}$ & $\begin{array}{l}-0.0400 \\
(-0.152)\end{array}$ & $\begin{array}{l}-0.0397 \\
(-0.169)\end{array}$ & $\begin{array}{l}-0.298 \\
(-1.075)\end{array}$ & $\begin{array}{c}-0.303 \\
(-0.976)\end{array}$ & $\begin{array}{l}-0.305 \\
(-1.084)\end{array}$ & $\begin{array}{c}1.800^{* * * *} \\
(3.876)\end{array}$ & $\begin{array}{c}1.742^{* * *} \\
(4.034)\end{array}$ & $\begin{array}{c}1.763^{* * *} \\
(3.762)\end{array}$ \\
\hline Strong Relation $\times$ Just Before & $\begin{array}{c}0.909 * * * \\
(2.644)\end{array}$ & $\begin{array}{c}1.362^{* * *} \\
(3.359)\end{array}$ & $\begin{array}{c}0.887^{* *} \\
(2.555)\end{array}$ & $\begin{array}{l}0.635^{*} \\
(1.891)\end{array}$ & $\begin{array}{c}1.149 * * * \\
(2.849)\end{array}$ & $\begin{array}{l}0.616^{*} \\
(1.818)\end{array}$ & $\begin{array}{c}0.691 * * \\
(2.222)\end{array}$ & $\begin{array}{c}1.098 * * * \\
(2.980)\end{array}$ & $\begin{array}{c}0.664^{* *} \\
(2.142)\end{array}$ & $\begin{array}{c}1.337 * * * \\
(4.527)\end{array}$ & $\begin{array}{c}1.273^{* * *} \\
(3.339)\end{array}$ & $\begin{array}{c}1.381 * * * \\
(4.237)\end{array}$ \\
\hline Strong Relation $\times$ Filing Day & $\begin{array}{c}0.252 \\
(0.454)\end{array}$ & $\begin{array}{c}1.784^{* *} \\
(2.075)\end{array}$ & $\begin{array}{c}0.255 \\
(0.460)\end{array}$ & $\begin{array}{c}0.00470 \\
(0.00798)\end{array}$ & $\begin{array}{l}1.619^{*} \\
(1.830)\end{array}$ & $\begin{array}{c}0.0139 \\
(0.0238)\end{array}$ & $\begin{array}{c}0.205 \\
(0.408)\end{array}$ & $\begin{array}{c}1.521^{* *} \\
(2.194)\end{array}$ & $\begin{array}{c}0.229 \\
(0.460)\end{array}$ & $\begin{array}{c}0.957 * * \\
(2.580)\end{array}$ & $\begin{array}{c}0.216 \\
(0.274)\end{array}$ & $\begin{array}{c}0.948 * * * \\
(2.780)\end{array}$ \\
\hline Before & $\begin{array}{l}-0.0621 \\
(-0.284)\end{array}$ & $\begin{array}{l}-0.158 \\
(-0.696)\end{array}$ & $\begin{array}{l}0.00889 \\
(0.0400)\end{array}$ & $\begin{array}{l}-0.0445 \\
(-0.207)\end{array}$ & $\begin{array}{l}-0.140 \\
(-0.625)\end{array}$ & $\begin{array}{l}0.0261 \\
(0.120)\end{array}$ & $\begin{array}{c}0.0170 \\
(0.0777)\end{array}$ & $\begin{array}{l}-0.0844 \\
(-0.371)\end{array}$ & $\begin{array}{l}0.0841 \\
(0.378)\end{array}$ & $\begin{array}{l}-0.0595 \\
(-0.280)\end{array}$ & $\begin{array}{l}-0.161 \\
(-0.721)\end{array}$ & $\begin{array}{l}0.00656 \\
(0.0303)\end{array}$ \\
\hline Just Before & $\begin{array}{c}-0.491 * * \\
(-2.016)\end{array}$ & $\begin{array}{c}-0.545^{* *} \\
(-2.149)\end{array}$ & $\begin{array}{l}-0.463^{*} \\
(-1.935)\end{array}$ & $\begin{array}{l}-0.420^{*} \\
(-1.742)\end{array}$ & $\begin{array}{l}-0.492^{*} \\
(-1.961)\end{array}$ & $\begin{array}{l}-0.392^{*} \\
(-1.657)\end{array}$ & $\begin{array}{l}-0.444^{*} \\
(-1.818)\end{array}$ & $\begin{array}{l}-0.478^{*} \\
(-1.877)\end{array}$ & $\begin{array}{l}-0.413^{*} \\
(-1.725)\end{array}$ & $\begin{array}{l}-0.262 \\
(-1.209)\end{array}$ & $\begin{array}{l}-0.174 \\
(-0.590)\end{array}$ & $\begin{array}{l}-0.238 \\
(-1.114)\end{array}$ \\
\hline Filing Date & $\begin{array}{l}0.0539 \\
(0.121)\end{array}$ & $\begin{array}{c}0.142 \\
(0.288)\end{array}$ & $\begin{array}{l}0.0621 \\
(0.139)\end{array}$ & $\begin{array}{c}0.129 \\
(0.290)\end{array}$ & $\begin{array}{c}0.182 \\
(0.372)\end{array}$ & $\begin{array}{c}0.135 \\
(0.305)\end{array}$ & $\begin{array}{c}0.0384 \\
(0.0906)\end{array}$ & $\begin{array}{c}0.244 \\
(0.483)\end{array}$ & $\begin{array}{c}0.0399 \\
(0.0940)\end{array}$ & $\begin{array}{l}0.0977 \\
(0.256)\end{array}$ & $\begin{array}{c}0.856 \\
(1.078)\end{array}$ & $\begin{array}{c}0.111 \\
(0.288)\end{array}$ \\
\hline Manager FE & Yes & No & Yes & Yes & No & Yes & Yes & No & Yes & Yes & No & Yes \\
\hline Stock FE & Yes & Yes & No & Yes & Yes & No & Yes & Yes & No & Yes & Yes & No \\
\hline Stock - Time FE & No & No & Yes & No & No & Yes & No & No & Yes & No & No & Yes \\
\hline Time FE & No & Yes & No & No & Yes & No & No & Yes & No & No & Yes & No \\
\hline Observations & 67,848 & 67,890 & 67,842 & 67,848 & 67,890 & 67,842 & 67,848 & 67,890 & 67,842 & 67,848 & 67,890 & 67,842 \\
\hline R-squared & 0.118 & 0.061 & 0.124 & 0.118 & 0.061 & 0.124 & 0.118 & 0.060 & 0.124 & 0.118 & 0.060 & 0.124 \\
\hline
\end{tabular}


Panel E: Peripheral Brokers

Dependent Variable is a Dummy identifying BUY trades

\begin{tabular}{|c|c|c|c|c|c|c|c|c|c|c|c|c|}
\hline & (1) & $(2)$ & (3) & (4) & (5) & (6) & (7) & (8) & (9) & $(10)$ & (11) & $(12)$ \\
\hline Strength of relationship proxy: & \multicolumn{3}{|c|}{$\begin{array}{c}\text { Ranking of Manager-Broker } \\
\text { Volume }\end{array}$} & \multicolumn{3}{|c|}{ Ranking of Revenue Share } & \multicolumn{3}{|c|}{$\begin{array}{c}\text { Frequency of Manager-Broker } \\
\text { Interaction }\end{array}$} & \multicolumn{3}{|c|}{ Broker - Manager Affiliation } \\
\hline Strong Relation & $\begin{array}{c}0.00980 \\
(0.741)\end{array}$ & $\begin{array}{c}0.00563 \\
(0.135)\end{array}$ & $\begin{array}{l}0.0100 \\
(0.747)\end{array}$ & $\begin{array}{c}-0.00430 \\
(-0.322)\end{array}$ & $\begin{array}{l}-0.00102 \\
(-0.0232)\end{array}$ & $\begin{array}{c}-0.00334 \\
(-0.254)\end{array}$ & $\begin{array}{l}0.0148 \\
(1.103)\end{array}$ & $\begin{array}{c}-0.00425 \\
(-0.119)\end{array}$ & $\begin{array}{l}0.0140 \\
(1.016)\end{array}$ & $\begin{array}{l}0.0427 \\
(1.232)\end{array}$ & $\begin{array}{c}-0.00483 \\
(-0.134)\end{array}$ & $\begin{array}{l}0.0424 \\
(1.405)\end{array}$ \\
\hline Strong Relation $\times$ Before & $\begin{array}{c}-0.00370 \\
(-0.263)\end{array}$ & $\begin{array}{c}-0.00422 \\
(-0.297)\end{array}$ & $\begin{array}{c}-0.00419 \\
(-0.298)\end{array}$ & $\begin{array}{c}0.00418 \\
(0.267)\end{array}$ & $\begin{array}{c}0.00322 \\
(0.214)\end{array}$ & $\begin{array}{c}0.00345 \\
(0.225)\end{array}$ & $\begin{array}{c}-0.00662 \\
(-0.386)\end{array}$ & $\begin{array}{c}-0.00466 \\
(-0.275)\end{array}$ & $\begin{array}{c}-0.00641 \\
(-0.375)\end{array}$ & $\begin{array}{l}-0.0255 \\
(-0.432)\end{array}$ & $\begin{array}{l}-0.0342 \\
(-0.737)\end{array}$ & $\begin{array}{l}-0.0292 \\
(-0.511)\end{array}$ \\
\hline Strong Relation $\times$ Just Before & $\begin{array}{l}0.0169 \\
(0.976)\end{array}$ & $\begin{array}{c}0.0293^{*} \\
(1.660)\end{array}$ & $\begin{array}{l}0.0186 \\
(1.090)\end{array}$ & $\begin{array}{l}0.0220 \\
(1.513)\end{array}$ & $\begin{array}{c}0.0360^{* *} \\
(2.039)\end{array}$ & $\begin{array}{l}0.0230 \\
(1.597)\end{array}$ & $\begin{array}{l}0.0120 \\
(0.626)\end{array}$ & $\begin{array}{l}0.0256 \\
(1.307)\end{array}$ & $\begin{array}{l}0.0137 \\
(0.723)\end{array}$ & $\begin{array}{l}0.0412 \\
(0.861)\end{array}$ & $\begin{array}{l}0.0163 \\
(0.303)\end{array}$ & $\begin{array}{l}0.0418 \\
(0.966)\end{array}$ \\
\hline Strong Relation $\times$ Filing Day & $\begin{array}{l}-0.0135 \\
(-0.394)\end{array}$ & $\begin{array}{l}0.0573 \\
(1.226)\end{array}$ & $\begin{array}{l}-0.0102 \\
(-0.299)\end{array}$ & $\begin{array}{l}0.0103 \\
(0.318)\end{array}$ & $\begin{array}{c}0.0800^{*} \\
(1.702)\end{array}$ & $\begin{array}{l}0.0120 \\
(0.372)\end{array}$ & $\begin{array}{l}-0.0360 \\
(-1.137)\end{array}$ & $\begin{array}{l}0.0287 \\
(0.648)\end{array}$ & $\begin{array}{l}-0.0342 \\
(-1.086)\end{array}$ & $\begin{array}{c}-0.00467 \\
(-0.109)\end{array}$ & $\begin{array}{l}-0.0462 \\
(-0.788)\end{array}$ & $\begin{array}{r}-0.00569 \\
(-0.138)\end{array}$ \\
\hline Before & $\begin{array}{l}-0.0141 \\
(-1.228)\end{array}$ & $\begin{array}{l}-0.0201 * \\
(-1.780)\end{array}$ & $\begin{array}{l}-0.0118 \\
(-1.028)\end{array}$ & $\begin{array}{l}-0.0158 \\
(-1.366)\end{array}$ & $\begin{array}{l}-0.0217^{*} \\
(-1.903)\end{array}$ & $\begin{array}{l}-0.0134 \\
(-1.167)\end{array}$ & $\begin{array}{l}-0.0135 \\
(-1.152)\end{array}$ & $\begin{array}{l}-0.0201 * \\
(-1.751)\end{array}$ & $\begin{array}{l}-0.0113 \\
(-0.968)\end{array}$ & $\begin{array}{l}-0.0148 \\
(-1.444)\end{array}$ & $\begin{array}{c}-0.0208^{* *} \\
(-2.013)\end{array}$ & $\begin{array}{l}-0.0125 \\
(-1.234)\end{array}$ \\
\hline Just Before & $\begin{array}{c}-0.0269 * * \\
(-2.297)\end{array}$ & $\begin{array}{c}-0.0227^{*} \\
(-1.705)\end{array}$ & $\begin{array}{c}-0.0274^{* *} \\
(-2.385)\end{array}$ & $\begin{array}{c}-0.0279 * * \\
(-2.447)\end{array}$ & $\begin{array}{c}-0.0240^{*} \\
(-1.882)\end{array}$ & $\begin{array}{c}-0.0282^{* *} \\
(-2.521)\end{array}$ & $\begin{array}{c}-0.0258^{* *} \\
(-2.115)\end{array}$ & $\begin{array}{l}-0.0208 \\
(-1.470)\end{array}$ & $\begin{array}{c}-0.0262^{* *} \\
(-2.191)\end{array}$ & $\begin{array}{c}-0.0225^{*} \\
(-1.745)\end{array}$ & $\begin{array}{l}-0.0144 \\
(-0.879)\end{array}$ & $\begin{array}{c}-0.0225^{*} \\
(-1.785)\end{array}$ \\
\hline Filing Date & $\begin{array}{c}0.00465 \\
(0.232)\end{array}$ & $\begin{array}{l}0.0111 \\
(0.464)\end{array}$ & $\begin{array}{c}0.00323 \\
(0.163)\end{array}$ & $\begin{array}{l}-0.00306 \\
(-0.159)\end{array}$ & $\begin{array}{l}0.00360 \\
(0.164)\end{array}$ & $\begin{array}{c}-0.00396 \\
(-0.209)\end{array}$ & $\begin{array}{l}0.0118 \\
(0.598)\end{array}$ & $\begin{array}{l}0.0237 \\
(0.878)\end{array}$ & $\begin{array}{l}0.0110 \\
(0.560)\end{array}$ & $\begin{array}{l}-0.000289 \\
(-0.0164)\end{array}$ & $\begin{array}{l}0.0336 \\
(0.879)\end{array}$ & $\begin{array}{l}-0.000549 \\
(-0.0309)\end{array}$ \\
\hline Manager FE & Yes & No & Yes & Yes & No & Yes & Yes & No & Yes & Yes & No & Yes \\
\hline Stock FE & Yes & Yes & No & Yes & Yes & No & Yes & Yes & No & Yes & Yes & No \\
\hline Stock - Time FE & No & No & Yes & No & No & Yes & No & No & Yes & No & No & Yes \\
\hline Time FE & No & Yes & No & No & Yes & No & No & Yes & No & No & Yes & No \\
\hline Observations & 27,673 & 27,726 & 27,669 & 27,673 & 27,726 & 27,669 & 27,673 & 27,726 & 27,669 & 27,673 & 27,726 & 27,669 \\
\hline R-squared & 0.136 & 0.062 & 0.140 & 0.136 & 0.062 & 0.140 & 0.136 & 0.061 & 0.140 & 0.136 & 0.061 & 0.140 \\
\hline
\end{tabular}


Panel F: Peripheral Brokers

Dependent Variable is the Log of Dollar Imbalances

\begin{tabular}{|c|c|c|c|c|c|c|c|c|c|c|c|c|}
\hline \multirow[b]{2}{*}{ Strength of relationship proxy: } & (1) & (2) & (3) & (4) & (5) & (6) & (7) & (8) & (9) & (10) & (11) & (12) \\
\hline & \multicolumn{3}{|c|}{$\begin{array}{c}\text { Ranking of Manager-Broker } \\
\text { Volume }\end{array}$} & \multicolumn{3}{|c|}{ Ranking of Revenue Share } & \multicolumn{3}{|c|}{$\begin{array}{c}\text { Frequency of Manager-Broker } \\
\text { Interaction }\end{array}$} & \multicolumn{3}{|c|}{ Broker - Manager Affiliation } \\
\hline Strong Relation & $\begin{array}{c}0.199 \\
(0.683)\end{array}$ & $\begin{array}{c}0.0374 \\
(0.0423)\end{array}$ & $\begin{array}{c}0.202 \\
(0.678)\end{array}$ & $\begin{array}{l}-0.216 \\
(-0.712)\end{array}$ & $\begin{array}{l}-0.161 \\
(-0.170)\end{array}$ & $\begin{array}{l}-0.194 \\
(-0.644)\end{array}$ & $\begin{array}{l}0.0380 \\
(0.138)\end{array}$ & $\begin{array}{l}-0.248 \\
(-0.314)\end{array}$ & $\begin{array}{l}0.0201 \\
(0.0726)\end{array}$ & $\begin{array}{c}0.785 \\
(0.992)\end{array}$ & $\begin{array}{c}0.0313 \\
(0.0373)\end{array}$ & $\begin{array}{r}0.850 \\
(1.057)\end{array}$ \\
\hline Strong Relation $\times$ Before & $\begin{array}{l}-0.0814 \\
(-0.262)\end{array}$ & $\begin{array}{l}-0.0776 \\
(-0.240)\end{array}$ & $\begin{array}{l}-0.0878 \\
(-0.284)\end{array}$ & $\begin{array}{c}0.107 \\
(0.331)\end{array}$ & $\begin{array}{l}0.0945 \\
(0.295)\end{array}$ & $\begin{array}{l}0.0920 \\
(0.288)\end{array}$ & $\begin{array}{l}-0.0795 \\
(-0.218)\end{array}$ & $\begin{array}{l}-0.0432 \\
(-0.112)\end{array}$ & $\begin{array}{l}-0.0751 \\
(-0.207)\end{array}$ & $\begin{array}{l}-1.116 \\
(-1.014)\end{array}$ & $\begin{array}{l}-1.213 \\
(-1.125)\end{array}$ & $\begin{array}{l}-1.230 \\
(-1.070)\end{array}$ \\
\hline Strong Relation $\times$ Just Before & $\begin{array}{c}0.143 \\
(0.403)\end{array}$ & $\begin{array}{c}0.418 \\
(1.160)\end{array}$ & $\begin{array}{c}0.170 \\
(0.486)\end{array}$ & $\begin{array}{c}0.235 \\
(0.826)\end{array}$ & $\begin{array}{c}0.550 \\
(1.543)\end{array}$ & $\begin{array}{c}0.244 \\
(0.868)\end{array}$ & $\begin{array}{c}0.209 \\
(0.508)\end{array}$ & $\begin{array}{c}0.503 \\
(1.223)\end{array}$ & $\begin{array}{c}0.237 \\
(0.584)\end{array}$ & $\begin{array}{c}0.764 \\
(0.561)\end{array}$ & $\begin{array}{c}0.369 \\
(0.244)\end{array}$ & $\begin{array}{c}0.811 \\
(0.591)\end{array}$ \\
\hline Strong Relation $\times$ Filing Day & $\begin{array}{l}-0.348 \\
(-0.433)\end{array}$ & $\begin{array}{c}1.140 \\
(1.051)\end{array}$ & $\begin{array}{l}-0.302 \\
(-0.379)\end{array}$ & $\begin{array}{c}0.232 \\
(0.310)\end{array}$ & $\begin{array}{c}1.717 \\
(1.630)\end{array}$ & $\begin{array}{c}0.242 \\
(0.328)\end{array}$ & $\begin{array}{l}-0.500 \\
(-0.685)\end{array}$ & $\begin{array}{c}0.842 \\
(0.881)\end{array}$ & $\begin{array}{l}-0.478 \\
(-0.662)\end{array}$ & $\begin{array}{c}0.247 \\
(0.271)\end{array}$ & $\begin{array}{l}-0.601 \\
(-0.456)\end{array}$ & $\begin{array}{c}0.177 \\
(0.180)\end{array}$ \\
\hline Before & $\begin{array}{l}-0.247 \\
(-0.908)\end{array}$ & $\begin{array}{c}-0.405 \\
(-1.504)\end{array}$ & $\begin{array}{l}-0.197 \\
(-0.731)\end{array}$ & $\begin{array}{l}-0.287 \\
(-1.060)\end{array}$ & $\begin{array}{l}-0.440 \\
(-1.648)\end{array}$ & $\begin{array}{l}-0.235 \\
(-0.879)\end{array}$ & $\begin{array}{l}-0.248 \\
(-0.894)\end{array}$ & $\begin{array}{c}-0.411 \\
(-1.509)\end{array}$ & $\begin{array}{l}-0.200 \\
(-0.728)\end{array}$ & $\begin{array}{l}-0.259 \\
(-1.062)\end{array}$ & $\begin{array}{l}-0.414^{*} \\
(-1.681)\end{array}$ & $\begin{array}{l}-0.209 \\
(-0.870)\end{array}$ \\
\hline Just Before & $\begin{array}{c}-0.519^{* *} \\
(-2.018)\end{array}$ & $\begin{array}{l}-0.443 \\
(-1.529)\end{array}$ & $\begin{array}{c}-0.525^{* *} \\
(-2.089)\end{array}$ & $\begin{array}{c}-0.534 * * \\
(-2.135)\end{array}$ & $\begin{array}{l}-0.464^{*} \\
(-1.678)\end{array}$ & $\begin{array}{c}-0.535^{* *} \\
(-2.195)\end{array}$ & $\begin{array}{l}-0.534 * \\
(-1.944)\end{array}$ & $\begin{array}{l}-0.443 \\
(-1.422)\end{array}$ & $\begin{array}{c}-0.540^{* *} \\
(-2.015)\end{array}$ & $\begin{array}{l}-0.482 \\
(-1.642)\end{array}$ & $\begin{array}{l}-0.328 \\
(-0.986)\end{array}$ & $\begin{array}{l}-0.481 * \\
(-1.717)\end{array}$ \\
\hline Filing Date & $\begin{array}{l}-0.0315 \\
(-0.0712)\end{array}$ & $\begin{array}{c}0.154 \\
(0.300)\end{array}$ & $\begin{array}{l}-0.0551 \\
(-0.126)\end{array}$ & $\begin{array}{l}-0.219 \\
(-0.514)\end{array}$ & $\begin{array}{l}-0.0309 \\
(-0.0644)\end{array}$ & $\begin{array}{l}-0.231 \\
(-0.550)\end{array}$ & $\begin{array}{c}0.0209 \\
(0.0466)\end{array}$ & $\begin{array}{c}0.323 \\
(0.542)\end{array}$ & $\begin{array}{l}0.00758 \\
(0.0170)\end{array}$ & $\begin{array}{c}-0.156 \\
(-0.389)\end{array}$ & $\begin{array}{c}0.588 \\
(0.720)\end{array}$ & $\begin{array}{l}-0.162 \\
(-0.412)\end{array}$ \\
\hline Manager FE & Yes & No & Yes & Yes & No & Yes & Yes & No & Yes & Yes & No & Yes \\
\hline Stock FE & Yes & Yes & No & Yes & Yes & No & Yes & Yes & No & Yes & Yes & No \\
\hline Stock - Time FE & No & No & Yes & No & No & Yes & No & No & Yes & No & No & Yes \\
\hline Time FE & No & Yes & No & No & Yes & No & No & Yes & No & No & Yes & No \\
\hline Observations & 26,950 & 27,006 & 26,944 & 26,950 & 27,006 & 26,944 & 26,950 & 27,006 & 26,944 & 26,950 & 27,006 & 26,944 \\
\hline R-squared & 0.129 & 0.057 & 0.133 & 0.129 & 0.058 & 0.133 & 0.129 & 0.057 & 0.133 & 0.129 & 0.057 & 0.133 \\
\hline
\end{tabular}




\section{Table 11. Club}

This table relates, for each investor/broker pair, the absolute value of dollar imbalances traded as a follower in a given quarter and the absolute value of dollar imbalances traded as an originator in the previous quarter, controlling for the lagged dependent variable. When computing the dependent variable, we consider all dollar imbalances traded as a follower (Columns 1-2); only the volumes traded in the same direction as the large trade (Columns 3-4); only the volumes traded in the same direction as the large trade and during the competition period, i.e. the time when the large trade has started but the originator is still trading (Columns 5-6); only the volumes traded in the same direction as the large trade and during the first week after the competition period (Columns 7-8). We require that the volume traded as an originator in the previous quarter to be greater than zero. T-stats based on robust standard errors, clustered at the manager level, are reported in parentheses. Asterisks denote significance levels $(* * *=1 \%, * *=5 \%, *=10 \%)$.

Dependent Variable is the absolute value of dollar imbalances traded as a follower in a given quarter

\begin{tabular}{|c|c|c|c|c|c|c|c|c|}
\hline \multirow{3}{*}{$\begin{array}{l}\text { Restriction on Imbalances: } \\
\text { Lagged Abs. Imbalances as ORIGINATOR }\end{array}$} & (1) & (2) & (3) & (4) & (5) & (6) & (7) & (8) \\
\hline & \multicolumn{2}{|c|}{ All Imbalances } & \multicolumn{2}{|c|}{$\begin{array}{c}\text { Same Direction of the Large } \\
\text { Trade }\end{array}$} & \multicolumn{2}{|c|}{$\begin{array}{l}\text { Same Direction / During } \\
\text { Competition Period }\end{array}$} & \multicolumn{2}{|c|}{$\begin{array}{c}\text { Same Direction / During Week } \\
1 \text { after Competition }\end{array}$} \\
\hline & $\begin{array}{l}0.0740 * * * \\
(13.72)\end{array}$ & $\begin{array}{c}0.104 * * * \\
(18.35)\end{array}$ & $\begin{array}{l}0.0546 * * * \\
(13.76)\end{array}$ & $\begin{array}{l}0.0700^{* * *} \\
(26.44)\end{array}$ & $\begin{array}{c}0.0131 * * * \\
(17.34)\end{array}$ & $\begin{array}{l}0.0117 * * * \\
(19.71)\end{array}$ & $\begin{array}{l}0.0479 * * * \\
(21.40)\end{array}$ & $\begin{array}{l}0.0502^{* * *} \\
(19.18)\end{array}$ \\
\hline Lagged Depended Variable & $\begin{array}{c}0.441 * * * \\
(16.73)\end{array}$ & $\begin{array}{c}0.282^{* * *} \\
(14.86)\end{array}$ & $\begin{array}{c}0.336^{* * *} \\
(9.637)\end{array}$ & $\begin{array}{c}0.170^{* * *} \\
(9.305)\end{array}$ & $\begin{array}{c}0.0905^{* * *} \\
(3.064)\end{array}$ & $\begin{array}{c}0.0344^{*} \\
(1.898)\end{array}$ & $\begin{array}{c}0.201^{* * *} \\
(8.367)\end{array}$ & $\begin{array}{c}0.120^{* * *} \\
(6.781)\end{array}$ \\
\hline Broker FE & Yes & No & Yes & No & Yes & No & Yes & No \\
\hline Manager FE & Yes & No & Yes & No & Yes & No & Yes & No \\
\hline Broker - Manager FE & No & Yes & No & Yes & No & Yes & No & Yes \\
\hline Observations & 38,786 & 38,350 & 38,786 & 38,350 & 38,786 & 38,350 & 38,786 & 38,350 \\
\hline R-squared & 0.446 & 0.495 & 0.355 & 0.424 & 0.187 & 0.233 & 0.277 & 0.320 \\
\hline
\end{tabular}




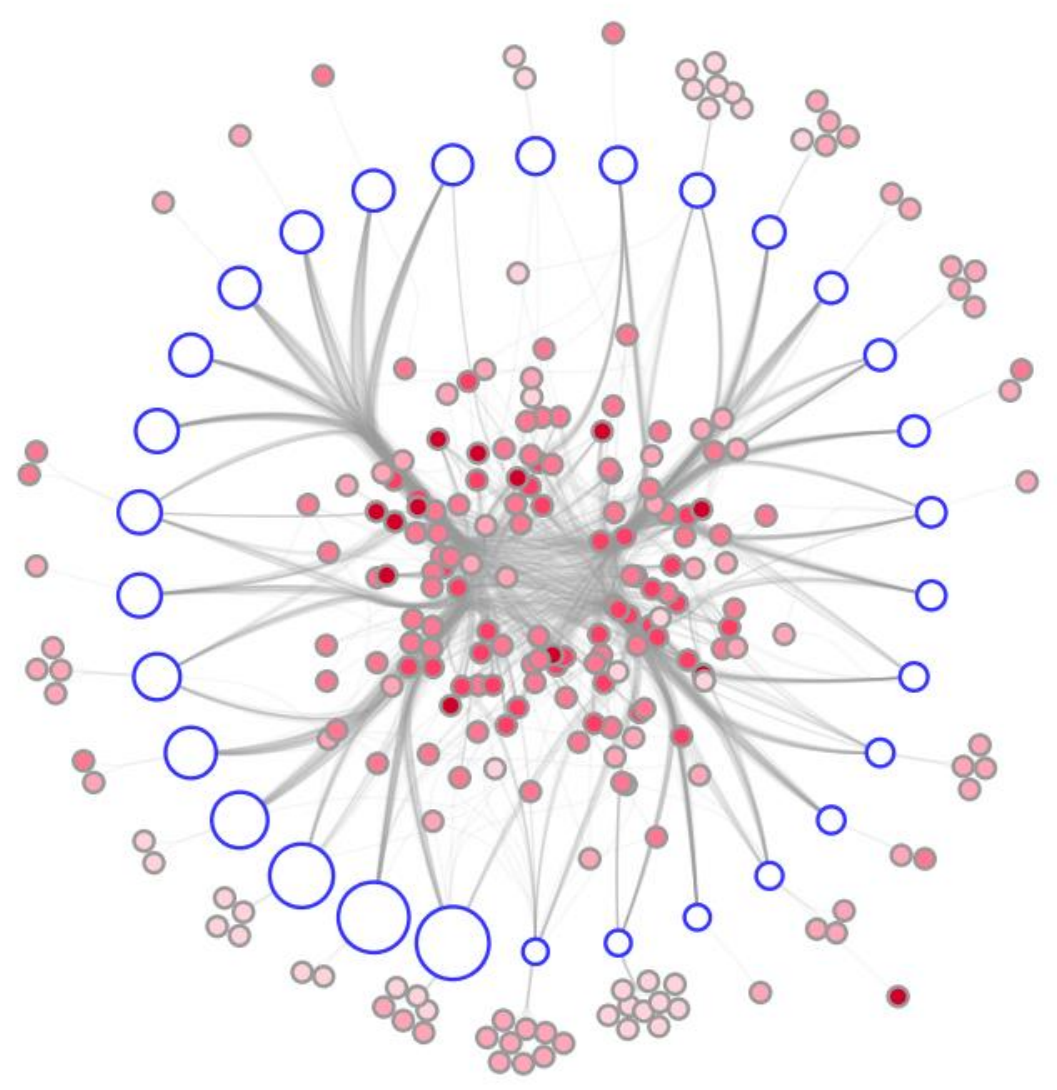

Figure 1

This figure depicts the network of managers (grey circles) and brokers (blue circles). The brokers are artificially set to stand in circle, their position and size depends on their measure of eigenvector centrality at the time in which the network was estimated. The managers outside of the broker circle interact only with one or two brokers in the period, the others stand in the middle, acting as a link between a broker and the others. The colors of the managers' circles depend on the dollar volume traded by the manager in the period: from a low volume (in pale pink - or a light grey) up to a very high volume (in intense red - or an intense grey). 


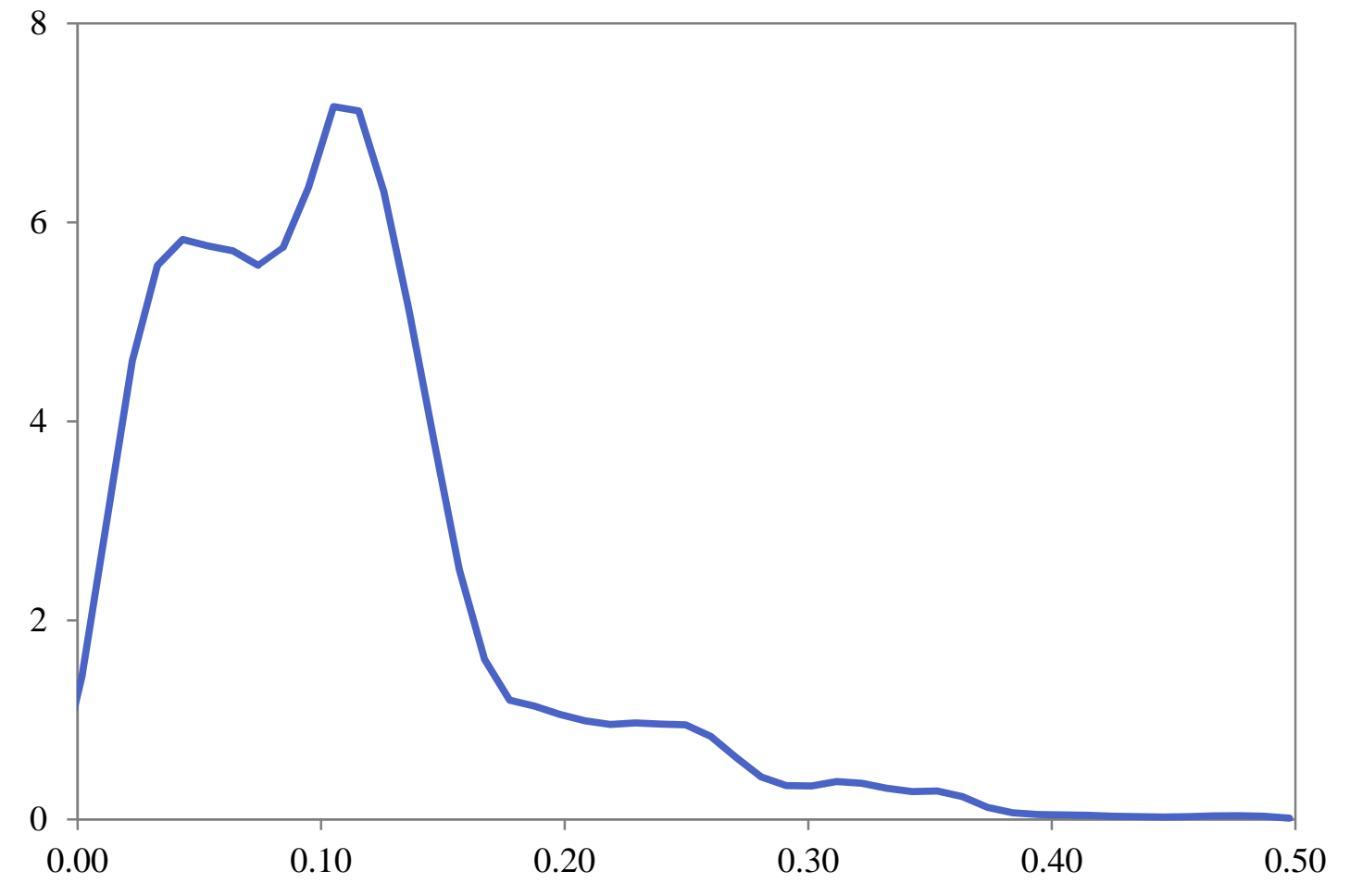

Figure 2

Kernel density estimation of eigenvector centrality over the whole time sample, i.e. July 1999 - December 2014. 


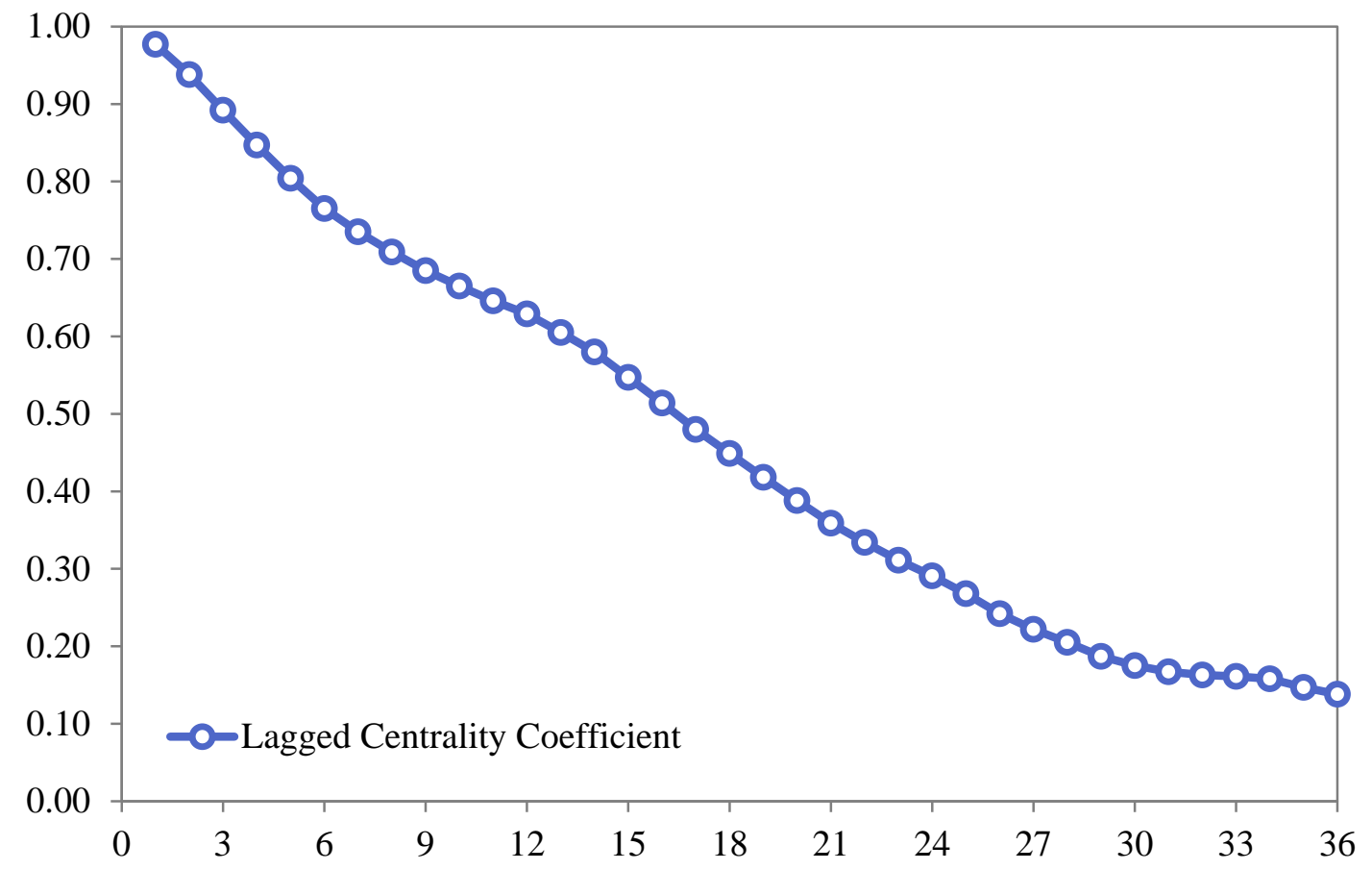

Figure 3

Eigenvector Centrality regressed on its lags, one at the time, starting from one month and moving up to 36 months. 


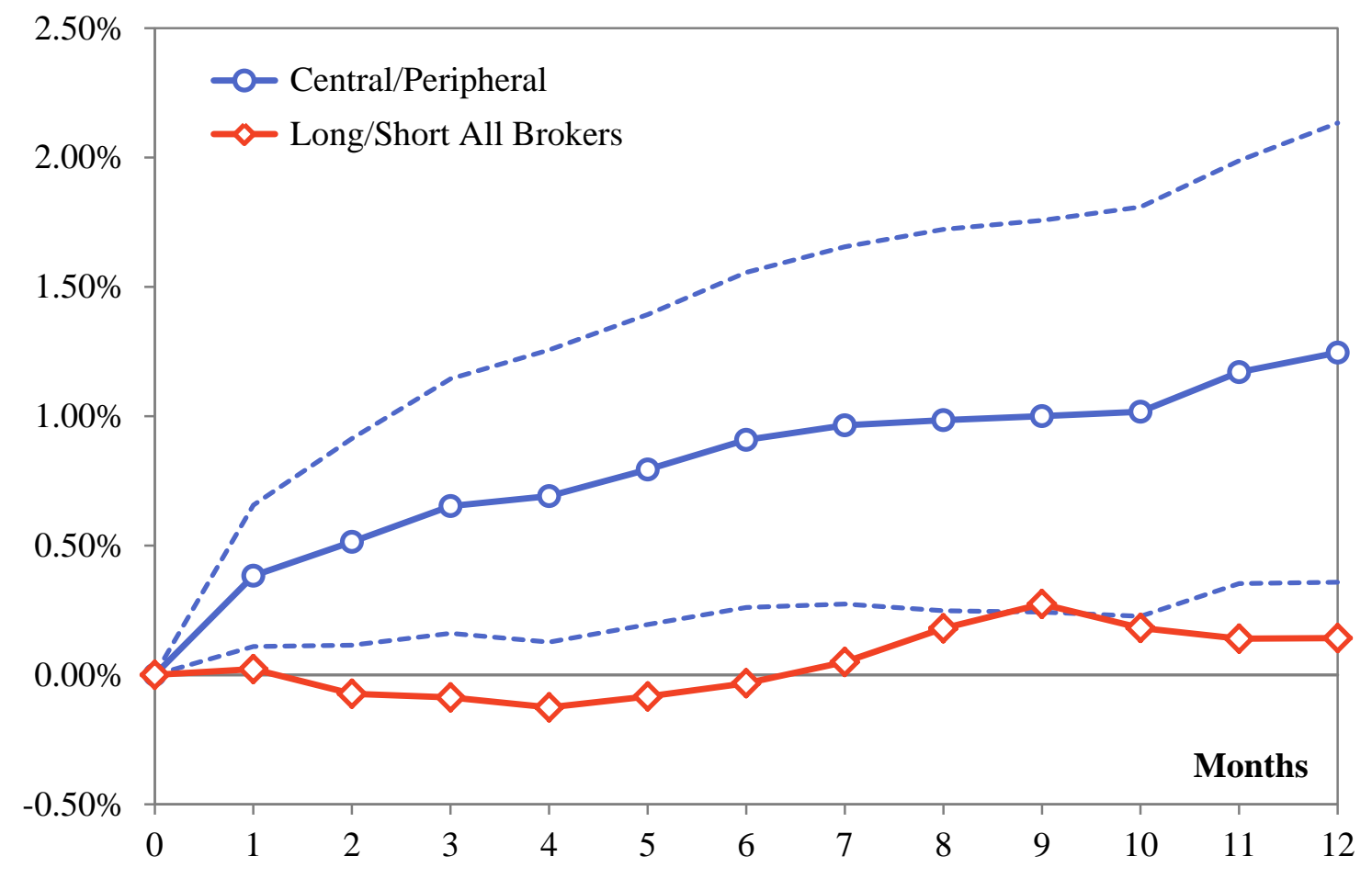

Figure 4

Cumulative return of the high-minus-low centrality portfolio built on month zero over the following twelve months (without rebalancing every three months), with a 95\% confidence interval (in blue - marked by the circles), together with the cumulative return of a generic long/short portfolio built on month zero (in red marked by triangles) by looking at the imbalances passing through the brokers, but without discriminating between central and peripheral brokers. 

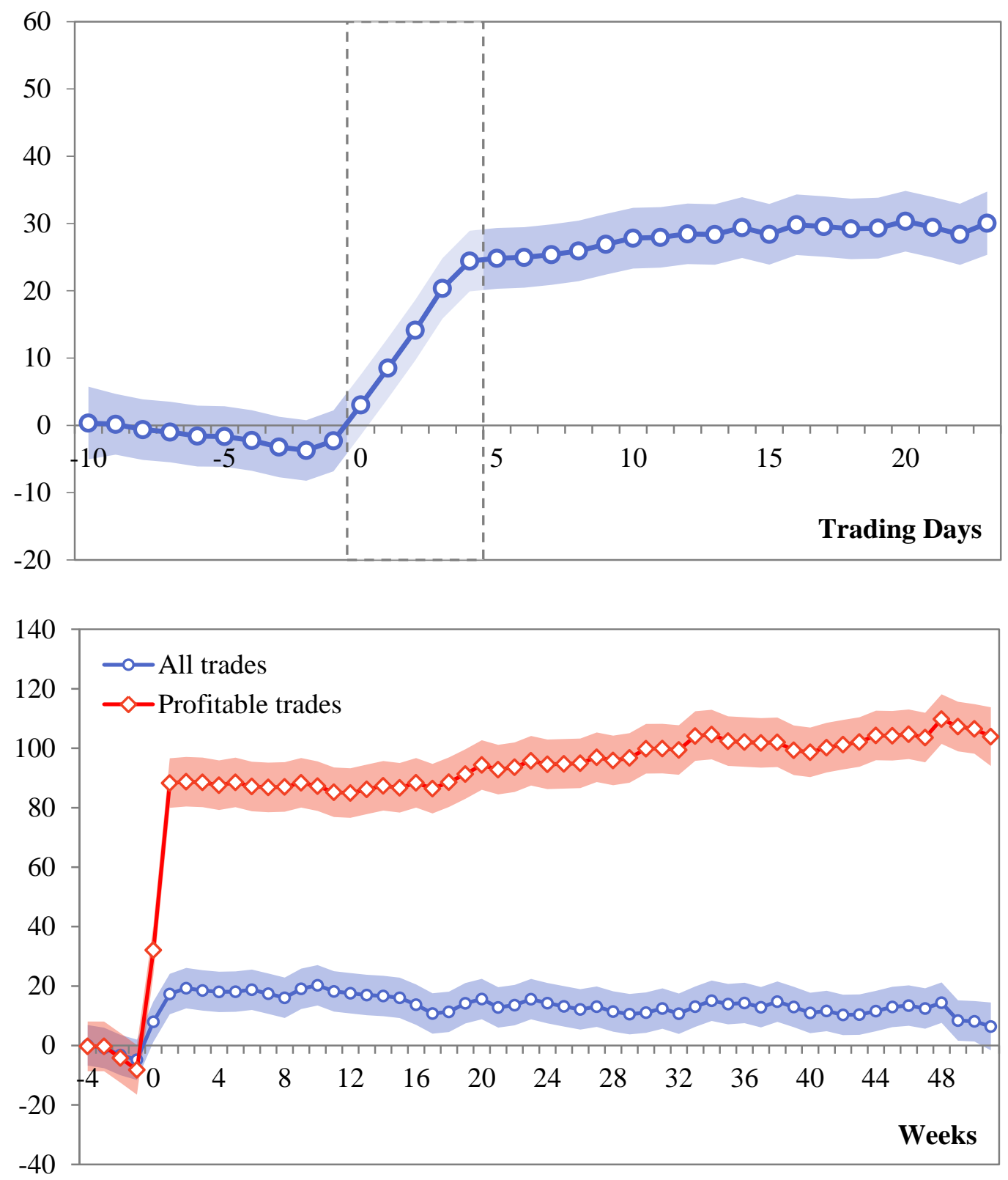

Figure 5

Cumulative abnormal return (in bps) of the stocks interested by a large trade before, during and after the week in which the large trade is identified (Week 0). Above: from day -10 to day 25; below: from week -4 to week 52. Profitable trades are all the trades in which the originator has a positive return during Week 0. 


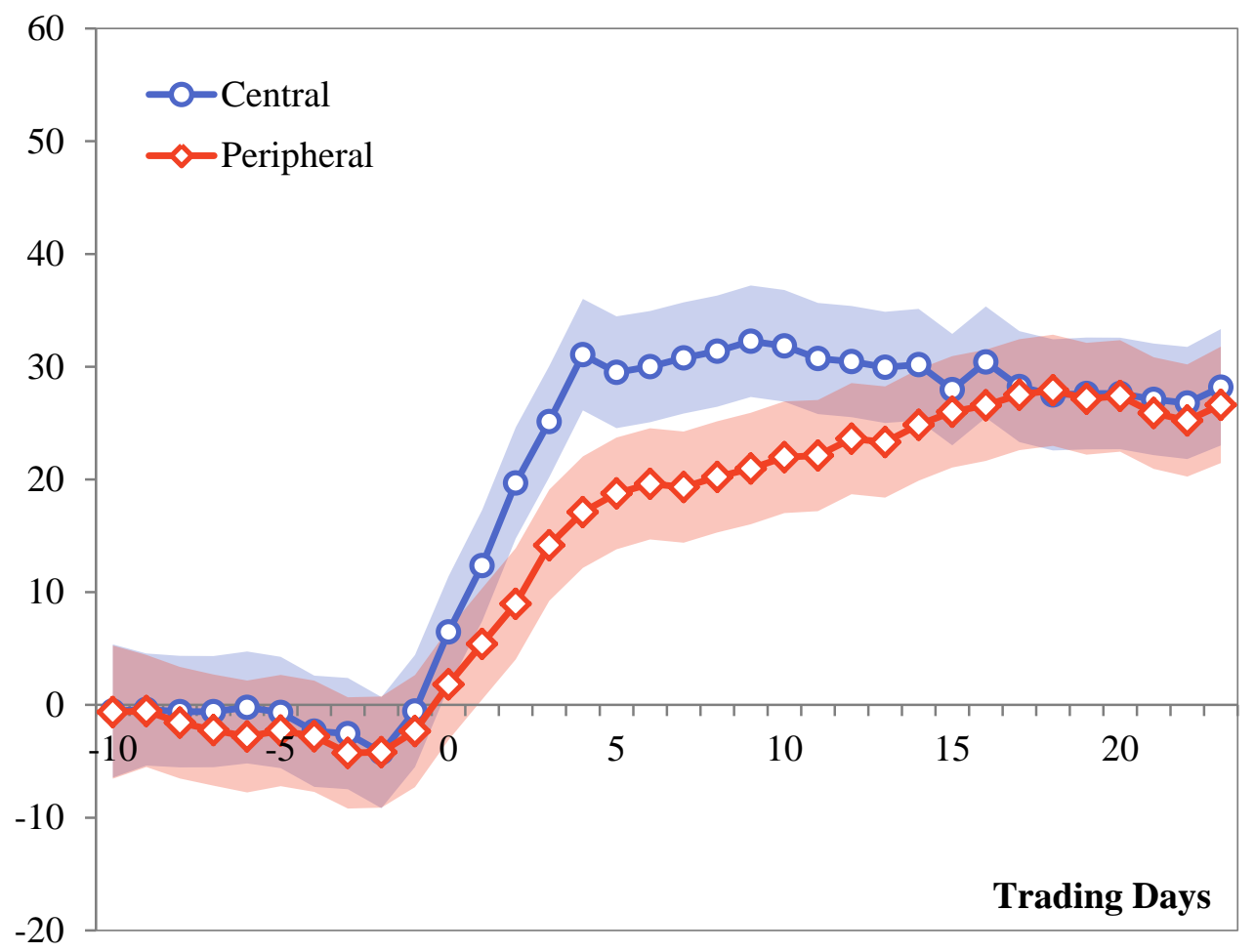

Figure 6

Cumulative abnormal return (in bps) of the stocks interested by a large trade before, during and after the week in which the large trade is identified (starting on day zero and ending on day four). We separate between large trades intermediated by central broker (in blue - marked by the triangles) and peripheral brokers (in red marked by the circles). Central broker here means all the brokers whose eigenvector centrality lies above the $60^{\text {th }}$ percentile of its distribution. The areas in blue and red are the standard errors: whenever they are not overlapping, it means that the difference between the central broker line and the peripheral broker line is significant at the $5 \%$ level. 


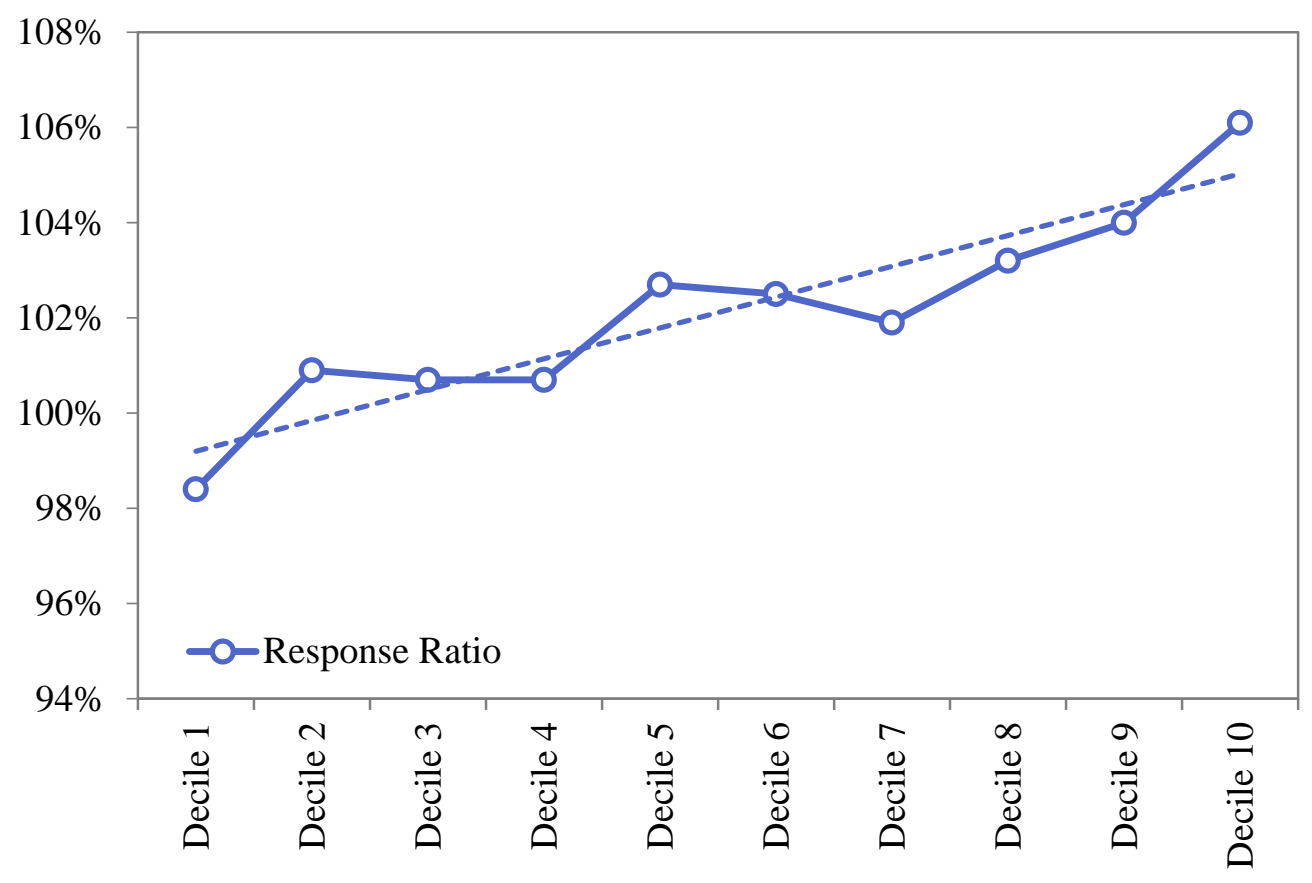

Figure 7

This figure plots the coefficients of a regression relating the Response Ratio (the ratio between the cumulative Fama-French 4 factors return on day 5 and on day 25) with the deciles of Eigenvector Centrality. 


\section{Online Appendix}

\section{Table A.1 Additional Controls}

This table regress the value-weighted trading performance at different time horizons (in basis points) on our centrality measures. Our database is collapsed at the broker/manager/ month level; we include additional controls with respect to the baseline regression: a proxy for the strength of the relationship between the manager and the broker intermediating the trade (Relationship Strength); the number of different clients of the broker (Number of Clients); a proxy of activeness of the brokers' clients, computed as the ratio of dollar volume traded by each client around earnings announcements on total volume, then averaged (volume weighting) across all the broker's clients (Client Activeness); number of hedge funds that are clients of the broker (Number of Hedge Funds Clients); client concentration of the broker, computed as the normalized Herfindahl Index of the volumes traded by each client (Adjusted Client Concentration); volume-weighted average of the centrality of the broker's clients -the centrality of the clients is computed as the Eigenvector Centrality of the broker, but without taking into account the strength of the link between traders and brokers (Client Centrality). All the measures are computed in a window of six months before the trade. T-stats based on robust standard errors, double-clustered at both the month and the manager level, are reported in parentheses. Asterisks denote significance levels $(* * *=1 \%, * *=5 \%, *=10 \%)$.

\begin{tabular}{|c|c|c|c|c|c|c|c|c|c|}
\hline & (1) & $(2)$ & (3) & (4) & (5) & (6) & (7) & (8) & (9) \\
\hline & \multicolumn{3}{|c|}{1 Day } & \multicolumn{3}{|c|}{5 Days } & \multicolumn{3}{|c|}{10 Days } \\
\hline Eig. Centrality & $\begin{array}{c}0.598^{* * *} \\
(3.085)\end{array}$ & $\begin{array}{c}0.509 * * * \\
(2.639)\end{array}$ & $\begin{array}{l}0.469 * * \\
(2.430)\end{array}$ & $\begin{array}{c}1.298^{* * *} \\
(2.636)\end{array}$ & $\begin{array}{l}1.098^{* *} \\
(2.215)\end{array}$ & $\begin{array}{l}1.125^{* *} \\
(2.298)\end{array}$ & $\begin{array}{l}1.659 * * \\
(2.465)\end{array}$ & $\begin{array}{l}1.298^{*} \\
(1.911)\end{array}$ & $\begin{array}{c}1.622 * * \\
(2.318)\end{array}$ \\
\hline Broker Volume & $\begin{array}{l}-0.0669 \\
(-0.420)\end{array}$ & $\begin{array}{l}0.276^{*} \\
(1.810)\end{array}$ & $\begin{array}{c}0.565 * * * \\
(3.671)\end{array}$ & $\begin{array}{c}0.587 \\
(1.331)\end{array}$ & $\begin{array}{c}1.245^{* * *} \\
(2.927)\end{array}$ & $\begin{array}{c}1.768^{* * *} \\
(4.101)\end{array}$ & $\begin{array}{l}0.880^{*} \\
(1.654)\end{array}$ & $\begin{array}{c}1.710^{* * *} \\
(3.316)\end{array}$ & $\begin{array}{c}2.352 * * * \\
(4.516)\end{array}$ \\
\hline Relationship Strength (Broker-Client Volume) & $\begin{array}{c}1.577 * * * \\
(6.023)\end{array}$ & $\begin{array}{c}0.890 * * * \\
(3.917)\end{array}$ & $\begin{array}{c}0.205 \\
(0.787)\end{array}$ & $\begin{array}{c}3.781 * * * \\
(6.299)\end{array}$ & $\begin{array}{c}2.419 * * * \\
(4.114)\end{array}$ & $\begin{array}{l}1.706^{* *} \\
(2.479)\end{array}$ & $\begin{array}{c}4.410^{* * *} \\
(4.579)\end{array}$ & $\begin{array}{c}3.323 * * * \\
(3.656)\end{array}$ & $\begin{array}{c}3.827 * * * \\
(3.982)\end{array}$ \\
\hline Number of Clients & $\begin{array}{c}-0.292 * * \\
(-2.423)\end{array}$ & $\begin{array}{l}-0.256^{* *} \\
(-2.219)\end{array}$ & $\begin{array}{c}-0.305^{* * *} \\
(-2.732)\end{array}$ & $\begin{array}{c}-0.440 \\
(-1.103)\end{array}$ & $\begin{array}{c}-0.282 \\
(-0.708)\end{array}$ & $\begin{array}{c}-0.412 \\
(-1.015)\end{array}$ & $\begin{array}{c}0.112 \\
(0.206)\end{array}$ & $\begin{array}{c}0.309 \\
(0.568)\end{array}$ & $\begin{array}{c}0.151 \\
(0.267)\end{array}$ \\
\hline Client Activeness & $\begin{array}{c}-0.114 \\
(-0.694)\end{array}$ & $\begin{array}{c}-0.128 \\
(-0.821)\end{array}$ & $\begin{array}{l}-0.0518 \\
(-0.318)\end{array}$ & $\begin{array}{c}1.062^{* * *} \\
(2.640)\end{array}$ & $\begin{array}{c}0.991 * * \\
(2.483)\end{array}$ & $\begin{array}{c}0.925^{* *} \\
(2.160)\end{array}$ & $\begin{array}{c}2.555^{* * *} \\
(4.096)\end{array}$ & $\begin{array}{c}2.423 * * * \\
(3.951)\end{array}$ & $\begin{array}{c}2.168^{* * *} \\
(3.445)\end{array}$ \\
\hline Number of Hedge Funds Clients & $\begin{array}{c}0.701 * * * \\
(4.360)\end{array}$ & $\begin{array}{c}0.533^{* * *} \\
(3.306)\end{array}$ & $\begin{array}{c}0.505^{* * *} \\
(3.188)\end{array}$ & $\begin{array}{c}0.975^{* *} \\
(2.390)\end{array}$ & $\begin{array}{c}0.674 \\
(1.635)\end{array}$ & $\begin{array}{c}0.582 \\
(1.377)\end{array}$ & $\begin{array}{c}0.640 \\
(0.986)\end{array}$ & $\begin{array}{c}0.167 \\
(0.255)\end{array}$ & $\begin{array}{c}0.126 \\
(0.193)\end{array}$ \\
\hline Adjusted Client Concentration & $\begin{array}{c}0.115 \\
(0.714)\end{array}$ & $\begin{array}{l}-0.124 \\
(-0.789)\end{array}$ & $\begin{array}{l}-0.259 \\
(-1.565)\end{array}$ & $\begin{array}{c}0.270 \\
(0.657)\end{array}$ & $\begin{array}{l}-0.196 \\
(-0.504)\end{array}$ & $\begin{array}{l}-0.391 \\
(-1.015)\end{array}$ & $\begin{array}{c}0.452 \\
(0.727)\end{array}$ & $\begin{array}{l}-0.0896 \\
(-0.153)\end{array}$ & $\begin{array}{l}-0.364 \\
(-0.598)\end{array}$ \\
\hline Client Centrality (not-weighted) & $\begin{array}{c}0.755^{* * *} \\
(3.927)\end{array}$ & $\begin{array}{c}0.544 * * * \\
(2.901)\end{array}$ & $\begin{array}{c}0.513 * * * \\
(2.664)\end{array}$ & $\begin{array}{l}0.808^{*} \\
(1.665)\end{array}$ & $\begin{array}{c}0.637 \\
(1.336)\end{array}$ & $\begin{array}{c}0.637 \\
(1.366)\end{array}$ & $\begin{array}{c}0.331 \\
(0.510)\end{array}$ & $\begin{array}{l}0.0828 \\
(0.126)\end{array}$ & $\begin{array}{c}-0.0382 \\
(-0.0583)\end{array}$ \\
\hline Average Trade Size & $\begin{array}{c}-2.191^{* * *} \\
(-13.45)\end{array}$ & $\begin{array}{c}-2.410^{* * *} \\
(-15.53)\end{array}$ & $\begin{array}{c}-3.048 * * * \\
(-16.76)\end{array}$ & $\begin{array}{c}-4.494^{* * *} \\
(-11.85)\end{array}$ & $\begin{array}{c}-5.065^{* * *} \\
(-13.56)\end{array}$ & $\begin{array}{c}-5.915^{* * *} \\
(-13.75)\end{array}$ & $\begin{array}{c}-5.145^{* * *} \\
(-8.429)\end{array}$ & $\begin{array}{c}-5.705^{* * *} \\
(-9.396)\end{array}$ & $\begin{array}{c}-6.826 * * * \\
(-11.48)\end{array}$ \\
\hline Time FE & Yes & Yes & No & Yes & Yes & No & Yes & Yes & No \\
\hline Manager FE & No & Yes & No & No & Yes & No & No & Yes & No \\
\hline Manager-Time FE & No & No & Yes & No & No & Yes & No & No & Yes \\
\hline Observations & 603,030 & 603,021 & 593,467 & 599,310 & 599,303 & 589,780 & 591,569 & 591,561 & 582,051 \\
\hline R-squared & 0.003 & 0.011 & 0.128 & 0.002 & 0.007 & 0.132 & 0.002 & 0.006 & 0.138 \\
\hline
\end{tabular}




\section{Table A.2 Execution}

This table regresses the value-weighted trading performance, robust to execution costs, at different time horizons (in basis points) on our centrality measures. Columns (1)-(2) present the results when we replace the actual execution price with the opening price of the day to compute the trading performance; in Columns (3)(4) we use the value-weighted average daily price as a replacement and in Columns (5)-(6) we use the closing price of the day. Our database here is collapsed at the broker/manager/stock/month level, thus we are able to add manager/stock/time fixed effects. We include as a control the natural logarithm of the dollar trade volume intermediated by each broker in the last six months and the average dollar volume traded (in the stock) by the manager with the broker in the month in which performance is assessed. The dependent variable is our eigenvector centrality measure. T-stats based on robust standard errors, double-clustered at both the month and the manager level, are reported in parentheses. Asterisks denote significance levels $(* * *=1 \%, * *=5 \%$, $*=10 \%)$.

Dependent Variable: Value-weighted trading performance

\begin{tabular}{|c|c|c|c|c|c|c|}
\hline & (1) & (2) & (3) & (4) & (5) & (6) \\
\hline & \multicolumn{2}{|c|}{ Opening Price } & \multicolumn{2}{|c|}{ Average Daily Price } & \multicolumn{2}{|c|}{ Closing Price } \\
\hline & 5 Days & 10 Days & 5 Days & 10 Days & 5 Days & 10 Days \\
\hline Eig. Centrality & $\begin{array}{c}1.573^{* * *} \\
(3.754)\end{array}$ & $\begin{array}{c}2.010^{* * *} \\
(2.832)\end{array}$ & $\begin{array}{c}0.888^{* * *} \\
(2.930)\end{array}$ & $\begin{array}{c}1.334^{* *} \\
(2.099)\end{array}$ & $\begin{array}{c}0.852^{* *} \\
(2.023)\end{array}$ & $\begin{array}{l}1.372 * \\
(1.696)\end{array}$ \\
\hline Broker Volume & $\begin{array}{l}-1.363 \\
(-1.523)\end{array}$ & $\begin{array}{l}-1.724^{*} \\
(-1.852)\end{array}$ & $\begin{array}{l}-1.227^{*} \\
(-1.699)\end{array}$ & $\begin{array}{c}-1.687 * * \\
(-2.101)\end{array}$ & $\begin{array}{l}-1.293^{*} \\
(-1.749)\end{array}$ & $\begin{array}{c}-1.787 * * \\
(-2.076)\end{array}$ \\
\hline Average Trade Size & $\begin{array}{c}2.702^{* * *} \\
(7.847)\end{array}$ & $\begin{array}{c}2.881 * * * \\
(9.778)\end{array}$ & $\begin{array}{c}0.703 * * * \\
(3.745)\end{array}$ & $\begin{array}{c}0.991 * * * \\
(4.687)\end{array}$ & $\begin{array}{l}0.0896 \\
(0.523)\end{array}$ & $\begin{array}{c}0.441 * * \\
(2.017)\end{array}$ \\
\hline Manager-Stock-Time FE & Yes & Yes & Yes & Yes & Yes & Yes \\
\hline Observations & $17,623,409$ & $17,365,029$ & $17,621,475$ & $17,363,402$ & $17,620,270$ & $17,362,802$ \\
\hline R-squared & 0.397 & 0.430 & 0.389 & 0.427 & 0.381 & 0.422 \\
\hline
\end{tabular}




\section{Table A.3 Large Trade Profits}

This table relates the probability of a positive return over five trading days (the dependent variable) for a manager (who is required to be an Hedge Fund) executing a large net volume with a specific broker on a stock, with respect to non-large net volume executions. Large net volumes over a five trading days window are captured by the dummy variable Large Trade and are defined as net volumes (i.e. imbalances) larger or equal than the 75th percentile (or the 90th percentile) of the imbalances distribution estimated in the previous six months. All the imbalances are scaled by the trading volume in CRSP. We include as a control the natural logarithm of the market capitalization and the Amihud illiquidity measure for the stock, estimated over the previous twelve months. T-stats are reported in parentheses. Asterisks denote significance levels $(* * *=1 \%$, $* *=5 \%, *=10 \%)$.

Dependent Variable: Dummy that identifies positive profits

\begin{tabular}{|c|c|c|c|c|}
\hline & (1) & (2) & (3) & (4) \\
\hline & \multicolumn{2}{|c|}{ P75 } & \multicolumn{2}{|c|}{ P90 } \\
\hline Large Trade & $\begin{array}{c}0.503^{* * *} \\
(218.3)\end{array}$ & $\begin{array}{c}0.505^{* * *} \\
(219.5)\end{array}$ & $\begin{array}{c}0.690 * * * \\
(146.5)\end{array}$ & $\begin{array}{c}0.691 * * * \\
(147.1)\end{array}$ \\
\hline Market Cap & $\begin{array}{c}0.00912^{* * *} \\
(26.07)\end{array}$ & & $\begin{array}{c}0.0104 * * * \\
(29.92)\end{array}$ & \\
\hline Amihud Illiquidity & $\begin{array}{c}-0.408^{* * *} \\
(-7.013)\end{array}$ & & $\begin{array}{c}-0.446 * * * \\
(-7.797)\end{array}$ & \\
\hline Constant & $\begin{array}{c}2.026^{* * *} \\
(259.8)\end{array}$ & $\begin{array}{c}2.228^{* * *} \\
(3,489)\end{array}$ & $\begin{array}{c}2.032 * * * \\
(261.3)\end{array}$ & $\begin{array}{c}2.264 * * * \\
(3,674)\end{array}$ \\
\hline Observations & $34,950,742$ & $35,236,163$ & $34,950,742$ & $35,236,163$ \\
\hline
\end{tabular}




\section{Table A.4 Unusual Stocks}

The table reports coefficient estimates of least square regressions relating the value-weighted trading performance at different time horizons (in basis points) and our centrality measures. Our database here is collapsed at the broker/manager/stock/month level, thus we are able to add stock and stock/time fixed effects. In these test we interact our centrality measure with a dummy (unusual) that flags the stocks we deem as unusual for the broker. We compute for each stock/broker pair the dollar volume in the stock intermediated by the broker in the previous six months, as a percentage of the total dollar volume intermediated by the broker. We then adjust this to take into account the total number of stocks traded by the broker in the same period. Finally, we consider as unusual stocks for a broker all the stocks whose adjusted percentage volume lies below the tenth percentile of its distribution across all stocks/months in our sample. We include as a control the natural logarithm of the dollar trade volume intermediated by each broker in the last six months and the average dollar volume traded (in the stock) by the manager with the broker in the month in which performance is assessed. T-stats based on robust standard errors, double-clustered at both the month and the manager level, are reported in parentheses. Asterisks denote significance levels $(* * *=1 \%, * *=5 \%, *=10 \%)$.

Dependent variable: Value-weighted trading performance

\begin{tabular}{|c|c|c|c|c|c|c|}
\hline \multirow[b]{3}{*}{ Centrality $\times$ Unusual } & (1) & (2) & (3) & (4) & (5) & (6) \\
\hline & \multicolumn{2}{|c|}{1 Days } & \multicolumn{2}{|c|}{5 Days } & \multicolumn{2}{|c|}{10 Days } \\
\hline & $\begin{array}{c}0.515^{* *} \\
(2.015)\end{array}$ & $\begin{array}{l}0.415^{*} \\
(1.854)\end{array}$ & $\begin{array}{c}1.904^{* *} \\
(2.119)\end{array}$ & $\begin{array}{l}1.695^{*} \\
(1.910)\end{array}$ & $\begin{array}{c}2.995^{* *} \\
(2.525)\end{array}$ & $\begin{array}{c}2.825^{* *} \\
(2.404)\end{array}$ \\
\hline Unusual Stocks & $\begin{array}{l}-0.653 \\
(-0.745)\end{array}$ & $\begin{array}{l}-0.433 \\
(-0.571)\end{array}$ & $\begin{array}{l}-4.692^{*} \\
(-1.968)\end{array}$ & $\begin{array}{l}-4.325^{*} \\
(-1.915)\end{array}$ & $\begin{array}{c}-7.741 * * \\
(-2.205)\end{array}$ & $\begin{array}{c}-7.010^{* *} \\
(-2.100)\end{array}$ \\
\hline Centrality & $\begin{array}{c}0.457^{* *} \\
(2.316)\end{array}$ & $\begin{array}{c}0.236 \\
(1.224)\end{array}$ & $\begin{array}{c}1.009^{* * *} \\
(2.711)\end{array}$ & $\begin{array}{c}0.716^{* *} \\
(2.277)\end{array}$ & $\begin{array}{c}1.149 \\
(1.601)\end{array}$ & $\begin{array}{c}0.622 \\
(1.398)\end{array}$ \\
\hline Broker Volume & $\begin{array}{l}-0.213 \\
(-1.110)\end{array}$ & $\begin{array}{l}-0.218 \\
(-1.327)\end{array}$ & $\begin{array}{l}-0.998^{*} \\
(-1.683)\end{array}$ & $\begin{array}{c}-1.255^{* *} \\
(-2.129)\end{array}$ & $\begin{array}{l}-1.584 * \\
(-1.930)\end{array}$ & $\begin{array}{c}-1.830^{* *} \\
(-2.319)\end{array}$ \\
\hline Average Trade Volume & $\begin{array}{c}0.310^{* * *} \\
(3.030)\end{array}$ & $\begin{array}{c}0.126 \\
(1.297)\end{array}$ & $\begin{array}{l}0.438^{*} \\
(1.960)\end{array}$ & $\begin{array}{l}0.0932 \\
(0.386)\end{array}$ & $\begin{array}{c}0.704 * * \\
(1.989)\end{array}$ & $\begin{array}{c}0.419 \\
(1.224)\end{array}$ \\
\hline Manager FE & No & Yes & No & Yes & No & Yes \\
\hline Stock-Time FE & Yes & Yes & Yes & Yes & Yes & Yes \\
\hline Observations & $22,472,436$ & $22,472,433$ & $22,339,563$ & $22,339,561$ & $22,071,583$ & $22,071,580$ \\
\hline R-squared & 0.039 & 0.040 & 0.044 & 0.045 & 0.049 & 0.050 \\
\hline
\end{tabular}

